\title{
Combining Proto-Scandinavian loanword strata in South Saami with the Early Iron Age archaeological material of Jämtland and Dalarna, Sweden'
}

In this article, I will examine South Saami prehistory from the perspectives of archaeology and historical lexicology. I will present a theoretical model that can be applied to a multidisciplinary research that uses methodologies from both the sciences and test it using South Saami material. My linguistic data consists of North-West Germanic and Early Proto-Scandinavian loanwords in South Saami. These loanword strata can be dated to 1-550 CE. I will make an inventory of the semantic categories of the words in the loanword strata to see from which domains words were borrowed. I will also examine the prominent individual words that might have significance as intercultural markers. The archaeological material used in the research includes hunting ground graves, iron manufacturing sites and dwelling sites in Dalarna and Jämtland, Sweden. I will consider remain types, artefact finds and remain structures dated to 1-550 CE. Only those sites that have been excavated will be included in the data. I will correlate the lexical finds with the archaeological find groups in order to examine what the datasets together reveal about contacts between the South Saami and Scandinavian speakers. The combination of archaeological and lexical research offers new advantages and perspectives to the study of prehistory. The study brings new evidence for the prior hypothesis about South Saami speakers as domestic animal herders. The combination of these sciences also reveals that the earliest hunting ground graves should be considered to have belonged to a non-Saami speaking Paleo-European people. 
1. Introduction

1.1. Archaeological and linguistic background of the research

1.2. The datasets

2. The theoretical model

2.1. Perspectives on categorization in linguistics and archaeology

2.2. A hypothetical example of the use of the model

3. The lexical material

3.1. Semantic categories

3.2. Language and cultural contacts in the light of the loanwords

4. The archaeological material

4.1. Remains in the hunting grounds

4.2. The archeological categories and find groups

4.3. Summary

5. Combining the lexical and archaeological material
5.1. The uncorrelative semantic and archaeological categories

5.2. The correlative semantic and archaeological categories

5.3. Problematic categories, find groups and lexical finds

5.4. Summary

6. New perspectives on the Early Iron Age in the hunting grounds in Jämtland and Dalarna

6.1. Domestic animals among Southern ProtoSaami speakers

6.2. Reindeer pastoralism

6.3. Southern Proto-Saami contacts with Paleo-European of central Scandinavia

6.4. Iron manufacture

7. Conclusions

Appendix 1

Appendix 2

Appendix 3

Appendix 4

\section{Introduction}

In this article, I will examine South Saami prehistory from the perspectives of archaeology and historical lexicology, which both seek to study the human past. I have sketched a new theoretical model applicable to multidisciplinary research that uses methodologies from both of these sciences. I will test the model using material connected to the South Saami language and its speakers. The combination of archaeology and historical lexicology provides a wider and more detailed picture of the past: the disciplines reveal different prehistoric phenomena and different aspects of the same phenomena. My interest in this article lies in studying the contacts between the predecessors of South Saami and Scandinavian speakers in the Early Iron Age (1-550 CE). I will try to answer the question of what the combination of archaeology and historical lexicology can tell us about South Saami prehistory concerning the contacts between the two language groups. 


\section{I.I. Archaeological and linguistic background of the research}

In recent years, the consensus that archaeologists and linguists had constructed in the 1980s about the immigration and diffusion of Finnic and Saami speaking groups has come under criticism. Late Neolithic cultures in Finland were previously thought to belong to Finnish- and Saamispeaking groups (e.g. Carpelan 1999: 258; Koivulehto 1999c). New results in linguistics strongly indicate that these cultures are too old to be Finnicor Saami-speaking (e.g. J. Häkkinen 2010a). Instead, it has been proposed that the Finnic and Saami languages arrived in the Baltic sea area around the end of the Bronze Age or beginning of the Iron Age (50o BCE) (J. Häkkinen 2010b: 57-58; see also e.g. Parpola 2017: 259). The modern understanding is that the Proto-Saami language has its Urheimat in the southern parts of Karelia and Finland, from whence it spread to other parts of Fennoscandia, disintegrating into dialects (e.g. Aikio 2006: 43-47; Aikio 2012: 77; J. Häkkinen 2010b: 57).

Even though the expansion of Finnish and Saami languages has been dated much later than traditionally believed, the immigration of Saami whether it was the language or its speakers - into inland Scandinavia is suggested, especially by linguists, to have occurred earlier than previously thought. Some archaeologists in Sweden propose that the ancestors of South Saami had already arrived in inland Scandinavia by the beginning of the Common Era, or even earlier (e.g. Zachrisson 1997, 2009; Hansen \& Olsen 2006: 103). Some researchers do not acknowledge the presence of the Saami in the inland areas before a very late dating (e.g. Stedingk \& Baudou 2006). Nevertheless, since the 1970s, the general view seems to be that it is not important to ask when or from where the Saami immigrated into Scandinavia (Simonsen 1973: 181-182) but how the Saami ethnicity was adopted (Storli 1986, 46). Since the 1980s, archaeologists (e.g. Zachrisson 1997) have discussed the emergence of the Saami ethnicity as having taken place in the Iron Age.

However, the Saami ethnicity is not the same thing as the Saami language, although they are deeply connected. The question of when and from where the language came to Central Scandinavia and how it affected the emergence of the Saami ethnicity has not been discussed by archaeologists to any significant extent (although see Gjerde 2016: 54), even though language should be an important factor in creating ethnic identity. In this article, I speak of languages and language speakers, not ethnicity, ethnic 
identity or ethnic groups. I will address the question of language, material culture and ethnicity elsewhere in my $\mathrm{PhD}$ work. (On Saami ethnicity in archaeology, see e.g. Gjerde 2016: 29-33; Hansen \& Olsen 2006, 29-44.)

Linguists, in turn, have traditionally viewed the expansion of the Saami languages as having reached inland Scandinavia around 800-1000 CE (e.g. Saarikivi 2011: 114). J. Häkkinen (2010b: 59), Heikkilä (2011: 68-69) and Aikio (2012: 77-78) have suggested, based on Saami toponyms that have been borrowed from Proto-Scandinavian, that the predecessor of the modern South Saami language must have already been in Scandinavia around 400-500 CE at the latest. I am inclined to support this hypothesis.

The hypothesis is, however, problematic from the perspective of archaeological interpretation. The very early archaeological remains from before the Common Era or right around the beginning of the Common Era that are suggested by archaeologists to have belonged to the ancestors of the South Saami people may very well have belonged to them, but these ancestors would not have spoken any form of Saami language, as it arrived slightly later. Here, I will present a hypothesis of who these ancestors might have been linguistically (see chapter 6 of this article).

The predecessor of modern South Saami in the Early Iron Age is called the southwest dialect of Proto-Saami by Aikio (2012: 77). It is not the predecessor of South Saami alone, but also of Ume Saami and perhaps Pite Saami. I will call this dialect Southern Proto-Saami, and although this article deals mainly with South Saami vocabulary, I acknowledge that Southern Proto-Saami is also the predecessor of at least Ume Saami. At first, Southern Proto-Saami was a variety that diverged from Common Proto-Saami sometime between 1-500 CE (Aikio 2006: 43; 2012: 77), but gradually it developed into a separate protolanguage and then into Ume and South Saami.

\section{I.2. The datasets}

My linguistic data consists of North-West Germanic (NwG) and Early Proto-Scandinavian (PScand) loanwords in South Saami (SaaS). The loanwords are defined as NwG or PScand by examining regular sound changes in the words (about sound changes and etymologies see e.g. Campbell 1998; K. Häkkinen 1997: 9-74). These loanword strata can be dated, with the help of runic inscriptions, to the Roman Iron Age (1-40o CE) and Migration Period (400-550 CE) (J. Häkkinen 2010b: 55). I will do a Wörter und Sachen 
inventory on the semantic categories of the words in the loanword strata to see from which life domains words were borrowed. I will also examine prominent individual words that might have significance as intercultural markers. I have aimed at including all the words etymologized to NwG and early PScand loanword strata in the data but decided to limit my data to words borrowed into early PScand (which has hypothetically been spoken around 200-550 CE). Limiting the lexical material to NwG and early PScand makes it possible to keep the archaeological material of this small study manageable. (On PScand sound changes and sound changes leading to Late PScand, see e.g. Heikkilä 2014; Koivulehto 2002, 589.)

Many of the Proto-Scandinavian loanwords in South Saami are found in several other Saami languages, some even in all. However, there are more than 30 Proto-Scandinavian loanwords that have been borrowed separately into South Saami. These show phonological and semantic differences compared to the same words in other Saami languages. Some of the words cannot be found in any Saami languages other than South (and often also Ume) Saami. (Aikio 2012: 77-79, 110-111; Piha \& Häkkinen forthcoming). These words suggest that there was a distinct Southern Proto-Saami dialect in the Early Iron Age that borrowed words from Proto-Scandinavian. Because of the disintegration of Southern Proto-Saami dialect and its presence in central Scandinavia by 400 CE (or earlier, as I will suggest in chapter 6), it is necessary to study the dialect and its language and cultural contacts separately from those of other Saami languages. The same applies to the archaeological material: the remains in the southern part of Saepmie (the land of the Saami, the area inhabited by the Saami) should not be interpreted on the basis of research done in the northern areas, as the contexts of the remains in southern Saepmie differ from those in the north (Gjerde 2016: 222). However, comparing the southern and northern material is fruitful and necessary in order to examine how the cultures in the areas differ. There have undoubtedly been many similarities, which can also be seen in the common PScand loanword strata in the Saami languages.

The archaeological material includes those remains in Dalarna, Härjedalen and Jämtland, Sweden ${ }^{2}$ from the Roman Iron Age and Migration Period that can, according to previous research, be connected with an Iron-Age Southern-Proto-Saami-speaking culture. I will take into account remain types, artefact finds and to some extent remain structures dated to the Roman Iron Age and the Migration Period. I will classify the 
archaeological material into archaeological categories and find groups. Only those sites that have been excavated will be included in the data. I have collected the material from archaeological field work reports and published literature.

In chapter 2, I will introduce the theoretical model, after which I will present and analyze the lexical (chapter 3 ) and archaeological (chapter 4) data. I will combine these data in chapter 5 and discuss the benefits and problems of combining archaeological and lexical research. Finally, I will give new perspectives on the South Saami prehistory in chapter 6.

\section{The theoretical model}

Attempts to combine archaeological and linguistic evidence are not a new phenomenon, but most of the major studies thus far have been conducted on Indo-European languages and prehistory (e.g. Anthony 2007; Mallory 1989; Renfrew 1987). Prior research has led to the creation of large syntheses on the origin of modern (language) groups (Saarikivi \& Lavento 2012: 178). However, similar syntheses on the origin of the Uralic languages and peoples have been carried out as well (e.g. Carpelan \& Parpola 2001; J. Häkkinen 2007; Kallio 2006; Parpola 1999; 2012; 2017.), although the nature of linguistic study regarding Finno-Ugric languages is completely different from Indo-European studies. There is written evidence concerning the Indo-European languages dating back thousands of years, whereas the starting point of Finno-Ugric studies is the modern language forms, since no written records older than the Middle Ages are known. ${ }^{3}$ In this article, I will examine the linguistic and cultural contacts between groups over a designated period of time in a restricted geographical area rather than create a synthesis of the origin of a language and its speakers.

Not many detailed theoretical models have been presented for combining archaeological and linguistic material. One such model has been sketched by Janne Saarikivi and Mika Lavento (2012). Their model is applied to an extensive set of data: from the perspective of linguistics, all language features, from phonetics and layers of vocabulary to toponyms and language contacts, are taken into account. An archaeological feature is given for all the language features, e.g. a phonetic feature of an individual speaker would hypothetically correspond to a vessel made by a particular individual, and a layer of vocabulary is cognate with artefacts and artefact types (Saarikivi \& Lavento 2012: 206). The model I present here 
concentrates on a layer of vocabulary that relates to a specific time period, contact network, artefacts and structure remains.

Four main concepts are used within the theoretical model: archaeological find groups, archaeological categories, lexical finds, and semantic (lexical) categories (Figure 1). Archaeological find group is a concept encompassing artefacts and other remains found in archaeological excavations, such as knives, awls or bones of sheep/goat or elk. It subsumes the term artefact type but is broader: it also includes structures such as hearths or house remains. These find groups can be classified in archaeological categories such as tools, animal bones or buildings. Lexical finds are the separate words of a lexicon under examination: words like axe, knife, sheep and $e l k$ are examples of lexical finds. ${ }^{4}$ These words can be classified in semantic categories based on their meaning. Tools would be one semantic category, animals another. When using the theoretical model, the archaeological categories are most often examined in parallel with the semantic categories and the archaeological find groups are contemporaneous with the lexical finds (Figure 1).

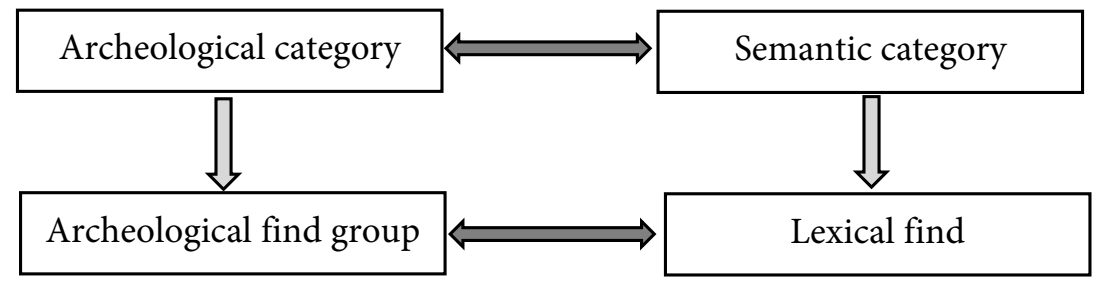

Figure 1: The theoretical model to combine archaeological and lexical material

\section{I Perspectives on categorization in linguistics and archaeology}

Categorization is a way of construing existence and is thus a question of ontology. Within an ontology it is possible to classify phenomena into hierarchical categories different in their degree of generality or detailness. For examples animals can be classified into a very ambiguous category of animals which can, in turn, be devided into the categories of wild animals and domesticated animals. Within the category of wild animals, one could classify categories of e.g. predator animals and prey; domesticated animals might include words for sheep, cow, swine and dog, while the more exact 
category of livestock includes only the first three animals. In different cultures and within different livelihoods different animals might be included in the category of livestock; in some cultures, there might not be division between wild and domestic animals.

Archaeological and lexical finds refer to phenomena within an ontology, and to understand their existence within the ontology, one can classify them in categories. However, categorization is an etic perspective of the researcher and is therefore a tool of research (e.g. Hill \& Evans 1972: 232). But people in the past would also have had a need to categorize things, to understand which things are connected and belong together or which are not part of a certain phenomenon or area of life. Still, the etic categories do not necessarily fully coincide with the emic system of the users of the language and phenomena seen in the archaeological material.

As K. Häkkinen (1999: 163) states regarding semantic categorization and Hill \& Evans (1972: 232, 237, 252-255) on archaeological categorization, classification is always based on the purpose for which the categorization is to be used, and there is thus no universal categorization method. I have constructed the categories according to the aims of this research: to combine the archaeological data of Jämtland and Dalarna, Sweden, and the lexical data of South Saami. Another study carried out using the same general model with different data should construct the categories differently depending on the aims of that research. Nevertheless, even if the categorization is a question of perspective, the words and archaeological objects in the research material were known and used in the emic system of the period under examination. Thus, their existence within the emic (and etic) ontology should not be questioned, even if their meaning should. (See also Hill \& Evans 1972: 261-262.)

\section{Archaeological categorization with consideration to the lexical data}

In archaeology, a common method for bringing order to the data is to create typologies of it. The materials are first grouped by their functions or materials (e.g. tools versus weapons or iron objects versus stone objects) and then classified within each group based on morphological and functional characteristics (e.g. within the group of weapons, artefacts such as swords are classified into a different group from spearheads) and, finally, the artefacts are identified as types according to their morphological characteristics (e.g. different types of swords) (Sørensen 2015: 88-89; for 
further research on typologies in archaeology, see also e.g. Hill \& Evans 1972). A similar classification, or categorization as it will be called here, for the archaeological material can be applied within the theoretical model presented here but adjusted to the needs of combining archaeological and lexical material.

Even if categorization of archaeological finds is a much-used method, it is nonetheless a complicated task. The context of finds should be considered: if an axe is found in a grave, is it only a tool or does it have other meanings, for example more symbolic ones that are related to death or the person buried with it? Works e.g. by Hodder (1982) and Hodder \& Hutson (2003) stress the symbolic and social meanings behind the material culture. Taking this sort of perspective into account, it is not easy to define into which category an archaeological find group should be placed. Olsen (2003; 2010), in turn, emphasizes the significance of the archaeological material itself. He states, "[w]hatever symbolic roles [objects] may play are residues of the primary significance of their own being" (Olsen 2010: 153; see Hodder 1982: 11). Thus, an axe is an axe even if it was found in a ritual or any other context. Here, I will categorize the archaeological data mainly by examiming the finds themselves and not their symbolic meanings to such an extent as e.g. Hodder (1982) deems significant. This is due to the aims of the model as a tool of research for combining archaeological and lexical material: as the denotative - not connotative, or born in the pragmatic context of the speech situation - meanings of words will be examined, it is more practical to examine the archaeological material as it is without its symbolic meanings. However, in the interpretation of the data, I will consider the symbolic, contextual and other possible meanings the objects may have when necessary. It should be noted, after all, that functional and symbolic (as well as other) meanings are not contradictory - an archaeological object may have both or all (Hodder \& Hutson 2003: 175).

Iron axes, iron knives and stone knives are all examples of archaeological find groups. Find groups consist of all the individual finds in the data that can be subsumed under the concepts. They fall within two different archaeological categories: axes and knives. The artefacts in these find groups are often interpreted as tools, and therefore they belong to a more ambiguous category of tools. This interpretation is, however, a strongly etic view of the artefacts, and, as stated above, other interpretations can be made according to e.g. the context of the find. The category of tools can be supported by function. Even if the emic understanding of the objects is 
broader and more complex than the etic, the objects have also had functional properties as tools or symbols for tools. This is, at least, a possible etic interpretation if words referring to axes and knives were known during the period under scrutiny. Thus, there are two layers of categories: the category of tools as the main category and the categories of axes and knives as subcategories of tools.

However, axes and knives can also be regarded as find groups. Artefacts can be divided into find groups according to their type, the material they are made of, the function they have or perhaps the context in which they were found. If there are many knife or axe types in the data and it is necessary to examine them as separate find groups, the knives and axes are seen as subcategories and the different knife and axe types as find groups. If there are not many artefact types or it is not necessary to divide them into separate find groups, they can be understood as a single find group. The boundary between a category and find group thus depends on the perspective and aims of the research.

If there are many lexical finds referring to knives and axes, it is particularly important to examine the knife and axe types as separate find groups: the question of the relation between the different lexical finds and different artefact types should be pondered. Such examination is not always needed as there might be only one word for knife or axe. In such a case, all the different knives could be handled as a general find group of knives. Nevertheless, even if there is only one word referring to knives, one should discuss whether the word refers to knives in general or to a particular knife type.

Osteological material is another archaeological category that is often in need of division into main categories and subcategories. The material can be categorized, for example, into subcategories of human bones, animal bones and undetermined bones, or they could be classified, as I have done in this research, into the main categories of animal bones and human boness. The animal bones are further divided into the categories of wild and domestic animal bones. As mentioned above, these categories can be divided into even more specific categories, such as livestock and pets. The decision on how to categorize archaeological material should be made research-specifically according to the ontological criteria, research questions, data and contexts. 
Semantic categorization of lexical finds with consideration for the archaeological data

As for the semantic categorization of lexical finds, this is done by examining the synchronic, denotative meanings of the word. Even though the semantic-pragmatic perspective has been addressed in recent studies on historical semantics (Durkin 2009: 227; see also K. Häkkinen 1997, 37), the connotative meanings are difficult to determine for words without the speech context. Furthermore, the connotative meanings are connected to the denotative meanings: connotation fits the word into the context it is used in, but it is associated with the denotative meaning (K. Häkkinen 1997: 39). Then again, many words are polysemic and have two denotative meanings, some even three. All of the denotative meanings of the words should be considered, but usually one primary denotative meaning can be detected by, for example, examining the etymology of the word or the concreteness of the meaning.

One challenge is the study of changes in the semantics of words, as it is often difficult to carry out a systematic analysis of these (Durkin 2009; 222). The synchronic meaning of a word is not always the same as the diachronic: a word that has, for instance, a religious meaning today, might not have had one before and vice versa. The semantics of words change when the world changes, and thus meanings that were relevant in history might not be so anymore. Such changes are strongly connected to extralinguistic factors (Durkin 2009: 260-265). Nevertheless, there is a connection between the old and new meaning (K. Häkkinen 1997: 52), and therefore it is often possible to draw conclusions on the nature of the semantic change when uncovering the etymologies of words. Sometimes it is impossible to obtain information on the semantic changes if the old changes cannot be seen in the word in any way. In such cases, we can only make assumptions on the words' possible, extinct meanings. (On semantic change, see e.g. Campbell 1998: 256-273; Durkin 2009: 222-265; K. Häkkinen 1997: 33-56.)

However, combination of archaeological and lexical material might reveal aspects that can help in interpreting the archaeological material and semantic changes of words. If some artefacts are repeatedly found in a religious context but the word referring to the artefact does not have a religious connotation, it might be possible to interpret the word as having had a religious meaning at the time when the religious phenomena occurred - it could thus be classified in the category of religion. As these are more or 
less speculations, I have decided to categorize the lexical data according to their synchronic meaning but to address the possibility of other categories in my interpretation of the datasets.

In general, similar methods of categorization to those used for archaeological data can be used in categorizing lexical finds in semantic categories. There are semantic categories of different levels: names of animal species form the main semantic category of animals, which contains subcategories such as wild animals and domestic animals. These could be divided into another set of subcategories, e.g. domestic animals into pets and livestock. Again, the number of hierarchical layers used to divide the categories depends on the aims and perspective of the research.

Once the categorization is complete, it is possible to combine the two datasets at the level of categories and lexical finds and archaeological find groups. However, while the categories are used to understand the areas of life to which the lexical and archaeological finds might belong, as discussed above, categorization is a complex and even ambiguous task. It is the actual data - lexical and archaeological finds - that are central to the analysis.

It should be noted that, when utilizing the theoretical model, there must be previous knowledge or an existing hypothesis about the language(s) spoken within the research area or archaeological culture. When applied to a suitable set of material, the model can, at its best, verify or refute the hypothesis of an archaeological culture, remain type or other entity having belonged to a people who spoke a certain language. If enough reliable counterparts are found, the hypothesis can be verified; if not, it will be refuted.

\subsection{Hypothetical example of how to use the model}

The material for this hypothetical example (archaeological find groups of knives, axes, bones of sheep/goat and elk; lexical finds knife, awl, sheep, elk) is presented in Table 1. The lexical finds are loanwords in language A from language $\mathrm{B}$, and the archaeological material is from the area where language $A$ is known to have been spoken. The aim is to examine the language and cultural contacts between languages $\mathrm{A}$ and $\mathrm{B}$ and their speakers.

The archaeological find groups of iron axes, stone knives and iron knives form the main archaeological category of tools. As there are knives made from two materials (stone and iron), it is necessary to create a subcategory of knives within the main category of tools. The subcategory is 
made up of two archaeological find groups: stone knives and iron knives. In the example, iron tools are a novelty among the culture of language $\mathrm{A}$ speakers, and the distribution of iron knives suggests that they come from the nuclear areas of the culture of language B speakers. Stone knives are already known from earlier periods.

There is also a main semantic category of tools on the lexical side of the example. It is made up of two lexical finds: knife and $a w l$. No necessary subcategories have been detected for these lexical finds. In modern language $\mathrm{A}, k n i f e$ is a general word referring to any kind of knife. This fact is of interest because there are two different archaeological find groups to which the lexical find might refer.

Combining the two datasets reveals that a category of tools is present in both the archaeological and lexical material. Within this category, there are archaeological counterparts for the lexical find knife but not for awl. There is an archaeological find group of iron axes without a corresponding lexical find. If we looked at only the archaeological material, we would have proof of usage of tools such as knives and axes, but we could say nothing of awls. If we looked at only lexical material, we would have proof of usage of awls and knives but would know nothing of axes. The archaeological and lexical material thus complete one another: we can say that axes, awls and knives were all known to the people of the culture in question.

The archaeological material suggests that iron axes along with other iron objects came from the culture of speakers of language $B$, but it is curious that the word was not borrowed from language B. The etymology of the word axe in language A should be examined in order to draw information on where the word comes from and, perhaps, to find out why it was not borrowed from the same source as that from which the concept was adopted. As for the word $a w l$, it is a loanword from language B. It is probable that the concept it refers to is a novelty that came from the speakers of language B. For one reason or another, the data contain no archaeological material on awls.

The question of knives in the data is more complicated. As mentioned above, there are knives made of two materials in the archaeological data, but only one word referring to knives. As knife is a loan from language B, it is possible that the word was borrowed along with the knives made of a material previously unknown to speakers of language A, i.e. iron. The people using the word and the knives had, perhaps, a different word for stone knives, which disappeared once the stone knives fell out of use and the 
word was no longer needed. The meaning of knife might have expanded only during modern times to include the stone knives found in the archaeological excavations.

As for the bones, the archaeological find groups of sheep/goat bones form an archaeological subcategory of domestic animal bones. The bones of elk form a subcategory of wild animal bones, and together these subcategories form the main archaeological category of animal bones. The find groups of sheep/goat and elk correlate with the lexical finds sheep and elk, which form the main semantic category of animals. There are two semantic subcategories within the main category: domestic animals for sheep and wild animals for elk.

It is difficult to say why a new word for elk was borrowed from language $\mathrm{B}$. The area where language $\mathrm{A}$ was spoken during the period under scrutiny did have elks even before contacts with language $B$. This can be seen in osteoarchaeological material of elk from previous periods. Perhaps the new word had something to do with trade concerning elk products, such as the hide or antlers. The lexical find of sheep can be of assistance to archaeologists: because there is a word for sheep in the example language borrowed from language $\mathrm{B}$, it is more likely (but not certain) that the bones in the archaeological material come from sheep and not goat, as there is no word for goat that could be used in reference to the archaeological material in the research. The sheep bones and word for sheep might indicate that sheep herding has come to language A speakers from language $B$ speakers.

In this hypothetical material, knives have been found in graves. In table 1, the knives are classified as tools, but clearly, considering their find context in graves, they might have ritual or religious meanings as well. However, there are no words in the data suggesting this interpretation; instead, there is a general word without any connotations for a tool called knife, and it can be connected to archaeological finds of knives, which also are tools. This much is obvious from both datasets. The archaeological find context suggests that there is more to the knives than merely a function as sharp tools meant for cutting or whittling, and therefore the question of whether the word knife also had a religious connotation during the time of usage of the graves and knives should also be discussed. Thus, the archaeological material may reveal past connotations or usage contexts of the words. The knives may also be indicators of other phenomena, such as the identity of the buried. 
The same applies to other archaeological objects. For example, even if animal bones are found in garbage pits at dwelling sites, they may be indicators of more than just animals and disposal: they may indicate food habits and livelihoods, or even rituals. As for the awls, the lexical material indicates that an awl has been an object known to the language speakers, perhaps even one used by them, but the contexts in which it was used are not known as there are no archaeological finds of awls in the data. Because the knives and axes have been found in graves, the question arises as to whether awls have also been placed as grave goods.

\begin{tabular}{|c|c|c|c|c|c|}
\hline \multicolumn{2}{|c|}{$\begin{array}{l}\text { Archaeological } \\
\text { category }\end{array}$} & \multirow[t]{2}{*}{$\begin{array}{l}\text { Archaeological } \\
\text { find group }\end{array}$} & \multirow[t]{2}{*}{ Lexical find } & \multicolumn{2}{|l|}{$\begin{array}{l}\text { Semantic } \\
\text { category }\end{array}$} \\
\hline Main & Sub & & & Sub & Main \\
\hline \multirow[t]{4}{*}{ Tools } & & iron axes & & & \multirow[t]{4}{*}{ Tools } \\
\hline & \multirow[t]{2}{*}{ knives } & stone knife & \multirow[t]{2}{*}{ knife } & & \\
\hline & & iron knife & & & \\
\hline & & & $a w l$ & & \\
\hline \multirow[t]{2}{*}{$\begin{array}{l}\text { Bones of } \\
\text { animals }\end{array}$} & $\begin{array}{l}\text { domestic } \\
\text { animals }\end{array}$ & $\begin{array}{l}\text { bones of } \\
\text { sheep/goat }\end{array}$ & sheep & $\begin{array}{l}\text { domestic } \\
\text { animals }\end{array}$ & \multirow[t]{2}{*}{ Animals } \\
\hline & $\begin{array}{l}\text { wild } \\
\text { animals }\end{array}$ & bones of elk & elk & $\begin{array}{l}\text { wild } \\
\text { animals }\end{array}$ & \\
\hline
\end{tabular}

Table 1: Hypothetical examples for using the theoretical model

\section{The lexical material}

The lexical material of my research consists of SaaS words that are etymologized as being of PScand origin. I have included only those words that have been given a proper etymology with reconstructed PScand forms. As a general rule, I have not etymologized any new words, choosing instead to collect all my material from literature ${ }^{6}$. However, some of the PScand forms have been reconstructed for other purposes (such as for etymologizing Finnish words). In cases where I have judged the sound changes between the reconstructed PScand form and the SaaS word to be regular, I have included the etymology in my material. 


\section{I. Semantic categories}

The material consists of 163 SaaS words borrowed from NwG and PScand language strata. Approximately 30 of the words in the material seem to have been separately borrowed into Southern Proto-Saami (Piha \& Häkkinen forthcoming). This means that they are not found in the other Saami languages, or that they require a different PS form from those in the more northern languages.

\begin{tabular}{|c|c|}
\hline Semantic category & $\begin{array}{l}\text { Number } \\
\text { of words }\end{array}$ \\
\hline Action processes (verbs) & 8 \\
\hline Adjectives & 19 \\
\hline Agriculture and domestic animal husbandry & 12 \\
\hline Animal handling & 1 \\
\hline Body parts & 9 \\
\hline Buildings and constructions & 6 \\
\hline Clothing & 4 \\
\hline Conditions and changes & 2 \\
\hline Flora & 13 \\
\hline Food and cookery & 11 \\
\hline Humans and humans as members of society & 10 \\
\hline Hunting and fishing & 2 \\
\hline Natural phenomena & 4 \\
\hline Reindeer and reindeer husbandry & 9 \\
\hline Relations in space and time & 4 \\
\hline Religion and beliefs & 5 \\
\hline Terrain and landscapes & 8 \\
\hline Water and watersystems & 6 \\
\hline Wild animals & 11 \\
\hline Work-related words & 10 \\
\hline Vehicles and travelling & 6 \\
\hline Other words & 3 \\
\hline Total & 163 \\
\hline
\end{tabular}

Table 2: Semantic main categories of the NwG and PScand loanword strata in SaaS 
The semantic categories and the numbers of words in each are presented in Table 2 on the previous page. The words, etymologies and semantic developments are presented in detail in Appendix 1. There are 22 primary semantic main categories in the research material. In addition to this, there are two semantic main categories that occur only secondarily: fire ( 2 words) and trade ( 1 word). Some of the main categories are divided into subcategories if such a division is necessary.

The largest category in the material is that of adjectives with 19 words. It is followed by flora ( 13 words/ 1 with secondary meaning), agriculture and animal husbandry (12/6), food and cookery (11/1), wild animals (11/o), work-related words $(10 / 3)$, humans and humans as members of society (10/2), body parts (9/1) and reindeer and reindeer husbandry ${ }^{7}(9 / 2)$. The rest of the categories contain eight or fewer words. Adjectives, action processes and conditions and changes are not semantic categories in the same sense as the other categories that generally refer to concrete objects around one semantic domain. I have classified words into these categories if another suitable, more precise category could not be found. It should be noted that the categorization of words has been made according to the modern meanings, not to the reconstructed meanings of the Southern Proto-Saami words at the time of borrowing.

The categories are partly based on K. Häkkinen's articles (1999, 2001) concerning lexical categories of prehistoric Finno-Ugric culture, however, as $\mathrm{K}$. Häkkinen notes, it is difficult to classify words into semantic categories. As stated above, it is the etic perspective of the researcher's aims that define the categorization. In my data, for example, I have detected a vast vocabulary of domestic animal names. Because the Saami speakers in the hunting ground areas of Jämtland and Dalarna have not traditionally practiced domestic animal husbandry, it is in my interest to examine words referring to domestic animals. I have decided to classify the words into the category of domestic animals (and agriculture), not to place them e.g. into an ambiguous category of animals. The aims and nature of my research are different from those of K. Häkkinen's, which is why her work is more of a model and source of inspiration for me. 


\subsection{Language and cultural contacts in the light of the loanwords}

In this chapter, I will summarize the analysis of the lexical finds and the semantic categories made up of the lexical finds. The material is provided in detail in Appendix 1.

\section{Nature and animals}

The semantic categories that refer to nature and natural phenomena are flora, natural phenomena, terrain and landscape, water and water systems and wild animals. Altogether, the number of words in the categories is 42 , or more than one quarter of all the words.

The data contain no words referring to wild terrestrial mammals. The wild animal vocabulary includes names for marine animals, birds and insects. Bird names include the predatory birds aarhtse 'eagle' and haepkie 'falcon', but also svaaloe 'swallow'. The marine animal vocabulary is notable, and all of the marine animal names are found in all or almost all the Saami languages. It seems that PScand speakers have been involved in (Southern) Proto-Saami speakers' exploitation of marine resources. In addition, two words referring to fishing have been borrowed from PScand: nuehtie 'seine net' and staavra 'pole, fishing rod'. The latter word's reference to fishing might be secondary: the $\mathrm{ON}$ meaning is 'pole', and in other Saami languages the cognate words have the meaning of 'staff, long stick'.

The vocabulary for flora is more scattered than that of wild animals. However, all of the words for flora refer to plants that grow in the boreal forest of Scandinavia. Seven of the words refer to forests or trees, while only one refers to smaller plants. In addition, the word for grass in SaaS was borrowed from PScand.

The rest of the words with a connection to nature describe the environment that was significant to the Southern Proto-Saami speakers: they refer to places where the speakers dwelled or where their contacts with the PScand speakers occurred. Many of the terrain and landscape words refer to mountaneous terrain. In the semantic category of water and water systems, there is further evidence for the importance of the sea in the contacts between the Southern Proto-Saami and Proto-Scandinavian speakers: the word aepie 'open sea, high seas' is borrowed. Additionally, the word fierve 'low tide' - a significant word for all seafarers - is borrowed from PScand. 


\section{Sources of livelihood}

The sea as an important source of livelihood was mentioned in the section on nature and animals. According to the loanword data, Proto-Scandinavian speakers were involved in other means of livelihood of the Southern Proto-Saami speakers as well: agriculture and animal husbandry as well as reindeer and reindeer pastoralism. Clothing or food and cookery are not sources of livelihood, but they are direct results of a livelihood.

The semantic category of agriculture and animal husbandry is one of the largest in the lexical material, and the contacts around these phenomena must have been intensive. The vocabulary referring to animal husbandry contains names of domestic animals: täjhkoe '(female) dog', saavhtse 'sheep', laampe 'lamb', gaajhtse 'goat', vïerhtse 'ram', vuaksa 'ox', govse 'cow' and gaelpie 'calf of a cow'. Furthermore, clothing vocabulary referring to fabric and commodities made of wool and linen (lijnie 'shawl', vaanhtse 'mitten', vaarese 'homespun fabric', vaarjoeh 'clothes') are borrowed from PScand and could be categorized secondarily under agriculture and domestic animal husbandry. ${ }^{8}$ It should be deduced that the Southern ProtoSaami speakers of the Roman Iron Age and the Migration Period were not only familiar with animal husbandry but also practiced it themselves. If they had only known about it, the domestic animal vocabulary adopted from PScand would not be so extensive. As I will later discuss, the archaeological material also supports this hypothesis.

The vocabulary referring to cultivation is much scarcer than that of animal husbandry. There is only one word with a primary meaning of cultivation: aegnieh 'chaff, husk'. Nonetheless, in the semantic category of food and cookery, there are four words that very well might be connected to cultivation: two words for bread, one for dough and one for porridge. It is possible to make porridge and even bread out of seeds and grains from wild plants, but as the words are borrowed from a language whose speakers practiced agriculture, it is probable that these words referred to food made from cultivated plants. However, it should be kept in mind that the Proto-Scandinavian speakers might have traded flour and grain with the Southern Proto-Saami speakers. Therefore, the Southern Proto-Saami speakers did not necessarily practice cultivation themselves.

Additionally, the word aernie 'hearth (in a Saami hut)', classified in the category of buildings and constructions, might have been connected to agriculture and cookery. In one Swedish dialect, the word ären, arne refers 
to the bottom of baking oven (SSA 1 s.v. arina). The meaning of the PScand word ${ }^{*}$ aRina has been reconstructed as flagstone. Heated flagstones were used to bake flatbread during the Iron Age in Scandinavia. It seems that the word aernie might have referred to this sort of baking oven, which would have been a novelty among the Southern Proto-Saami speakers, adopted from Proto-Scandinavian speakers. The meaning expanded only later to refer to hearths in general.

The words referring to humans who practice agriculture or animal husbandry are more complicated than the names of animals, food or other agricultural terms. One example is the term laedtie 'farmer; person with a fixed residence'. The word has no connotation of language or ethnic affiliation, which means that laedtie could have referred to either Proto-Scandinavian or Southern Proto-Saami speakers. Nevertheless, small-scale animal husbandry could have been practiced as some sort of side livelihood in addition to the more traditional way of life: the people took their sheep or goats with them when they moved from the winterlands to their summer camps and back. Slash and burn fields would also have allowed the traditional seasonal migration for a population with hunting and gathering as its main livelihood. In Pite Saami there is a loanword from PScand for slash and burn fields: assko (Qvigstad 1893: 94; Koivulehto 2003: 289290; LÄGLOS 1 s.v. $a h k u$ ). Another word that refers to a farming person is svaajnes 'farm worker'. The meaning in $\mathrm{ON}$ is 'boy, lad; male servant'. It might have referred to a Southern Proto-Saami speaking person who started working, for example, at a farm of Proto-Scandinavian origin. There is also a name for non-Saami people in the PScand loanword strata: daatje 'Norwegian, Swede'. This word does not, however, make reference to the livelihood of the non-Saami person. Words referring to a house (ståapoe) and storage building (buvrie) have also been borrowed from PScand, and it is likely that they were borrowed in connection with agriculture and domestic animal husbandry.

In addition to agriculture and animal husbandry, it seems that ProtoScandinavian speakers would have influenced the Southern Proto-Saami speakers' livelihood of reindeer pastoralism during the Iron Age. However, $\mathrm{ON}$ and the modern Scandinavian languages show that the semantics of the words have changed quite drastically from their original meanings to the Saami meanings. In fact, none of the Scandinavian source words refer to reindeer. They have more general meanings as in ON hauss 'skull' ( $<$ PScand ${ }^{\star} h a u s a>$ SaaS aevsie 'the part of a reindeer's skull that comes 
away with the antlers when they are cut off; the part of the skull that is between and around the antlers (of a living reindeer)'), or a meaning that describes the Scandinavian culture as in ON reið 'riding; cart'; S rida 'riding, cart' (< PScand ${ }^{*}$ rāi đō $>$ SaaS raajroe 'reindeer caravan'), or ON kru 'a small corral for cattle' ( $<$ PScand ${ }^{\star} k r e u(h)>$ SaaS krievvie 'reindeer herd (that is herded by a reindeer shepherd)').

In the light of the semantic development of the reindeer vocabulary borrowed from PScand, it seems that Scandinavians did not necessarily have an influence on the livelihood of reindeer pastoralism. At the time of borrowing, the words had more general meanings that did not refer to reindeer in the Southern Proto-Saami. Reindeer pastoralism should be seen as an internal development in the Saami speaking culture that has, perhaps, been influenced by an unsuccessful attempt at animal husbandry and cultivation. The transition to reindeer pastoralism would have taken place during the Viking Age at the earliest (Storli 1993: 3, 20). (For a short introduction to the genesis of reindeer pastoralism, see also Hansen \& Olsen 2006: 198-209.) As my anonymous referee kindly noted, some of the loanwords might also be explained by Saami speakers having kept a few tame reindeer already during the Early Iron Age to transport trade products by reindeer caravan to Scandinavian speaking groups. This hypothesis requires a semantic change in the Saami words almost immediately after borrowing.

\section{Work and travelling}

The meanings of work-related words do not differ much from those in the Scandinavian languages. Many of the words referring to work, tools and materials are connected to iron. First, many of the tools with names borrowed from PScand can be associated with iron, including the words for axe, knife, edge of a knife and perhaps also sheath. Artefacts with similar functions to axes and knives were certainly known among Proto-Saami speakers before Southern Proto-Saami diverged into its own dialect, but they might have been made of other materials than iron or have otherwise differed from the ones I connect to the PScand words. The old tool types might have had different names that disappeared from the modern language when they fell out of use. At any rate, new names for tools with at least a partly familiar usage context were borrowed from PScand. This indicates new material, new processing methods or new types of familiar 
tools that were referred to using PScand word among the Southern ProtoSaami speakers. The word for iron (SaaS ruevtie) is a borrowing from ProtoGermanic (Koivulehto 1976: 247) so the Saami speakers were familiar with the material hundreds of years before borrowing the PScand words (see e.g. Piha 2016: 73). Therefore, the appearance of a new material is an unlikely event. Second, the word aassjoe 'hearth in a smithy' refers to iron processing. The word is classified primarily as a fireplace within the category of buildings and constructions, but it could also be categorized as a work-related word. ${ }^{9}$

Another interesting group of words is also those referring to materials: tin, silver and blubber oil. Even though words referring to the trading act itself are scarce in the research data, these commodities as well as the iron tools and previously mentioned marine animals and predatory birds could be interpreted as merchandise, perhaps through exchange trade or gift exchange between the chieftains of the tribes. I have not categorized them as trading words because no connotations related to trade can be seen in the words.

Two of the words in the category of vehicles and travelling refer to boats: aajroe 'oar' and dälja 'sitting board in a boat'. Seafaring vocabulary had already been borrowed from the earlier, Germanic loanword strata into Proto-Saami (Piha 2016: 43 and the references there) so the Proto-Saami speakers very likely learned new techniques for passing through the waters from the Germanic and Scandinavian speakers. Larsson (2007: 123-124) states that according to written sources, Saami boat-building was famous among the neighbouring people, and there was boat trading between the Saami and the Scandinavians during the Middle Ages and probably already during the Late Iron Age. The PScand loanwords in SaaS indicate that the roots of the boat trade already date back to the Early Iron Age.

\section{Religion}

The semantic category of religion and beliefs consists of five words and it is not possible to say much about PScand speakers' effect on Early Iron Age religion of the Southern Proto-Saami speakers from those words. The ON cognates of the words saajve 'a mythical creature living inside mountains' and aajmoe 'the other world' have no visible religious meaning. The last three words in the category (raavke 'apparition', aejlege 'holiday, Sunday', faastoe 'fast') have not undergone any drastic semantic changes. 
The PScand loanword faastoe 'lent; fast' had nothing to do with Christian Lent at the time of borrowing; it most likely referred to (non-religious) fasting in general. I have placed the word in the semantic category of religion because, as stated earlier, I have made the the categorization according to the modern meanings of the words. In modern South Saami, the word refers to religious lent (Bergsland \& Mattson Magga 2007 [1993] s.v. faastoe).

\section{Human, human body and humans as members of society}

There are some names for humans in different phases of their lives and their status in the society borrowed from PScand. Of great interest from the perspective of contacts are the words alluding to relatives: provrese 'bride' and maake 'man married to an aunt'. Both words strongly indicate marriages between a Southern Proto-Saami-speaking woman and ProtoScandinavian-speaking man. In addition to these, the word aerpie 'legacy' is borrowed from PScand and might also be connected to the institution of marriage and the children born within intercultural marriages. The borrowed word baernie 'boy, son' is significant in this light as well. In ON, however, the word referred to a child in general.

The semantic category of body parts could, of course, refer also to animals. It is interesting that three words for throat were borrowed from PScand, two of them exact synonyms of each other and one that means 'palate'. It is difficult to guess the need for so many words. Perhaps one of the synonyms for throat and larynx was meant for the human throat, while the other was used for animals. However, there is no evidence of such a separation in the later Scandinavian or South Saami languages.

\section{Missing and other categories}

One of the most notable semantic categories missing from the data is that of trade. I have classified the word laajkoe 'debt' secondarily into the category of trade, but it does not reveal much about the trading customs between the Proto-Scandinavian and Southern Proto-Saami speakers. There is also the adjective dovres 'expensive', which could be connected to trade. However, if the trading was mostly exchange-based, there might not have been much need for vocabulary referring to the value of commodities, although perhaps silpe 'silver' might count as a currency in trade. Trading vocabulary is also 
scarce in the PG loanword strata of the Saami languages (Piha 2016: 69). However, many of the other PScand loanwords in SaaS might provide insight into what was traded or exchanged, as discussed above.

The other semantic categories in the material are action processes, adjectives, conditions and changes, relations in space and time and other words. Words referring to time (week and month) provide information about the periodization and seasons of the year.

\section{The archaeological material}

In Swedish archaeology, the inland areas of Dalarna and Norrland in Sweden are known as the hunting ground areas (Sw fängstmarker). Sedentary residency is scarce or nonexistent in these areas and the majority of the archaeological remains point to hunting and gathering as the main source of livelihood. As the Southern Proto-Saami speakers have dwelled in the hunting ground areas from a very early date in the Iron Age, it is certain that there are traces of them there, and the material used for this research has been selected with that in mind.

The Saami archaeological material from the Early Iron Age in Dalarna and particularly southern Jämtland is rather scarce. The most intensive period for excavations in the hunting ground areas of Dalarna, Härjedalen and Jämtland was from the 1960 s to the 1980s, partly also in the 1990 s. (For a short introduction to the research history of the hunting grounds, and especially the graves, see Gustafsson 1995: 7-11.) Since the turn of the millennium, only minor excavations have been conducted. However, the old material stored in the archives has also been studied and discussed in recent years by Fossum (2006), Gjerde (2016), Hansen \& Olsen (2006), Olofsson (2010), Stedingk \& Baudou 2006, Wehlin (2016) and Zachrisson (2009, 2014), among others.

The three remain categories included in my research are the so-called hunting ground graves (Table 3), iron manufacturing sites (Table 4) and dwelling places (Table 5). I have limited the archaeological material to those sites that have been excavated totally or partially and have been dated to the Roman Iron Age or Migration Period. The other remains from those periods consist of hunting pits and Scandinavian sedentary sites around Lake Storsjön. These will be only briefly introduced. All of the reference literature, archaeological field work reports and osteological reports used as material for my research are listed in Appendix 3. 


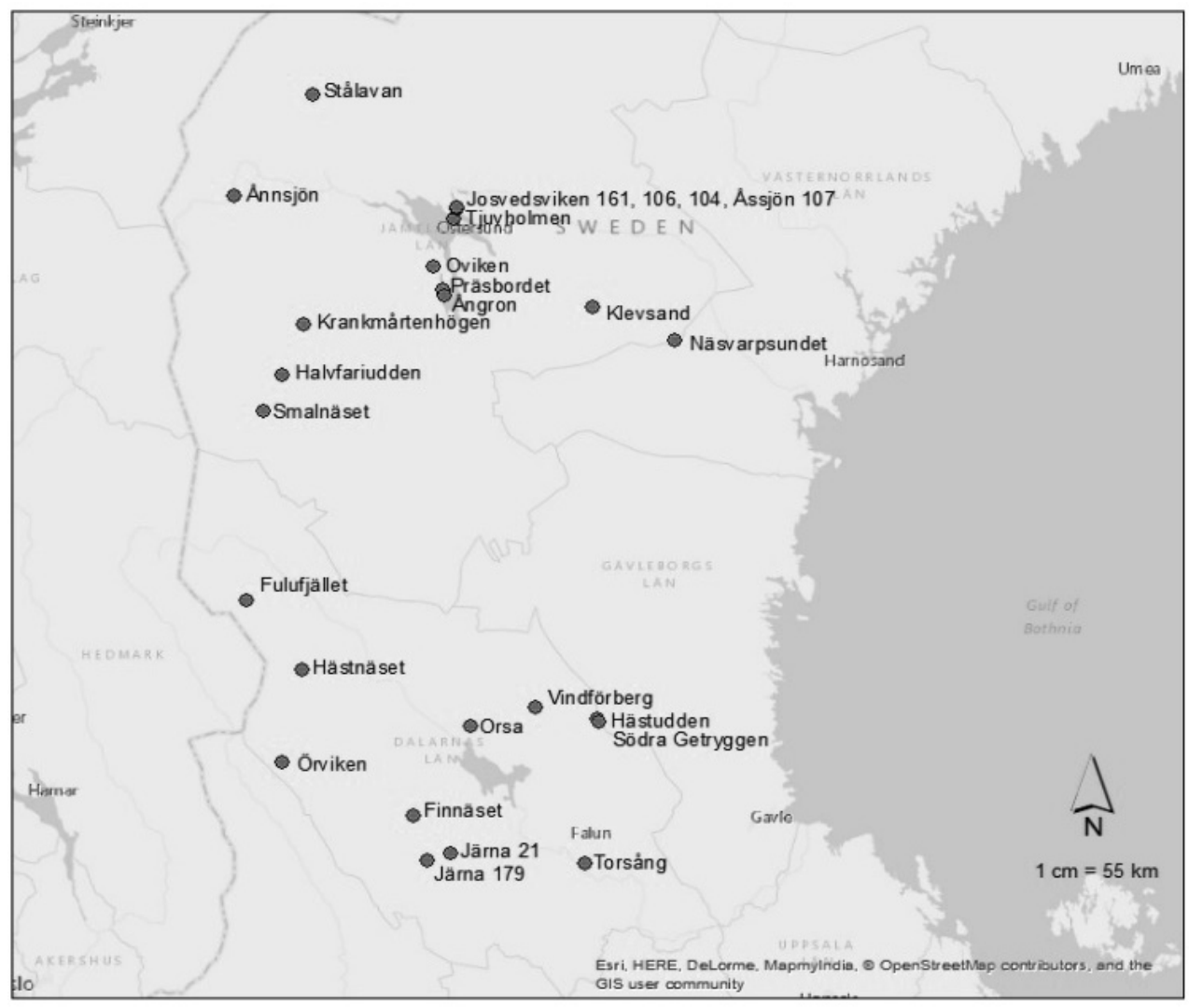

Figure 2: The map of the archaeological remains used as material

\section{I. Remains in the hunting grounds}

\section{Hunting ground graves}

The graves are the best known archaeological remains from the hunting grounds of Jämtland, Härjedalen and Dalarna. The most valuable information the graves provide for this research are the artefacts and osteological material. Therefore, I will mostly concentrate on these. The number of graves included in my research material is 137 (see Table 3).

The hunting ground graves (Sw. fangstmarksgravar), also called lake graves (Sw. insjögravar) or mountain graves (Sw. fjällgravar), are the largest and best-researched remain category in my research material. In Jämtland 
and Härjedalen, 64 hunting ground grave sites are known. The sites hold 230 graves in total. (Sundström 1997: 22.) The number of grave sites in Dalarna is not clear, but at least 12 cemeteries are known, as well as several smaller groups of graves (Wehlin 2016: 221 table, 233-224). Hunting ground graves can also be found in Gästrikland, Medelpad and Ångermanland in Sweden (Fossum 2006: 90), but the heartland of the burial custom lies in Härjedalen, Jämtland and Dalarna. The total number of hunting graves is approximately 600 (Olofsson 2010: 99).

Hunting ground graves were in use for 1500 years, from $300 \mathrm{BCE}$ to around 1200 CE (e.g. Fossum 2006: 90; Hansen \& Olsen 2006: 102; Zachrisson 2009: 137). The datings are often conducted using the radiocarbon method, but artefact-based dating is also common, particularly in the richer graves in Dalarna. The structures, grave goods and numbers of graves in cemeteries have varied over time, but they can, nevertheless, be related to each other in many ways.

The graves are located in forest and fjell areas, a long distance from sedentary settlements. Most of them are found near lake shores or other water systems. (Sundström 1989a: 155.) Additionally, an integrative factor is the placement of the graves and cemeteries at old dwelling sites of a Stone Age character. There may be thousands of years between the use of the dwelling site and the graves, but the meaning of burying the dead at old dwelling places is vastly debated among researchers (see e.g. Gustafsson 1995: 13-14; Fossum 2006: 141).

The graves are constructed as stone settings. They are often round or triangular, but square and irregularly shaped stone settings are also known. Stone chains bordering the graves are common throughout the timespan of the grave custom. The filling soil is most often made up of sand and small stones. Artefacts and other finds from the Stone Age layer can be detected in the filling. It is also quite usual to find flat boulders on or under which the cremated bones of the dead have been replaced. Grave goods vary from site to site and grave to grave, but animal bones, clothing assessories, tools and weapons are common. Rich grave goods, both in quality and quantity, are more common in Dalarna than in Jämtland and Härjedalen. 


\begin{tabular}{|c|c|c|c|}
\hline Grave site & $\begin{array}{r}\text { The number } \\
\text { of graves }\end{array}$ & $\begin{array}{r}\text { Excavated } \\
\text { graves }\end{array}$ & Dating \\
\hline $\begin{array}{l}\text { Krankmårtenhögen, } \\
\text { Härjedalen }\end{array}$ & 30 & 30 & 350 BCE-200 CE \\
\hline Smalnäset, Härjedalen & 34 & 34 & $500 / 100 \mathrm{BCE}-200 \mathrm{CE}$ \\
\hline Örviken, Dalarna & 4 & 4 & $\mathrm{O}-200 \mathrm{CE}$ \\
\hline Fulufället, Dalarna & 4 & 1 & $0-550 \mathrm{CE}$ \\
\hline Finnäset, Dalarna & 16 & 1 & $200(-400) \mathrm{CE}$ \\
\hline Vindförbergs udde, Dalarna & 43 & 43 & $100-550 \mathrm{CE}$ \\
\hline Klevsand, Jämtland & 8 & 1 & $200-500 \mathrm{CE}$ \\
\hline Näsvarpsundet, Jämtland & 4 & 1 & $280+/-125 \mathrm{CE}$ \\
\hline Tjuvholmen, Jämtland & 10 & 1 & $273-571 \mathrm{CE}$ \\
\hline Örviken, Dalarna & 1 & 1 & $400-550 \mathrm{CE}$ \\
\hline Södra Getryggen, Dalarna & 30 & 5 & $400-550 \mathrm{CE}$ \\
\hline Hästudden, Dalarna & 1 & 1 & $400-550 \mathrm{CE}$ \\
\hline Josvedsviken, Jämtland & 1 & 1 & $441-665 \mathrm{CE}$ \\
\hline Hästnäset, Dalarna & 25 & 5 & $500 \mathrm{CE}$ \\
\hline Halvfariudden, Härjedalen & 8 & 8 & $515+/-70 \mathrm{CE}$ \\
\hline Total number of graves & 239 & 137 & \\
\hline
\end{tabular}

Table 3: Cemetery and grave material of the research

\section{The phases of hunting ground graves}

The hunting ground graves in Jämtland and Härjedalen can be divided into three phases (Sundström 1989a: 163). The oldest hunting ground graves are dated to $300 \mathrm{BCE}-200 \mathrm{CE}$. These are found in large cemeteries of about 30 graves in Krankmårtenhögen in the parish of Storsjön and Smalnäset in the parish of Tännas. The stone settings are large, low and triangular or round in form. There are stone chains bordering the graves and the triangular graves have had erect cornerstones. The human bones are cremated and covered with a flat stone. Sometimes the human bones are found in small caskets that have been sealed with resin. Grave goods in the form of artefacts are not common during the first phase. Instead, bones of wild fauna inside the graves and antlers of elk and reindeer on top of them are abundant. (Ambrosiani et al. 1984; Sundström 1989a: 163-164; Zachrisson 
2009: 138-139.) This has been interpreted as a continuation from the Stone and Bronze Age culture of Norrland (e.g. Stedingk \& Baudou 2006: 186). A certain portion of the animal bones found in the graves might come from the Stone Age layers under the graves, and it is not easy to determine whether they are, in fact, connected to the graves. The antlers on the graves are either contemporaneous with the graves or younger (Olofsson 2010: 100; Welinder 2008: 36, 60).

The next phase begins around the beginning of the Late Roman Iron Age (200 CE) and continues until the end of Migration Period (550 CE). The grave locations are now spread out over a broader area than the cemeteries of the first phase. During this phase, the cemeteries are not as big as in the first: each contains 4-10 stone settings. There are also individual stone setting graves. The graves are round in shape or, exceptionally, square. They are still rather large and bordered with stone chains. The cremated human bones are now scattered in the fire layer. (Sundström 1989a: 164.) The second-phase grave sites in my research material are Halvfariudden, Josvedsviken, Klevsand, Näsvarpsundet and Tjuvholm (see Table 3).

The artefacts are more abundant than during the first period, although not if compared to the amount of grave goods from the same period found in Dalarna. Iron knives, glass, bronze and bone artefacts have been found, as well as iron spearheads and a piece of a shield boss. In addition, bones of domestic animals appear in the graves along with those of wild fauna.

The third phase begins at the beginning of the Merovingian Period and continues all the way to the 1200 s. The graves are located in small groups or individually and are no longer necessarily confined to the lake shores and water systems. They still consist of stone settings but are smaller in size and not as regular in form as before. They are not marked in any way and are therefore not visible on the ground. The cremated bones and other finds are scattered within the grave construction. The grave goods are richer than during the first two phases. (Sundström 1989a: 164-165.) Graves from the third phase will not be included in my research.

Although Hansen and Olsen $(2006,103)$ note that the hunting ground graves cannot be regarded as Saami until the beginning of the Viking Age, I regard the graves of the second phase as being connected to Southern Proto-Saami speakers. The Saami ethnicity as we know it from historical times may have arisen during the Viking Age, but the language was there before that (see chapter 6). 
In Dalarna, the division into phases differ slightly from that in Jämtland. The graves can be divided into two phases according to the number of graves in the cemeteries. The time of the large cemeteries with more than 15 graves extends from the beginning of the Common Era until the end of Migration Period (Wehlin 2016: 236). The cemetery of Vinförbergs udde in Ore is the best known and largest of the hunting ground cemeteries in Dalarna (Wehlin 2016: 221). The second phase is characterized by smaller cemeteries with 5-12 graves. It should be noted that small cemeteries and lone graves are known also during the first phase. (Wehlin 2016: 236-237.)

According to Wehlin (2016: 237) the form of the graves does not differ from the first phase to the second, though the nature of grave goods changes, with domestic animals and iron artefacts becoming more common. I have included only the following graves from the first phase in my research: Finnäset, Fulufället, Hästnäset, Hästudden, Södra Getryggen, Vindförberg and Örviken (see Table 3). ${ }^{10}$

\section{Language and ethnic affiliations of the graves}

There is no consensus among archaeologists concerning whether all or any of the hunting ground graves belong to the South Saami past. There are archaeologists who see the hunting ground graves as being of Germanic or Scandinavian origins (e.g. Baudou 1987; Dalin 1995; Stedingk \& Baudou 2006) while some archaeologists (e.g. Sundström 1989a; 1994; Ramqvist 2007: 165) do not wish to draw any conclusions on the language, ethnic or cultural identity of the grave makers. In her analysis of the hunting ground graves in southern Norway, Gjerde (2016: 224, 228) concludes that the graves are far too heterogeneous to form a unified category, and thus lack the cogency that archaeologists have given to them. She states that no (modern, as I see it) ethnic affiliation can be assigned to them. She proposes that the terms pre-Saami (Norwegian førsamisk) ${ }^{11}$ and pre-Norwegian or pre-Scandinavian (Norwegian førnorsk) be used in connection with archaeological material that cannot be defined as affiliated with a specific ethnic group. (Gjerde 2016: 235.) Gjerde (2016: 234) proposes that even though ethnic identity cannot be seen in the hunting ground graves, the grave goods might reveal other kinds of identities, such as those connected to professions. Later, however, she states that the Pre-Saami remains should also be seen as part of South Saami prehistory, as everything that led to the formation of the South Saami culture is part of the South Saami past (Gjerde 2016: 238-239). 
However, many researchers do interpret the hunting ground graves as belonging to the Saami people (e.g. Serning 1966a; Ambrosiani, Iregren \& Lahtiperä 1984; Sundström 1997; Zachrisson 1997; Fossum 2006). To some extent, the geographical locations and remain structures are indicative of non-Scandinavian sites. The genetic data and language history, as well as the lack of characteristic Germanic jewelry and a continuation from old hunting and gathering culture also point to non-Scandinavian graves. (Hansen \& Olsen 2006: 103.) Hansen and Olsen (2006: 103) state that the graves are Saami and date from the Viking Age onwards; the graves older than the Viking Age belonged to hunter-gatherers whose "hunter identit[ies]" have varied. In other words, Hansen and Olsen (2006) do not comment on the ethnic affiliation of the graves though they do note that the graves might show cultural variation that can be seen in the dwelling area of the Saami during historical times.

I shall not comment on the ethnic affiliation of the graves here but will instead concentrate on the language. I do acknowledge that language is closely connected to ethnicity, but it is only one aspect of ethnicity, albeit a strong one. As I have stated in the introduction, it is known from toponymy (Heikkilä 2011: 68-69; J. Häkkinen 2010b: 59; Aikio 2012: 77-78) and historical lexicology (Piha \& Häkkinen forthcoming) that a form of Saami language was spoken in central Scandinavia during the Early Iron Age. A spoken language requires people who speak it, and it is certain that these people left behind traces of their existence, e.g. graves or remains connected to their livelihood. Therefore, I regard the language affiliation to the graves and other archaeological remains handled in this research as plausible, although it is possible that not all of the graves are affiliated with the Southern Proto-Saami speakers (see chapter 6).

\section{Iron manufacturing sites}

Intensive iron manufacturing has taken place in Dalarna, Jämtland and Härjedalen since the Early Iron Age, and, according to $\mathrm{C}_{14}$ datings, the most intensive phase before the Middle Ages dates to 300-550 CE (Magnusson 1986: 168 fig. 95, 173 fig. 96). The total number of iron manufacturing sites might be more than 2500 , but most of these remain unexamined and are therefore not dated. Of those excavated, six are dated to the Roman Iron Age or Migration Period. ${ }^{12}$ They are all located in Jämtland. (Magnusson 1986.) In addition to this, four sites in Dalarna have been dated to 
these periods (Hyenstrand 1974: 193 table 2), but they have not been further studied. (Table 4.)

\begin{tabular}{|l|l|r|}
\hline \multicolumn{1}{|c|}{$\begin{array}{c}\text { RAÄ } \\
\text { number }\end{array}$} & \multicolumn{1}{c|}{ Site } & \multicolumn{1}{c|}{ Dating } \\
\hline $106 \mathrm{~b}$ & Josvedsviken & $263-634 \mathrm{CE}$ \\
\hline 104 & Tomte 1:2, Josvedsviken & $195 \mathrm{BCE}-207 \mathrm{CE}$ \\
\hline 107 & Tomte 1:1, Åssjön & $120-510 \mathrm{CE}$ \\
\hline 81 & Myre 2:1, Myrviken & $390-707 \mathrm{CE}$ \\
\hline 36 & Präsbordet & $294-526 \mathrm{CE}$ \\
\hline 40 & Ångron & $408-771 \mathrm{CE}$ \\
\hline 24 & Torsång & $20-430 \mathrm{CE}$ \\
\hline 141 & Orsa & $355-555 \mathrm{CE}$ \\
\hline 21 & Järna 1 & $365-565 \mathrm{CE}$ \\
\hline 179 & Järna 2 & $280-630 \mathrm{CE}$ \\
\hline
\end{tabular}

Table 4: Iron manufacturing sites in Dalarna, Härjedalen and Jämtland

Iron manufacturing sites can be located in two different types of environments: forest locations and lake shore locations. The lake shore locations are the older ones, and all the sites from the Early Iron Age fall within the lake shore group (Magnusson 1986: 144 fig. 88). The structures found in Early Iron Age iron manufacturing locations include furnaces for manufacturing iron, charring pits and places to throw the slag and store the iron ore. (Magnusson 1986: 239-261.) The artefacts found in Early Iron Age iron manufacturing locations are few and always connected with iron manufacturing (Magnusson 1986: 58-127).

The iron manufacturing sites are not often interpreted as relating to the Southern Proto-Saami speakers; only Fossum $(2006,143)$ has recently proposed that the Southern Proto-Saami speakers were widely involved in iron manufacture in southern Norrland. She argues convincingly that iron manufacture and domestic animals are connected to and belong to the Southern Saami past. In addition, because of the geographical location of the iron manufacture sites within the traditional South Saami area, I have decided to include them in my material. However, it should be noted that not all the sites were necessarily used by the Southern Proto-Saami speakers. I will discuss iron manufacturing among the 
Southern Proto-Saami speakers of Jämtland and Dalarna in more detail in chapter 6.

\section{Dwelling sites of hunter-gathering character}

All of the known Early Iron Age dwelling sites of hunter-gathering character in the research area are found near lakes and come in form of hearths. The structures resemble dwelling places from the Stone Age and Bronze Age. The artefact finds are different, however. The dwelling sites from the earlier times are usually abundant in stone tools, but artefacts decrease after the transition to the Iron Age, although the structures of the sites stay the same. During the Roman Iron Age and Migration Period, artefact finds are rather rare. (Sundström 1994: 109-111.) Sundström (1994: 111) claims that iron artefacts can be connected to the hunting ground dwelling sites from the Early Iron Age, but I have not been able to detect such a phenomenon from my dwelling site material: no iron artefacts are listed as having been found during the archaeological excavations.

Dwelling sites of hunter-gatherers from the Early Iron Age on are extremely few in number (see Table 5). Only four sites have been excavated: one in Härjedalen ${ }^{13}$, three in Jämtland and none in Dalarna. To my knowledge these sites are the only known dwelling places - new archaeological inventories have not revealed any new ones. The cultural belonging of the dwelling sites has not been discussed much at all.

\begin{tabular}{|l|l|r|}
\hline \multicolumn{1}{|c|}{$\begin{array}{c}\text { RAÄ } \\
\text { number }\end{array}$} & \multicolumn{1}{|c|}{ Site } & \multicolumn{1}{c|}{ Dating } \\
\hline 163 & Ånnsjön, Åre kn & 260-435 CE \\
\hline 309 & Stålavan, Juvuln sjö, Kall sn & $\sim 200$ CE \\
\hline 161 & Vike 2:1, Josvedsviken, Rödön sn. & $322-536 \mathrm{CE}$ \\
\hline
\end{tabular}

Table 5: Dwelling sites of the hunting ground areas

The way of life of hunter-gatherers is a mobile one. They did not dwell in the same place for long, and this may explain the few finds of dwelling sites. Even if the hunter-gatherers practiced iron manufacturing and stayed near the iron manufacturing sites, they might not have left behind detectable traces if the stay was not long enough or if they did not regularly return 
to dwell at the same location. Nevertheless, it is possible that the reason for the lack of dwelling sites is that we have been looking in the wrong places. Are the lake shores the only possible locations for dwelling during the Early Iron Age, or could there be other functional places as well?

Dwelling sites with asbestos-ceramic finds have been found in the northern part of Jämtland and in Swedish Lapland (e.g. Sundström 1994: 110-111). Asbestos-ceramics were already in use during the Bronze Age and Pre-Roman Iron Age, and Sundström (1994: 111) sees a continuity from the Bronze Age to the Roman Iron Age in the use of asbestos-ceramics. However, the asbestos-ceramic sites in northern Jämtland have been dated to the Merovingian Period (Sundström 1994: 110) and are therefore not included in my research.

\section{Other remains}

Other Early Iron Age remains in Dalarna, Härjedalen and Jämtland include hunting pits and remains connected with the Scandinavian culture in the southern parts of Scandinavia and on the shores of the Gulf of Bothnia. The Scandinavian remains consist of grave mounds of the Scandinavian type and sedentary dwelling sites with house remains. The grave mounds are always connected with the sedentary dwelling sites. Even some of the iron manufacturing sites are connected with the Scandinavian dwelling locations. These remains first appear in the research area around 200-400 CE. (Hemmendorff 1989a: 16-17.)

Hunting pits are the most common archaeological remains in the research area. In Jämtland alone there are 10,00o hunting pits of different ages (Melander 1989: 115). They occur as individual pits or in large systems of tens, even hundreds of pits. There is no doubt that many of them have been used by Southern Proto-Saami speakers.

The problem is that the hunting pits are difficult to date. Artefacts suitable for dating have not been found (Melander 1989: 120), and the C14 method is problematic. The same hunting pit can give dates that differ by thousands of years (Wehlin 2016: 240). In addition, the hunting pits often have no datable constructions. (On the dating of hunting pits, see e.g. Halinen 1996.) Some quite reliable datings has been done, however. Most of the C14-dated hunting pits in Jämtland fall between 300 and $1100 \mathrm{CE}$. (Melander 1989: 122.) Four pits have been dated to the Roman Iron Age and two to the Migration Period (Sundström 1994: 111). 
I have decided not to include hunting pits in my research data as they do not contribute much significant material for the purpose of this research. I do acknowledge, however, that the groups who dwelled in and exploited the hunting ground areas - among them Southern Proto-Saami speakers - would have used hunting pits in the area.

\subsection{Archeological categories and find groups}

Most of the artefacts in the data come from graves. Here I will describe the archaeological categories and the find groups in them. ${ }^{14}$ They are also presented in Appendix 4. I have classified the objects into find groups based on the interpretations and discussions of the archaeologists who have performed excavations or other research on the sites included in my research data, e.g. if an object is interpreted as a knife, I have classified it as belonging to the find group of knives; if a structure is interpreted as an iron furnace, it belongs to the find group of furnaces. The archaeological find groups are, in turn, classified into archaeological categories based on the more general function of the find: knives are tools, and thus categorized as tools, while furnaces are structures, slightly more specifically iron manufacture structures, and thus categorized as such. The categorization of the finds is mine, but Serning (1966a), for instance, has categorized finds on basis of their function in her description of the Iron Age in Dalarna.

The fact that the objects that make up the find groups may have meant more than they seem to modern researchers should not be ignored. They may have had a symbolic status or religious meaning, or they may have represented power or professions, among other things. Finds in graves are particularly difficult to interpret as they are found in a religious context: are they or do they represent commodities used in everyday life, or is their function solely religious? In this research, I will interpret them as commodities that are or represent artefacts required in everyday life. Even if they had only religious or ritual meanings, they may have been referred to using similar words as those used for the corresponding everyday artefacts: if there is a knife-like artefact in a grave, it could have been called a knife despite its sacred or profane nature in the society. (For more details, see chapter 2.1.) 


\section{Artefacts connected with animal handling}

The only artefact connected to animal handling other than hunting is a horse shoe fragment from the cemetery of Vindförbergs udde. It was found in grave number 29 .

\section{Clothing and jewelry}

I have decided to place the find groups of clothing and jewelry together, as it is not easy to tell the difference between a clothing accessory and a piece of jewelry. Furthermore, actual clothes are rarely found during archaeological excavations. The main category of clothing and jewelry is divided into three subcategories: clothes with a find group of fabric, jewelry and accessories, and other artefacts, which includes a bird-shaped bone artefact.

In the data, there are only two pieces of fabric, one from the cemetery of Smalnäset (grave number 18) and the other from Krankmårtenhögen (grave 37). They were both found in the same context with bronze artefacts. As far as I know, no analysis has been made of the fabric to determine its material composition.

Eight brooches, fibulas and belt buckles have been found in the following cemeteries in Dalarna: Örviken (three cross-shaped bronze fibulas in grave 5), Södra Getryggen (grave 6) and Vindförberg (an iron brooch from grave 2, fibulas from graves 16 and 34, an iron belt buckle from grave 8). The fibulas have a western distribution and therefore show contacts with Norway (Hyenstrand 1987: 120). A round bronze brooch has been found in Södra Getryggen. The brooches and fibulas are often a very good indicator of the age of the grave, as there is an established brooch typology.

Along with bronze brooches and fibulas, the research data contains other bronze jewelry. In Smalnäset (grave 18) and Hästnäset (grave 4), bronze spirals have been found. In addition to these, one of the beads is a bronze spiral bead, found in grave 37 in Krankmårtenhögen. Bronze rings or ring fragments have been found in Örviken (graves 1 and 5), Hästnäset (grave 1) and Vindförberg (graves 3 a and 8). Buttons made of bronze are known from Hästudden, as well as a half of a bracelet from Vindförbergs udde. A bronze pin was found in Örviken grave 5. The iron clothing accessories other than buckles, brooches and fibulas are mountings of a belt from Vindförberg (graves 16 and 17) and iron pins from Vindförberg (grave 39). 
Jewelry and accessories made of bones include combs, a hairpin, a bird-shaped artefact and pendants. The bird-shaped artefact in Hästnäset (grave 3) may not be a piece of jewelry at all - it is difficult to determine in which category it should be placed. Two pendants were found, also in Vindförberg. One of the pendants was found in the same grave (number 16) as a bone comb. The hairpin is from Klevsand.

Bone combs are a common grave good find: fragments have been found in 14 graves in four grave sites and cemeteries. Most of them, 11 in total, are from the cemetery of Vindförbergs udde. The other find places are Klevsand, Smalnäset and Örviken.

Beads come in glass, amber and, as we have seen, bronze. Glass beads are found in Finnäset and in two graves in Örviken ( 1 and 5). The Örviken graves have been mentioned many times above, and they are rich in grave goods. In grave 1, the beads are colored blue. The beads of grave 5 are in fragments. They are made of frit and glass.

\section{Glass artefacts}

The glass beads were discussed above, and no other identified glass artefacts are known from the grave sites or other locations included in the data. However, in the excavated grave of Klevsand, smelted green glass was found. It is unidentifiable, but it is possible that it has also been a bead or beads.

\section{Hunting tools}

Hunting tools are rare in the data. Some of the weapons might have been used as hunting tools, but it is difficult to determine which ones. Here, I shall list only the arrowheads as hunting tools. It is likely that they were first and foremost meant for hunting (Lipping 1981: 22). I have, however, listed them as weapons as well. Arrows of different material or size and shape may have had different purposes, e.g. different animals could have been hunted using different kinds of arrows (Lipping 1981: 12). I will not discuss the different functions here in further detail as it is not relevant from the perspective of the aims here: the PScand loanword stratum does not have a word for any type of arrow, and therefore it seems that arrows were not central artefacts in contacts between Proto-Scandinavian and Southern Proto-Saami speakers. 
The arrowheads come in three materials: flint, bone and iron. The only flint arrowheads in the material were found in Finnäset. The iron arrowheads are more common, as nine have been found in three locations. Two from Fulufället have been found with a spearhead. The one from Hästnäset was the only grave good found in the grave 2 besides bones and antlers. The rest come from Vindförbergs udde (graves 15, 19, 21, 25, 34 and 35b). Most of the graves with iron arrowheads are very rich in other artefacts.

Arrowheads of bone are the most frequent type. They come from 16 graves but have been found only in the cemetery of Vindförbergs udde. Most of the graves contain more than one arrowhead, but they are often the only grave goods.

\section{Iron manufacture and forging}

Archaeological material connected to iron manufacture and forging could be classified under two main archaeological categories: structures or tools and working materials, but as it is in my interest to examine the relation of the Southern Proto-Saami speakers to iron manufacture, I have decided to classify iron manufacture and forging as a separate main category and divide it into two subcategories: iron manufacture and forging-related structures and tools.

The structures at iron manufacturing sites consist of furnaces, charring pits, iron ore storage locations and slag dump areas. The artefacts found at the sites consist of iron slag (Josvedsviken 106b and 104, Åssjön, Myrviken, Präsbordet and Ångron) and iron ore (Josvedsviken 104, Åssjön, Myrviken, Präsbordet, Ångron).

The grave finds that can be classified in this category are a hammer, plier fragments and possibly iron bars found in the grave of Hästudden. These are more likely related to iron forging than to iron manufacturing.

In addition to the above-mentioned, another grave must be considered in relation to iron manufacture. The lone grave of Josvedsviken is located near the iron manufacturing sites of Josvedsviken. One of the iron manufacturing sites, Josvedsviken 106b, is contemporaneous with the grave. The grave is located near an old hunting ground dwelling site. It is possible that the actual dwelling site is not contemporaneous with the grave, but there is an asynchronous fireplace that dates to the Migration Period along with the grave. The filling of the grave is iron slag and burnt iron ore, and it makes the grave blaze red. No artefact finds were detected, only bones of swine and capercaillie. No human bones were found either. (Magnusson 1986: 71.) 


\section{Osteological finds}

I have decided to divide the osteological material into four archaeological categories instead of handling it as one general category. This renders the analysis of the bones within the theoretical model simpler. The categories are human bones, animal bones, unburnt elk and reindeer antlers, and those bones for which it is not possible to determine whether they are animal or human. Animal bones are divided into three subcategories. (Appendix 4.) I will not look at the human bones more closely here.

\section{Unburnt antlers}

Elk and reindeer antlers and the cranial parts to which the antlers are attached make up the most common of the osteological finds after the human and indeterminate bones. Instead of including them as one of the subcategories of animal bones, they are classified as a separate archaeological category. The antlers in this category are unburnt and are not found in the graves but rather on them. Those (burnt) antlers that are found in the graves are classified in the find group of elk or reindeer in the subcategory of wild animal bones.

Unburnt antlers have been found on 18 graves in three different cemeteries. They are most common in Krankmårtenhögen, as 15 of the graves with antlers are found there. All of the graves with antlers are from triangular stone settings. Only in one case in Krankmårtenhögen (grave 37) were any grave goods other than bones found in the grave, although some of the elk bone graves also had resin from a box where the human bones had been placed. As mentioned earlier, the antlers are dated to be either contemporaneous with the youngest graves in the cemetery or younger than the cemetery (Olofsson 2010: 100; Welinder 2008: 36, 60).

At Smalnäset, antlers were found on two graves (23 and 31). Both graves are triangular in form. No finds other than bones were detected. There are also antlers in one grave in Halvfariudden (grave 2), but the find context is uncertain as the antlers and cranial parts were found in the grave's filling. The grave is round in shape and did not contain any artefacts. Graves with antlers deposited on them are also found in Swedish Lapland, namely in Tärna parish in graves near Lake Abelvattnet and Lake Gräsvattnet (Zachrisson 2009: 139). They date to around $1 \mathrm{CE}$ (Gräsvattnet) and $500 \mathrm{CE}$ (Abelvattnet) (Zachrisson 2009: 139). 


\section{Animal bones}

The archaeological category of animal bones consists of three subcategories and 13 find groups. One of the subcategories is indeterminate animal bones. These are bones that can be identified as animal bones, but for which no more precise analysis is possible. Indeterminate animal bones are found in 14 graves in three cemeteries (Smalnäset, Halvfariudden and Vindförberg). The two other subcategories are bones of wild animals and bones of domestic animals. In some cases, it is challenging to detect whether the (wild) animal bones are from the graves or from earlier Stone Age layers under the graves (e.g. Zachrisson 2011: 198).

Elk bones make up the most common find group in the subcategory of wild animals. Elk is found in 14 graves in four cemeteries: Hästnäset (graves 1, 2 and 3), Krankmårtenhögen (graves 1, 2, 10, 28, 33 and 50), Smalnäset (graves 9 and 16) and Vindförberg (graves 3a, 4 and 24). In Hästnäset, the elk bones also include burnt antlers and cranial parts. In grave 50 in Krankmårtenhögen, a cranial part without antlers was found. In Smalnäset and Krankmårtenhögen, no grave goods other than bones were detected, but in Hästnäset some artefacts were found.

Reindeer bones are rather rare in the data with only two occurrences, one in Smalnäset (grave 16), the other in Krankmårtenhögen (grave 1). They both come from graves with elk bones, and the Smalnäset grave is rich in other animal bones as well. None of the bones in the Smalnäset grave have been identified as human. Both graves with reindeer bones lack artefacts.

Bear bones are another common find group. Bones of bear were detected in nine graves at the cemeteries of Krankmårtenhögen (graves 2 and 28), Smalnäset (12) and Vindförberg (3a, 6, 7, 12a, 12c and 15). In Vindförberg, the bear bones were, in fact, bear fangs in three cases. In Smalnäset, the bear bones were the only identified osteological find, and the grave lacked artefacts. The graves in Krankmårtenhögen contained other animal bones as well as human bones.

Bones of beaver (Smalnäset 16, Vindförberg 3a), capercaillie (Josvedsviken 161), fish (Vindförberg 3a, 7, 41 Hästudden), loon (Krankmårtenhögen 2), red deer (Krankmårtenhögen 2) and an unidentified ruminant (Smalnäset 16) were detected in graves. All the graves contained other animal bones, and the graves in Dalarna were quite rich in other grave goods as well. 
Bones of domestic animals were found in eight locations. The bones include dog (Hästudden, Vindförberg 3a), horse (Hästnäset 2, Hästudden?), sheep/goat (Klevsand, Krankmårtenhögen 10, Ånnsjön), and swine (Josvedsviken 161, Tjuvholmen). Jensen (1989: 66) notes that the sheep/goat bones at the dwelling site of Ånnsjön are connected to relatively recent animal husbandry in the area. He does not, however, provide any explanation for this hypothesis. In many cases, artefacts were found in connection with the domestic animal bones. The only other artefact that might indicate animal husbandry and agriculture in the data is the spindle whorl from Vindförberg 12a. It may tell us about the spinning of wool or linen (see below).

\section{Tools and working materials}

The archaeological category of tools and working materials consists of 14 find groups, which are categorized into three subgroups: working material, tools and parts of tools or artefacts. Knives are the most common tools: they have been found in nine graves located in Finnäset, Hästnäset (grave 1), Tjuvholmen, Vindförbergs udde (graves 1, 5, 6, 14 and 19) and Örviken (5). The other artefacts in these graves range from hunting tools and weapons to clothing and jewelry. All the knives have been found in Dalarna except for the one in Tjuvholmen.

Awls have been found in three graves, one in the same grave as the knife at Örviken (5) and two at Vindförberg. Sockets have also been found in three graves, all from Vindförberg. The rest of the tools include a scraper, a hammer, pliers, scissors, a bronze chisel and firesteel. They were all found in one grave.

Bushings are made of bronze or iron and have been found only at Vindförbergs udde. Staples are also found in iron and bronze, and they come from Södra Getryggen, Hästudden and Vindförberg. Bushings, staples and sockets do not necessarily belong to the archaeological category of tools and working materials. They could be parts of jewelry, weapons or other artefacts that have not been detected in the data because they have decayed before the archaeological excavations. However, most bushings and sockets likely belong, for example, to knives, and staples could be seen as working material.

The only tool connected to agricultural activities is a spindle whorl. It was found in grave number 12a in Vindförbergs udde along with a bone comb. 
The stone tools that are included in the data come from the dwelling site of Annsjön. They are scarce in comparison to older Stone Age dwelling sites and consist of two scrapers made of quartz, one made of flint and stone waste. Jensen (1989: 66) argues that most of the dwelling site is much older than the dated fire place $(260-435 \mathrm{CE})$, but again, he does not provide any explanation for why he thinks so.

\section{Weapons}

Weapons have not been popular finds in hunting ground graves or other sites connected with the hunting-gatherer societies of Dalarna, Härjedalen and Jämtland. Arrowheads are the most frequent find group. I have described them above as hunting tools.

In addition to the arrowheads, there are four iron spearheads, one shield boss and one bronze pommel. Two of the spearheads are from Vindförbergs udde (graves 8 and 15), while the other two are from Fulufället and Tjuvholmen. The Fulufället spearhead was found with arrowheads of iron, and the Tjuvholmen spear was found in the same context as the only shield in the data. It must be noted that the spearheads are not similar to one another in form. Spearheads can often be used to date graves as the form of the spearhead has varied over time. The bronze pommel is from Vindförbergs udde (grave 19).

\subsection{Summary}

Even though the hunting ground graves in Dalarna, Härjedalen and Jämtland are considered to be related to each other, it is clear that they differ a great deal. Their geographical contexts are similar, and the structures resemble each other from cemetery to cemetery, but the grave goods vary from grave to grave and cemetery to cemetery. It seems to me that the people who used the cemeteries had similar ideas about life after death and how to ensure that the deceased is able to enter the realm of the dead. The same ideas about items needed in the realm of the dead are seen in Dalarna, Härjedalen, Jämtland and generally in pre-Christian graves: the dead seem to have received goods that they likely needed during their life. The livelihood was also likely quite the same: hunting, fishing and gathering. Iron manufacture and domestic animals also gain significance during the Early Iron Age, perhaps because of the growing iron industry (Fossum 
2006: 143; see also chapter 6). ${ }^{15}$ The grave makers in Dalarna were closer to the Scandinavians in the south and possibly had more (trading) contacts with them. These would result in more products coming their way, which would explain the richer grave goods. Scandinavian speakers might also come to Dalarna for hunting rather than go further to the north. Hunting activities would also result in more intensive contacts and goods coming to the area.

Closeness to another people and intensive contacts with them would probably also lead to an increased number of conflicts. Weapons are not abundant in the finds, but most of them - all but one spearhead and a shield boss from Tjuvholmen, Jämtland - are found in Dalarna. They would indicate contacts and conflicts with others within or close to the area. The spearheads and shield boss from Vindförberg point to (southern) Scandinavia, and the bronze pommels have counterparts in Öland but also in Ostrobothnia, Finland (Lipping 1981: 9, 10). The weapon finds from Tjuvholmen were in bad shape and no comparison with finds from other areas can be made (Magnusson 1986: 74). Perhaps the rich grave goods and especially the Scandinavian jewelry, such as those items found in the cemetery of Vindförberg, also indicate stronger assimilation between the Scandinavian and Saami speakers at an early date.

The animal bones in the graves are more difficult to explain. Perhaps it was believed that the dead would take them to the realm of the dead as sacrifices or as a kind of payment to deities, or perhaps it was food for their journey to the underworld. It might also have something to do with a kind of animal totemism or forefather beliefs: The bear cult and beliefs about humans transforming into animals such as bears and wolves are known from later Saami folklore (e.g. Pentikäinen 1995: 95, 97-104) and can also be seen in the form of bear graves in the archaeological material (e.g. Myrstad 1997). They may well have their roots in the Early Iron Age culture: perhaps the animal bones would in some graves indicate the dead's close contact with the buried animal. The graves with animal bones but without human bones are particularly interesting from this perspective. If it was, for some reason, impossible to bury the person, perhaps an animal was buried instead (Ambrosiani 1984: 54; Zachrisson 1992: 111). However, there is not much proof that animal bones were buried in an immediate context with human bones. Further, most animal bones might have been from the Stone Age dwelling site layers, for example in Krankmårtenhögen. Olofsson $(2010,110)$ suggests that the antlers and cranial parts of reindeer and 
elk are a way of "communicating a message of regeneration towards the animal persons with whom the human persons constantly interacted".

It is not easy to determine the language spoken by the buried or the grave-makers based on the archaeological material. However, it is not realistic to interpret them (only) as graves belonging to Proto-Scandinavian speakers when we know that there were other people on the hunting grounds too. What is more, grave customs described as belonging to Scandinavian-speaking culture are already known, even from areas close to the hunting ground graves. The inland hunting ground areas of Jämtland and Dalarna have traditionally been an area utilized by the Saami speakers and their (non-Saami-speaking) ancestors, probably already before the Scandinavian speakers. I will next combine the two data sets - archaeological and lexical - to see what the combination reveals about the Southern Saami past.

\section{Combining the lexical and archaeological material}

The combination of lexical and archaeological material is presented in Appendix 4. First, I will discuss the uncorrelative material and then proceed to the correlative archaeological and semantic categories. Then I will consider the problems that arose when I applied the theoretical model to my data. Finally, I will evaluate the functionality of the theoretical model.

\section{I. Uncorrelative semantic and archaeological categories}

The lexical finds in the categories of action processes, adjectives, conditions and changes, flora, natural phenomena, relations in space and time, terrain and landscape, trade, water and water systems, as well as the category of other words, refer to phenomena that cannot be detected in the archaeological material. I have included these semantic categories in the model (Appendix 4) but I have not specified the lexical finds within them. The semantic categories of food and cookery and religion and beliefs could also be listed here. There are no archaeological categories that could correspond to these semantic categories unless animal bones are counted as food and cookery and grave structures as part of religion and beliefs.

The semantic category of flora might correspond with archaeological material if there had been any palaeoecological investigations performed at the archaeological sites or near them. Unfortunately, to my knowledge, 
none have been taken from the sites in the research data, or if they were taken, they did not provide any valid information. ${ }^{16}$

Terrain and landscapes as well as water and water systems can also be detected in the archaeological material from the perspective of landscape archaeology or spatial analysis of the remains: how the remains are located in relation to one another and the landscapes of the area. In this research, landscape archaeology or spatial analysis was not applied in a specific enough manner and therefore the archaeological perspectives connected with these two semantic categories are not discussed.

The semantic categories of humans as members of society, trade and vehicles and travelling can hypothetically be seen in the archaeological material. Humans as members of society can be detected in graves: some of the grave goods can be interpreted as status symbols. Artefacts showing connections to the southern Scandinavia may even speak of status symbols that were affected by the Proto-Scandinavian speakers. In my combined material, however, there are no straightforward correlations that could reveal structures of the Southern Proto-Saami-speaking society and the Proto-Scandinavian speakers' influence on it. The semantic category of trade is only secondary, and has one word, laajkoe 'debt', an abstract concept that cannot be seen in the archaeological material. However, many of the words with a primary meaning in other semantic categories might indicate trading with the Proto-Scandinavian speakers, e.g. aarhtse 'eagle' and faala 'whale'. In the archaeological material of this research, no remains have been detected that can be correlated with these words. No archaeological remains for vehicles have detected in this research either.

Three of the archaeological categories (glass artefacts, iron manufacture structures and weapons) do not have counterparts in the semantic categories. Glass artefacts include only the find group of beads, and these are mostly made of frit. The PScand loanword stratum in SaaS does not have a word referring to beads. The same applies to all of the artefacts that are identified as weapons in the data.

\subsection{Correlative semantic and archaeological categories}

All of the archaeological categories that were not mentioned in chapter 5.1 correlate with at least one semantic category and vice versa. However, there are many correlating categories in which not many or any of the finds correlate with one another. Thus, not many conclusions can be drawn on the 
basis of categories alone, with the exception of the idea that the linguistic data generally represents the same domains of life as the archaeological data. The best correlations are drawn from the following combinations (semantic category / archaeological category): domestic animals / domestic animal bones; pieces of clothing / clothes; reindeer (and elk) / unburnt antlers and cranial parts of reindeer (and elk); tools, pieces of clothing, fabric / tools.

In addition to these, there is a hypothetical correlation between body parts and human osteological material. However, to correlate them does not provide any relevant information on the contacts between the Southern Proto-Saami and the Proto-Scandinavian speakers. I have not analysed the human osteological material to any extent. Therefore, I have not listed the lexical finds and archaeological find groups here.

\section{Work-related data}

The semantic main category of work-related words coincides with the archaeological main category of tools and working materials (and all of its subcategories). The archaeological and semantic subcategories also coincide but for two exceptions: On the archaeological side, there is no counterpart for the semantic subcategory of working, as the only word in the category is the verb aalhtedh 'to prepare; to work with animal skin'. In turn, there is no counterpart for the archaeological subcategory of parts of tools or artefacts. There are no archaeological or semantic categories that would fully coincide, meaning that all of the lexical finds in the category would correlate with all the archaeological finds of the corresponding category.

There is no multidisciplinary evidence of iron manufacture in the research material: no words implying iron manufacture have been borrowed from PScand into SaaS. However, it is not entirely out of the question that the word aassjoe 'hearth in a smithy' could be connected to the archaeological remains of furnaces. At least the iron hammer, pliers and iron bars found in the grave at Hästudden can be related to the hearths in smithies.

The words nejpie 'knife' and aavtjoe 'edge of a knife' correlate with the (iron) knives that appear in the grave material of the archaeological data right after the first hunting ground grave phase of the Krankmårtenhögen and Smalnäset cemeteries. Flint tools might be connected to the possible 
PScand loanword dytnije 'flint; flintstone used as a firesteel' discussed by e.g. Qvigstad (1893: 129) and Sammallahti (1998: 128). However, no PScand reconstruction is given for the word and therefore it is not included in my data.

The rest of the lexical finds and archaeological find groups within the categories of tools do not correlate. It is no surprise that e.g. riejhpe 'rope, cord' is not detected in the archaeological sites, as artefacts of organic material are not usually preserved for long in the ground. However, it is interesting that the data includes words for axe, tin and silver, while the corresponding archaeological find groups are missing. Most of the artefacts in the data are found in graves. It is possible that axes, tin and silver were not objects used as grave goods. Axes, for example, might have been in use at dwelling sites only, and as the dwelling site material is scarce, no axes are found in the data.

In turn, the lexical finds for e.g. scissors and chisels are lacking, but the archaeological find groups are present. These were not very common tools at the time, as there is only one pair of scissors and one chisel in the data. It is possible that there were words for them that disappeared once the tools were no longer used among the (Southern Proto-)Saami speakers. Yet another conclusion could be drawn from examining where the SaaS words for the objects originate and what the etymology might tell about them.

\section{Agriculture and animal husbandry}

The archaeological subcategory of domestic animal bones can be connected to the semantic category of agriculture and animal husbandry. Many of the find groups in the archaeological category are reflected in the lexical finds: Bones of sheep/goat are referred to using the words gaajhtse 'goat', saavtje/saavhtse 'sheep', laampe 'lamb' and vïerhtse 'ram'. The words täjhkoe 'female dog' and svijnie 'swine' and the archaeological find group of dog and swine bones can be also correlated. There is no reference to horses in PScand loanword strata in SaaS, but horse bones and a part of a horseshoe are among the archaeological data. In turn, there are words for cow and calf of a cow but no archaeological material of cows.

Agriculture cannot be seen in the archaeological material of the research: there are no artefacts connected to planting or harvesting, and no palaeoecological samples have been taken. However, there is a spindle whorl in the archaeological material, which points to agricultural 
activities. The words referring to cultivation are scarce, though the words for food produced by agricultural means are plenty. These might indicate either agricultural activities among the Southern Proto-Saami speakers or the purchase of agricultural products from Proto-Scandinavian speakers. The word aernie 'hearth' in the semantic category of buildings and constructions, as mentioned before, might be an indicator of agriculture or exploitation of agricultural products such as flour for baking bread. However, there is no archaeological material about baking ovens of this sort in the data used in the research.

There are lexical finds in other semantic categories that might point to sedentary life among the Southern Proto-Saami speakers: ståapoe 'house, cottage' and buvrie 'storage building' in the semantic main category of buildings and constructions. Unfortunately, no archaeological evidence for house or storage remains is present in the data. However, there are house remains traditionally connected to the the Scandinavian culture very close to the hunting ground areas. Further, Stedingk and Baudou (2006: 194) mention that shielings are found in the southern parts of the hunting ground area of inland Scandinavia, but I have no knowledge of those in the research area.

\section{Clothing and jewelry}

It is notable that there is a large variety of jewelry and accessories in the archaeological data but no PScand loanwords that refer to them. As stated above, Hansen and Olsen (2006: 103) mention that there is a lack of Germanic/Scandinavian jewelry in the archaeological material. However, Lipping (1981: 12-16) notes that some of the artefacts are Scandinavian types, although she concentrates mainly on the cemetery of Vindförberg in Dalarna; the lack of jewelry is apparent in Härjedalen and Jämtland.

The vocabulary for clothing is larger and is reflected in the archaeological find group of fabric. One of the words, vaanhtse/faahtse 'mitten' refers to woolen clothing; vaarese 'homespun fabric' and vaarjoeh/vaarjese 'clothes; fabric' do not specify the material. Lijnie refers to shawls and scarves but the cognate in ON, lin, means linen. The two pieces of fabric found at the archaeological excavations at Smalnäset and Krankmårtenhögen have not, to my knowledge, been analyzed. They are also problematic from the linguistic perspective because of the early dating (see chapter 6). There is, however, a tool connected to weaving: a spindle whorl. Southern 
Proto-Saami and Proto-Scandinavian contacts certainly involved weaving, as there is both archaeological and lexical data referring to it. The lexical finds and the archaeological find group can also be seen as further evidence of domestic animal husbandry among the Southern Proto-Saami speakers. It is likely that the Proto-Scandinavian speakers sold shawls made of linen to the Southern Proto-Saami speakers, which influenced the semantic change of the SaaS word to shawl.

\section{Reindeer}

The bones of (female) reindeer may be connected with the lexical find råtnoe 'female reindeer'. Aevsie 'cranial parts around reindeer (or elk) antlers' has straightforward counterparts in the antlers and cranial parts found in the hunting ground graves.

The rest of the lexical finds do not have counterparts in the archaeological find groups. Many of the words refer to phenomena and concepts that are impossible to detect in archaeological data, e.g. eajma 'reindeer doe who wanders where it wants'. In theory, it would be possible to find remains of gaertie 'reindeer corral' and haame 'antler-less reindeer'. It should be kept in mind when combining the reindeer vocabulary with archaeological material that the semantic development of reindeer-related words has been drastic, and it is possible that the modern meanings of the words differ from those of the Roman Iron Age and Migration Period.

\section{Wild animals}

There is evidence in the lexical data pointing to marine animals having been part of the contacts between the Southern Proto-Saami and ProtoScandinavian speakers. It is probable that marine mammals, such as whales and train oil, as well as seashell pearls and even fish, were significant as trading goods - but the Proto-Scandinavian loanwords in SaaS do not reveal whether the Southern Proto-Saami speakers were the sellers or purchasers of these marine products. Similarly, eagles and falcons might have been desirable trading goods, but again, it is difficult to determine the direction of the trade. The archaeological material of my research on marine animals and birds is scarce - there are remains of (unidentified) fish, but falcons, eagles, whales, seashells and pearls are missing. However, there is some analogical material elsewhere in Saepmie indicating, for 
example, exploitation of whale train oil (e.g. Nilsen 2016), and some of the material should undoubtedly be connected to Saami speakers.

Other lexical finds in this category refer to insects, and it is no surprise that these are not found in the archaeological material. Most of the animal bone find groups found in the data do not coincide at all with the lexical finds.

\subsection{Problematic categories, find groups and lexical finds}

There are some problems with the basic theoretical model. The biggest flaw is - and this does not have anything to do with the model itself but with the different nature of archaeological and lexical data - presented above in the form of semantic categories that are impossible to detect in archaeological material. There are other problems as well, but the theoretical model is quite flexible and can be applied to problematic material.

One of the problems is the correlative semantic and archaeological categories in which none of the lexical finds or archaeological find groups correlate. The hypothetical category correlations are (semantic category / archaeological category): animal handling / artefacts connected with animals; hunting and fishing / hunting tools. In addition, the categories of buildings and constructions / structures; wild animals / wild animal bones do not correlate except in the case of a few words. This same challenge is faced even within those categories that correlate better. For example, the semantic subcategory for domestic animals correlates very well with the archaeological subcategory of domestic animals, but there is no counterpart for every single word or find group.

Lacking lexical finds or archaeological find groups - if they can even be called lacking - are not an actual problem, as we get additional information about the culture: we do not have a word for horse but there are archaeological remains of horses. Because the lexical data prove the presence of other domestic animals and there is archaeological evidence of horses in the data, it is convenient to assume that Southern Proto-Saami speakers knew of horses. ${ }^{17}$ The words referring to cows prove that the Southern Proto-Saami speakers were familiar with cows as well.

It is also essential to consider the fact that the categories including domestic animal names and archaeological finds are etic categories of the researcher. It is entirely possible that the emic category of the Southern Proto-Saami did not include cows: the words were known because of the 
intensive contacts with Proto-Scandinavians who kept cattle. The same applies to many other words without counterparts in archaeology: The Southern Proto-Saami speakers may have needed words for e.g. whales or houses because they were an important part in the neigbouring ProtoScandinavian culture.

The lexical finds within the categories that mostly do not correlate with the archaeological find groups reveal that the Proto-Scandinavian language did have some kind of influence on the phenomena around the word. That said, it is impossible to detect the nature of that influence. If there is, in turn, archaeological material referring to a phenomenon, but no word found among the PScand loanwords, this may indicate that the contacts did not involve the phenomenon seen in the archaeological material. Or, if there is solid evidence in the archaeological material about contacts towards a Proto-Scandinavian-related culture, it might mean that there has been a PScand loanword referring to the phenomenon, but it has disappeared from SaaS at some point during the history of the language. It is also possible that no new word was borrowed because there was already a suitable word in Southern Proto-Saami for the new phenomenon. An interesting phenomenon is the furnace structures found in the archaeological data. There is no word for a furnace in the PScand loanword strata, and according to the SaaS dictionaries, no word for the structure is found in the language at all. Has it disappeared, or has there never been a word for furnaces? The latter seems unlikely, as iron manufacture was very intensive in the dwelling areas of South Saami speakers from the Early Iron Age all the way to historical times (Magnusson 1986: 168-178).

There are also cases in the data in which an archaeological find group or even (sub)category coincides with a lexical find but the semantic and archaeological categories do not coincide. One case is aajmoe 'the other world (i.e. the realm of the dead)'. If the word aajmoe had a very concrete meaning of cemeteries and graves being the realm of the dead, or at least the passage to the realm of the dead, there could be a correlation between the subcategory of grave structures and the lexical find aajmoe. Nevertheless, the correlation is vague, as neither the archaeological category nor the word reveals anything specific about the phenomenon, and the word may have a more abstract meaning as the realm of the dead. In addition, in Scandinavian languages, the cognate word has the meaning of 'home', and in PScand the reconstructed meaning is thought to be 'village' ( $>$ Sw hem 'home') (Sammallahti $\left.1998,227^{18}\right)$. The change in the semantics towards a religious meaning 
may have taken place internally within the (Southern Proto-)Saami culture; the word might have been borrowed in its original meaning. The example shows that it is necessary also to compare lexical finds with archaeological find groups and categories regardless of semantic category. These sorts of problems only concretize how the categories are strongly an etic system.

Another problematic case concerns the word aevsie and the semantic category of religion and beliefs. There is no archaeological data in my research that could be easily detected as religious other than the grave structures (and the finds in the graves because of their context). Aevsie and the reindeer antlers are one possible religious correlation, but as the word does not have religious connotation in modern SaaS, I have classified it within the semantic category of reindeer and reindeer husbandry. Perhaps here the archaeological material can reveal a lost, emic religious (connotative) meaning that cannot be seen in the modern semantics of the word.

There is no example of a correlation between a semantic category and a single archaeological find group. However, it does not mean that such a phenomenon would not exist in other data, especially because the hierarchy of semantic categories within an ontology is flexible.

Finally, most of the more precise correlations are made between subcategories. Therefore, main categories also correlate because the subcategories are always included in main categories. This raises the question of whether the main categories are needed in the model at all. However, there are some cases where, for example, a meaning of a lexical find is so broad that it best correlates with a main category, e.g. bearkoe 'meat for food' correlating with animal bones. Categorizing finds into main categories and subcategories also makes it easier to perceive the phenomena around the lexical finds and archaeological find groups.

\subsection{Summary}

There are clear advantages to the theoretical model for combining archaeological and lexical material. The model reveals correspondences and uncorrelative objects within the two sets of data and can be used to verify some matters that cannot be concluded with certainty based only on archaeological or lexical data. The material associated with domestic animals is a strong example of the functionality of the model.

It seems that, when comparing lexical strata to contemporaneous archaeological material, the strong trends that spread by contacts stand out. 
Along with the domestic animals, iron products - particularly knives - are detected in both materials of this research. Those objects and words that seem to relate to these phenomena but are seen only in one of the two sets of data add to the reconstruction of the culture and language contacts of the Early Iron Age.

Sometimes the correspondence between a word and an archaeological object can be misleading. Therefore, a careful analysis of all the correspondences must be made: the spatial and temporal contexts should be considered for the material remains, and the language historical contexts for the words. As an example from my material, one can consider the problems with aevsie 'antlers and cranial parts of reindeer/elk' and the corresponding archaeological material (see chapter 6).

In the majority of cases, the archaeological and lexical data do not correspond with one another. This should be seen not as a problem, however, but as an advantage. The two sciences coincide in the nuclear areas of contacts. The more peripheral areas are not represented in both sets of data, but they bring more knowledge to the general view of the prehistorical period under examination.

Also, when combining a loanword stratum with archaeological material, not everything in the simultaneous archaeological material necessarily refers to contacts with those from whom the words are borrowed. There are areas of life seen in the archaeological material which the loanword donor language did not affect at all. Those areas reveal nothing of the cultural and language contacts under scrutiny. Nevertheless, they do provide information about the culture of the speakers who have received the loanwords. It is also possible to have cultural contacts without borrowing words. An artefact type could be new but there could already be an old word suitable to refer to the new artefact type. Some of the uncorrelative objects in the material might very well be phenomena of this kind, for example the uncorrelative data of jewelry.

However, it would be essential to examine the uncorrelative material in more detail. From where do the words referring to jewelry and accessories, weapons and other archaeological material originate? In this article, I concentrate on the contacts between Proto-Scandinavian and Southern Proto-Saami and will not discuss these questions further here, but they are certainly of interest for the holistic picture of the South Saami prehistory. 


\section{New perspectives on the Early Iron Age in the hunting grounds in Jämtland and Dalarna}

Combining the lexical material of North-West Germanic and (early) Proto-Scandinavian loanword strata and the archaeological material of the hunting grounds in inland Scandinavia reveals new perspectives on the prehistory of today's South Saami speakers. The results presented here will concern matters of livelihoods and trade that were affected by contacts with Proto-Scandinavian speakers. In addition, a new theory about an extinct Paleo-European language in southern Norrland during the Early Iron Age will be tentatively discussed.

\section{I. Domestic animals among Southern Proto-Saami speakers}

A few years ago, Stedingk \& Baudou (2006: 194) stated in an article based on their study on pollen analysis that the "inland subsistence in central Norrland [Jämtland, Härjedalen, Ångermanland] during the Iron Age was characterised by diversity and flexibility, not by a uniform and static hunter-gatherer culture" and that "extensive forest grazing was widespread throughout central Norrland". The archaeological material and NwG and PScand loanword strata of my research clearly supports their statement. The ethnic and language affiliation Stedingk \& Baudou assign to the archaeological material is, however, problematic. They are not straightforward concerning matters on ethnicity and languages, but they do indicate that the grazing lands, graves with domestic animal bones and iron manufacture sites, as well as the shieling finds in Dalarna and Jämtland, could not have belonged to a Saami-speaking culture (see also Fossum 2006: 90, 140).

However, linguists (e.g. Heikkilä 2014: 240) have already proposed that the predecessors of South Saami speakers in the Early Iron Age in Scandinavia practiced animal husbandry. Even archaeologist Fossum (2006: 143) agrees with this. Aikio (2012: 80) has noted that the domestic animal vocabulary borrowed from PScand is a result of the trade network. As my study has shown, the vocabulary referring to domestic animals, borrowed from NwG and PScand, is large, and the words correlate with the domestic animal bones found in the hunting ground graves. Furthermore, SaaS has borrowed a word for a shieling or storage building (buvrie) from PScand, and even a word for a house or cottage (ståapoe) originates from PScand. These concepts were clearly received from Proto-Scandinavian speakers, 
but they do indeed suggest that Southern Proto-Saami speakers practiced some sort of agrarian way of life in the Early Iron Age. Some of them might have settled down in houses in order to concentrate on domestic animals as their main livelihood (see also Heikkilä 2014: 240).

\subsection{Reindeer pastoralism}

In addition to domestic animals, particularly the lexical data of my research reveal another important livelihood: reindeer pastoralism. Reindeer have been important animals to the Saami speakers throughout their history in Scandinavia. As far as it is known, the South Saami were not domestic animal husbandry practitioners later in history; they practiced large-scale reindeer husbandry. The question is why practitioners of domestic animal husbandry ended up as reindeer herders.

Even though it seems that several reindeer words were borrowed from the Scandinavians, it should be noted that there have been semantic shifts from the original PScand word to the SaaS word in the case of every single word referring to reindeer. One such word is krievvie. The original meaning of it has nothing to do with the SaaS meaning 'reindeer herd (that is herded by a reindeer shepherd)' as the word was used to refer to 'a small corral for cattle' in ON. In the light of the lexical and archaeological evidence of Southern Proto-Saami speakers as animal husbandry practitioners, it is probable that the word preserved its original meaning after it was borrowed into Southern Proto-Saami. Only once the transition to reindeer pastoralism had taken place in the Viking Age (Aronsson 1991: 102; Hansen \& Olsen 2006: 99-100; Storli 1993: 3, 20; see below), and the meaning of 'cattle corral' was no longer needed, did the semantics of the word develop into the current meaning. The same applies to other reindeer words originating from this vocabulary.

It is certainly possible that only some of the Southern Proto-Saami speakers adopted domestic animal husbandry and the others continued as hunter-gatherers. Fossum (2006: 143) states that animal husbandry was connected to the Saami (speakers) who were involved with the iron production network. Reindeer pastoralism perhaps emerged after the most intensive iron manufacture phase was over and iron-related trade had decreased. Perhaps the (Southern Proto-)Saami speakers needed to find new ways of livelihood that profited them better both in trade with neighbouring groups and in providing food and other commodities to their own 
society. Reindeer pastoralism and hunting fur animals was the answer to that need (e.g. Aronsson 1991: 113; Hansen \& Olsen 2006: 99). The transition from livestock to reindeer pastoralism was gradual, as bones of livestock have been found from as late as the Middle Ages (Sundström 1989a: 159). Zachrisson (1997: 227) sees a pattern in graves that indicates a change from agrarian grave types to hunter-gatherer grave types in the upper parts of the river Ångermanälven during the Viking Age. The site is outside of the geographical area of this research but close to it. This pattern might be proof of (Southern Proto-)Saami speakers' gradual change from domestic animal herding to reindeer pastoralism and hunting. It is also possible that some of those (Southern Proto-)Saami speakers who practiced animal husbandry gradually assimilated into the Scandinavian speakers.

\subsection{Southern Proto-Saami contacts with Paleo-European of central Scandinavia}

The oldest hunting ground graves of Smalnäset and Krankmårtenhögen show unburnt elk and reindeer antlers and cranial parts deposited on the graves. This has no doubt been a religious or ritual affair, but it also reveals the importance of these animals as livelihood (e.g. Stedingk \& Baudou 2006: 187; Fossum 2006: 141). Recent datings from the antlers and cranial parts of Krankmårtenhögen suggest that the antlers and cranial parts are younger than many of the graves. It seems that the antlers were deposited on the graves up until the 500 S CE, during the 300 years after the burying had ceased. (Olofsson 2010: 100; Welinder 2008: 36, 60.)

There are no antlers and cranial parts found on any other hunting ground graves, with one uncertain exception (Halvfariudden). After the depositions cease in Krankmårtenhögen and Smalnäset, there is a gap of at least 200 years without antler depositions. They appear again in the archaeological material of the research area at the end of Merovingian Period and during the Viking Age - now as offers on sacrificial sites (Zachrisson 2009: 142). These sites have long been considered an important feature of a culture connected to the Saami (speakers).

The correlation between reindeer antlers and cranial parts found at the early cemeteries and the PScand loanword aevsie is quite striking. One would be tempted to connect the word with the antlers found on graves in Smalnäset and Krankmårtenhögen. However, the dating of the graves to Pre-Roman Iron Age (500-1 BCE) is a little too early for PScand or even 
NwG loanwords in Southern Proto-Saami. The predecessor of the modern South Saami language did not arrive in Scandinavia until after the beginning of the Common Era; maybe already as early as 100-200 CE but in 400/500 CE at the latest (see also Aikio 2006: 43; 2012: 77; J. Häkkinen 2010b: 59). Therefore, in theory and according to their dating, the depositions of antlers and cranial parts could have been made by Southern ProtoSaami speakers, but I would rather see a continuity from the grave-makers in the depositions. Even Stedingk and Baudou (2006: 186-187; see also Fossum 2006: 90) agree that in Krankmårtenhögen and Smalnäset a continuation from earlier hunter-gatherer cultures of the area is visible.

Who, then, were the grave-makers and what is their role in the South Saami prehistory? I propose that the graves were made by a Paleo-European speaking people who dwelled in the area before the Southern ProtoSaami and the Proto-Scandinavian speakers. Aikio $(2004,26)$ notes that the substrate influence has been partly contemporaneous with PScand loanwords in Saami. Paleo-European languages on Finnish soil have been studied (e.g. Aikio 2004; 2012; Saarikivi 2004), but no studies have yet been conducted about extinct languages in central and northern parts of Scandinavia as far as I am informed (however, see the map in Aikio 2012, 66 and Parpola 2017). Archaeologists have been reluctant to accept the presence of a third group in southern Norrland and Dalarna as a valid option: Stedingk and Baudou (2006) do not even consider the idea, and Zachrisson (2011: 198) seems to be against such an interpretation. However, Carpelan (2004: 82) has suggested that this hypothesis should be explored, and Olofsson (2010: 111) mentions it briefly.

When the Southern Proto-Saami language arrived in Scandinavia, it came in contact with the Paleo-European language. Very recently, Parpola (2017: 260) has proposed that a West-Uralic language form ${ }^{19}$ arrived in the area of Lake Mälaren along with Akozino-Mälar axes. Stedingk \& Baudou (2006: 187) and Fossum (2006: 140) note that the cemeteries of Krankmårtenhögen and Smalnäset are strongly influenced by the Mälaren area. It is possible that there is a connection between the Paleo-European language that would have been spoken in southern Norrland and the West-Uralic language spoken in Mälardalen. What kind of connection whether the Paleo-European speakers of southern Norrland were not, in fact, Paleo-Europeans at all but West-Uralic speakers - cannot be defined yet, and therefore I have decided to refer to the makers of the cemeteries of Krankmårtenhögen and Smalnäset as Paleo-European speakers. ${ }^{20}$ 
The contacts between the Southern Proto-Saami and Paleo-European languages became intensive, and the Southern Proto-Saami speakers adopted features from the Paleo-European culture. The hunting ground grave custom changes around $200 \mathrm{CE}$. I see this change as the immigration of Proto-Saami language (and speakers) into the area. ${ }^{21}$ The contacts between the Southern Proto-Saami and Paleo-European speakers also changed the Paleo-European culture, and the depositions on old cemeteries might be connected to this change and the need to remember one's ancestors. (For another recent interpretation of the depositions, see Olofsson 2010).

The Paleo-European speakers gradually adopted the Southern ProtoSaami language and these two groups assimilated into one. In this light, it is sufficient to state that the makers of the Krankmårtenhögen and Smalnäset cemeteries should be viewed as the ancestors of the South Saami, but they did not speak any form of a Saami language before the language shift. Therefore, it is questionable whether the grave-makers (and the cemeteries) can be called Saami, as has often been done in research.

The term pre-Saami (Norwegian førsamisk) proposed by Gjerde (2016: 235) could be, in theory, used to refer to the culture of the Paleo-Europeanspeaking people from a perspective that stresses their ancestral relationship to the Southern Proto-Saami and modern South Saami speakers. From a linguistic perspective the term in this meaning is, however, problematic, as Pre-Saami (or Pre-Proto-Saami) refers to the language form from which Proto-Saami developed. The language of those buried in Krankmårtenhögen and Smalnäset may have indeed affected Southern Proto-Saami, but it cannot be considered a Pre-Saami language form because its effect on Southern Proto-Saami would have been only substrate-like in nature.

Gjerde (2016: 224, 228), and other archaeologists who have proposed the heterogeneity of the hunting ground graves (see Gjerde 2016: 203 and the references there), do have a point: the lake and mountain graves of central Scandinavia have been in use for 1500 years, and it is a given that ethnic, cultural and language identities would change over such a long period: contacts with neighbouring people, environmental circumstances, diseases, technological developments and many other factors lead to change. From the linguistic perspective, however, the hunting ground graves could be Southern Proto-Saami from around 200 CE onwards. The influence from Paleo-European-speaking culture can still be seen, and the Proto-Scandinavian speakers influenced the grave customs for a long time after the Early Iron Age. 
The reindeer antlers on later sacrificial sites were the result of development of the (Southern Proto-)Saami culture into reindeer pastoralism, which was perhaps affected by ever more intensive contacts with the Scandinavians: when the reindeer pastoralism grew into a more profitable livelihood than domestic animal husbandry, it also affected the religious life. The word aevsie 'antlers and cranial parts of reindeer or elk' was perhaps borrowed from PScand with the orginal meaning of 'skull' and contracted to its current meaning only when the antlers became important religious objects around the emergence of the sacrificial sites. Therefore, even though the correlation between the word aevsie and the antlers in Krankmårtenhögen and Smalnäset is quite convergent, I do not see that there could be a connection between the word and the phenomenon.

The Viking Age in general is a period in history when the amount of sacred and profane remains increases in number. Fossum sees the phenomenon as a strengthening of ethnic identity of the Saami caused by the intensified contacts with other groups in the area. (Fossum 2006, 175.) To me it seems that the Viking Age is the first time the Saami-speaking society develops into the culture and ethnicity we have glimpses of in written sources and perhaps even oral folklore.

\subsection{Iron manufacture}

The discussion above has speculated on the involvement of the Southern Proto-Saami speakers in iron manufacture. There is no correlating evidence of iron manufacture in the two datasets used for this research, however. The archaeological material is visible, but no words referring to iron manufacture are found. Therefore, it is difficult to comment on the involvement of the Southern Proto-Saami speakers in the activity in the light of this research.

Nevertheless, I agree with Fossum (2006: 143) that the domestic animal husbandry among the Southern Proto-Saami speakers was connected to the iron manufacturing in Jämtland, Härjedalen and Dalarna - early datings of iron manufacture sites indicate this. According to the earlier Proto-Germanic loanword ruevtie 'iron', the Proto-Saami speakers were familiar with iron long before their contacts with NwG and PScand. It should be considered that the Scandinavians may have first learned of the rich iron ore sources of the inland regions from the Southern Proto-Saami speakers. It is probable that the iron manufacturers among the Southern 
Proto-Saami speakers were included in the iron production network as active operators, not passive workers as some have suggested (about the hypotheses on iron production, see e.g. Magnusson 1986; Ramqvist 2005a: 2005b, 16-17, 27 fig. 19). It is also possible that the Paleo-European people were the first ones involved in iron manufacture in the area as there is at least one iron manufacture site potentially dated to the Pre-Roman Iron Age (Josvedsviken 104195 BCE-207 CE; Magnusson 1986: 68, 149). However, this is a highly speculative hypothesis, and further research is needed to examine it.

\section{Conclusions}

The combination of archaeological and lexical research offers new advantages for the study of prehistory. It can verify hypotheses about phenomena and reveal completely new insights into the manner of contacts between different language groups and cultural and economical phenomena among a group of people. It could even reveal (a) language(s) spoken within an archaeological culture. In the future, the theoretical model should be tested with other material to see what kinds of further adjustments are needed.

My research shows that there is a plausible chance that the predecessor of the South Saami language immigrated to inland Scandinavia already during the Early Iron Age and had its contacts with PScand there. In fact, I suggest that the immigration took place already around $200 \mathrm{CE}$, that is, a few hundred years earlier than suggested by other linguists.

The presence of domestic animals among the Southern Proto-Saamispeaking culture of the Roman Iron Age and Migration Period has been studied from multidisciplinary perspectives which should be further debated among archaeologists and linguists. Related to this, it would be interesting to conduct palaeoecological research in the hunting ground areas of Jämtland, Härjedalen and Dalarna to see if it can provide more knowledge about cultivation in the area during the Early Iron Age.

Much could still be done with the data presented here as well: It would give an even more holistic picture of the past to examine the etymology of words referring to the archaeological find groups that lack correlating lexical finds. Another interesting perspective would be to examine the PScand loanwords in another Saami language and the archaeological remains of the area where the Saami language in question has been (and is) spoken. The differences and similarities in the results would provide more 
knowledge about the nature of language and cultural contacts of different Saami and Scandinavian speakers during the Early Iron Age.

Finally, further and thorough research is needed to examine the presence of a Paleo-European language in central and northern parts of Sweden and Norway during the Early Iron Age. Genetics combined with archaeology and linguistics might be of great interest to the language and cultural contacts that took place in the research area during the Iron Age. Ancient DNA samples from the osteological material of the later hunting ground graves with unburnt bones might bring another new perspective on the matters discussed here.

\author{
Minerva Piha \\ University of Turku \\ Department of Finnish and \\ Finno-Ugric Languages \\ FI-20014 Turun yliopisto
}




\section{Minerva Piha}

\section{Notes}

1 I am obliged to Jaakko Häkkinen, Inga Nieminen, Ulla Moilanen, Jasse Tiilikkala, Johan Schalin, Jussi Ylikoski and two anonymous referees for commenting on earlier versions of this article.

2 I have not included Saami archaeological material from Central Norway in my research because I have based my research on the hypothesis that the predecessor of the South Saami language first immigrated into Scandinavia around the Gulf of Bothnia, along the coast or by crossing over the southern part of the Gulf of Bothnia or over Kvarken. (I will examine these different routes in a later study.) This means that the language would have first arrived in the areas in Sweden.

3 I will discuss the research history of combining archaeological and linguistic studies elsewhere later.

4 In this article, I mark lexical finds in cursive. The concepts behind the words are in regular font. E.g. knife refers to the lexical find and knife refers to the concept of a knife.

5 Recently, a new identification method for separating the bones of sheep and goat in the archaeological material has also been introduced (see Salvagno \& Abarella 2017).

6 The list of references for every word in the material can be found in Appendix 2.

7 It should be noted that during the Early Iron Age there was no reindeer husbandry, not even reindeer pastoralism among the Southern Proto-Saami speakers. They might have kept a few tame reindeer to carry burdens or to lure wild reindeer into a trap (Hansen \& Olsen 2006, 198-209). I have decided to call the semantic category "reindeer and reindeer husbandry" because the categorization of words has been made according the modern meanings of words. The modern meanings are undoubtedly connected to reindeer husbandry.

8 The word for wool, ålloe, alla, is a Late PScand loanword (Heikkilä 2014: 119, $119 f$ 106), and is therefore excluded from my research data.

9 At the same time as the words referring to iron, a word for flint was most likely also borrowed. I have not included the word (dytnije 'flint; flintstone used as firesteel') in my analysis as the PScand form has not been reconstructed, although it has been suggested that the word is a loan from PScand. Flint may not have been a commonly used stone type before the contacts with PScand speaking people: (Southern) ProtoSaami might have been spoken earlier in areas with no flint. Additionally, as my anonymous referee has kindly pointed out, the word likely relates to firesteels that became widespread in Scandinavia during the Roman Iron Age.

10 In addition to these sites, there is one more cemetery, Södra Rullbonäset in the parish of Mora, which has 30 graves. Six of these were excavated in 1867 and 1920, but no reports of the excavations have survived. According to Serning (1966a: 163-165), the grave goods and osteological material were scarce. Only one fibula-shaped buckle was found, and this dates the cemetery to $200-550 \mathrm{CE}$. The cemetery is not among my research data.

11 In Saami linguistics, this term is used of a language form that has not undergone certain sound changes characteristic of Saami languages. For further discussion, see chapter 6.3.

12 It should be noted that there are iron manufacturing sites elsewhere in Sweden dating all the way back to the Pre-Roman Iron Age (500-1 BCE), but clear evidence 
from the area of Jämtland and Dalarna is missing (Magnusson 1986: 219-221) with the exception of one site (Tomte 1:2, Josvedsviken).

13 The archaeological report or any other detailed reference for RA ̈ 7 Övre Grundsjön, Härjedalen is missing so the information about the site is vague and therefore it is not listed in Table 5 .

14 The reference literature for my material is listed in Appendix 3.

15 Even if the artefacts found in graves were not everyday items, something similar were probably used in everyday life, and therefore I hold it plausible to discuss livelihood and everyday life based on grave finds.

16 Pollen analyses have been carried out using samples from nearby areas, and one of the samples can be dated to the Roman Iron Age. It has given proof of forest grazing and animal husbandry. (Stedingk \& Baudou 2006.) The sample site is, however, located in Ångermanland and is not further discussed here.

17 According to Heikkilä (2014: 240 footnote 200) the SaaS word hierkie 'horse' is a loanword from Finnish härkä 'ox' borrowed around the same time as the PScand words.

18 Sammallahti (1998: 227) presents the PScand loan etymology as uncertain. He holds the Finno-Saamic etymology SaaN áibmu (SaaS aajmoe) $\leftarrow$ FS *ajmo (cf. Finnish aimo 'a whole, quite a') as more certain. However, phonetically and semantically, the PScand etymology is just as likely. Lately, it has been argued that there is no common genetic Finno-Saamic protolanguage (e.g. Saarikivi \& Grünthal 2005: 124; Aikio 2012: 67-70).

19 Parpola (2017: 260) speaks of a Finno-Saamic proto-language, but it is not certain that there has been a common genetic proto-language for Finnish and Saami (e.g. Saarikivi \& Grünthal 2005: 124; Aikio 2012: 67-70). Aikio (2012: 70) notes that Finno-Saamic is, however, a valid areal grouping.

20 I will examine this hypothesis elsewhere later.

21 Zachrisson (1992) has studied the question of whether grave customs can be taken over by one ethnic group from another and reached the conclusion that it is possible. She uses the hypothesis to prove that the cemeteries of Krankmårtenhögen and Smalnäset in Härjedalen are of Saami origin even though they were influenced by Germanic grave customs. As I have argued, those cemeteries should be viewed as Paleo-European and as having been influenced by customs from perhaps a WestUralic speaking people from Mälardalen, and the later hunting ground graves can be seen as belonging to Saami speakers influenced by the Paleo-European grave customs of Krankmårtenhögen and Smalnäset. Germanic grave customs have also influenced later Saami-related hunting ground graves, e.g. at Långön, Ångermanland (Zachrisson 1992: 111).

22 The category includes words referring to humans in their different ages as well as their positions or relations in a society.

23 The two words in the category are somewhat haphazard as they do not have much in common. Aevhkie can, however, be interpreted as a condition and gaavnedh as a change (rather than an action process). As there is not much point in having many categories with only one word, especially if the word is not vastly important from the perspective of the combination of archaeology and linguistics, I have decided to classify these two together. 


\section{Minerva Piha}

24 All words that are related to time and space and do not fit into other categories are placed in this category.

25 This category includes all words referring to reindeer, regardless of whether they refer to reindeer as wild or tame animals.

26 This category is made up of all the words that do not fit into any other categories.

27 I am obliged to Anu Soikkeli-Jalonen for suggesting this hypothesis.

\section{Abbreviations}

$\begin{array}{ll}\text { dial. } & \text { dialect } \\ \text { E } & \text { English } \\ \text { I } & \text { Icelandic } \\ \text { N } & \text { Norwegian } \\ \text { NwG } & \text { Northwest Germanic } \\ \text { ON } & \text { Old Norse } \\ \text { PG } & \text { Proto-Germanic } \\ \text { PS } & \text { Proto-Saami } \\ \text { PScand } & \text { Proto-Scandinavian } \\ \text { SaaI } & \text { Inari Saami } \\ \text { SaaK } & \text { Kildin Saami } \\ \text { SaaL } & \text { Lule Saami } \\ \text { SaaN } & \text { North Saami } \\ \text { SaaP } & \text { Pite Saami } \\ \text { SaaS } & \text { South Saami } \\ \text { SaaSk } & \text { Skolt Saami } \\ \text { SaaT } & \text { Ter Saami } \\ \text { SaaU } & \text { Ume Saami } \\ \text { Sw } & \text { Swedish }\end{array}$

\section{References}

Aikio, Ante 2004: An essay on substrate studies and the origin of Saami. - Irma Hyvärinen, Petri Kallio \& Jarmo Korhonen (eds), Etymologie, Entlehnungen und Entlwicklungen. Festschrift für Jorma Koivulehto zum 7o. Geburtstag. Helsinki: Mémoires de la Société Néophilologique de Helsinki LXIII. 5-34.

Aikio, Ante 2006: On Germanic-Saami Contacts and Saami Prehistory. JSFOu 91. 9-55.

Aikio, Ante 2009: The Saami loanwords in Finnish and Karelian. Oulu: University of Oulu.

Aikio, Ante 2012: An essay on Saami ethnolinguistic prehistory. - Riho Grünthal \& Petri Kallio (eds), A Linguistic Map of a Prehistoric Northern Europe. MSFOu 266. 63-117.

ÁLGU. Kotimaisten kielten keskus. <http://kaino.kotus.fi/algu/index.php?t=haku\&l=1> 9 May 2018. 


\section{Combining Proto-Scandinavian loanword strata in South Saami ...}

Ambrosiani, Björn, Elisabeth Iregren \& Pirjo Lahtiperä 1984: Gravfält i fångstmarken. Rapport 1984:6. Stockholm: Riksantikvarieämbetet och Statens historiska museet.

Anthony, David W 2007: The Horse, The Wheel, and Language. How Bronze-Age Riders from the Eurasian Steppes Shaped the Modern World. Princeton \& Oxford: Princeton University Press.

Aronsson, KJell-Åke 1991: Forest reindeer herding A.D. 1-180o. An archaeological and palaeoecological study in northern Sweden. Archaeology and Enviroment 10. Umeå: University of Umeå, Department of Archaeology.

BAUdou, EvERT 1987: Samer och germaner i det förhistoriska Norrland. En kritisk översikt över tio års forskning. Bebyggelsehistorisk tidsskrift 14. 9-23.

Bergsland, Knut 1964: Suomen soihtu lapin valossa. Virittäjä 68. 144-147.

Bergsland, KnUt 1988: Eteläsaamen krievvie 'porolauma'. Virittäjä 92. 161-163.

Bergsland, KNUt 1992: Language Contacts between Southern Sami and Scandinavian. - Ernst Håkon Jahr (ed.), Language Contact: Theoretical and Empirical Studies. Berlin: Monton de Gruyter. 5-15.

Bergsland, Knut \& Lajla Mattson Magga 2007 [1993]: Åarjelsaemien-daaroen baakoegärja. Sydsamisk-norsk ordbok. Ikkaldas: Idut.

Bjorvand, Harald \& Fredrik Otto Lindeman 2007. Våre arveord. Etymologisk ordbok. Revidert og utvidet utgave. Instituttet for sammenlignende kulturforskning, Serie B: Skrifter. Oslo: Novus forlag.

Campbell, Lyle 1998: Historical Linguistics. An Introduction. Edinburgh: Edinburgh University Press.

Carpelan, Christian 1999: Käännekohtia Suomen esihistoriassa aikavälillä 5100...1000 eKr. - Paul Fogelberg (ed.), Pohjan poluilla. Suomalaisten juuret nykytutkimuksen mukaan. Bidrag till kännedom av Finlands natur och folk 153. Helsinki: Societas Scientiarum Fennica. 249-280.

Carpelan, Christian 2004: Etnicitet, identitet, ursprung? Exemplet samerna. - Herva, Vesa-Pekka (ed.), People, material culture and environment in the north. Proceedings of the 22nd Nordic Archaeological Conference, University of Oulu, 18-23 August 2004. Studia humaniora Ouluensia 1. Oulu: Faculty of Humanities, University of Oulu. $75-82$.

Carpelan, Christian \& Asko Parpola 2001: Emergence, contacts and dispersal of Proto-Indo-European, Proto-Uralic and Proto-Aryan in archaeological perspective. - Christian Carpelan, Asko Parpola \& Petteri Koskikallio (eds). Early Contacts between Uralic and Indo-European: Linguistic and Archaeological Considerations. $\mathrm{Pa}$ pers presented at an international symposium held at the Tvärminne Research Station of the University of Helsinki 8-10 January, 1999. MSFOu 242. 55-150.

Collinder, BJöRn 1932: Wortgeschichtliches aus dem bereich der germanicsh-finnischen und germanisch-Lappischen Lehnbeziehungen. Acta Philologica Scandinavica 7. Copenhagen: Danske sprog- og litteraturselskab. 193-225.

Collinder, BJöRn 1964: Ordbok til Sveriges lapska ortnamn. Uppsala: Sveriges ortnamn. Kungl. ortnamnskommissionen.

DALIN, STEFAN 1995: Till vem hör insjögraven? En rumslig analys av insjögravarna i Jämtland/Härjedalen. CD-uppsats i arkeologi. Umeå universitet.

De Caprona, Yann 2013: Norsk etymologisk ordbok. Tematisk ordnet. Oslo: Kagge. 


\section{Minerva Piha}

Durkin, Philip 2009. The Oxford Guide to Etymology. Oxford: Oxford University Press.

Fossum, Birgitta 2006: Förfädernas land. En arkeologisk studie av rituella lämningar i Sápmi 300 f.Kr-16oo e.Kr. Studia archaeologica universitatis Umensis 22. Umeå: Umeå universitet.

Gejvall, N.-G. 1966: Osteologisk analys av brandgravsben från Ore-Oresjön-Vindförberg, Rättvik-Hästudden samt Transtrand-N. och S. Bredsundsnäset och Hästnäset. Bilaga 1. - Inga Serning: Dalarnas Järnålder. Stockholm: Kungliga vitterhets historie och antikvitetsakademien. 253-254.

GJerde, Hege 2016: Sørsamisk eller førsamisk? Arkeologi og sørsamisk forhistorie i SørNorge - en kildekritisk analyse. Oslo: Universitetet i Oslo.

GustafsSON, ERIKA 1995: Vindförbergs udde. Kring insjögravsproblematiken. Magisteruppsats i arkeologi. Stockholms universitet.

HÄKKINEN, JАAKKO 2007: Kantauralin ajoitus ja paikannus: perustelut puntarissa. JSFOu 92. 9-56.

Ḧ̈KKINEN, JААКко 2010a: Jatkuvuusperustelut ja saamelaisen kielen leviäminen. Muinaistutkija 1/2010. 19-36.

НÄKKINEN, JАAKKO 2O10b: Jatkuvuusperustelut ja saamelaisen kielen leviäminen (osa 2). - Muinaistutkija 2/2010. 51-64.

HäKKInen, KaISA 1997: Mistä sanat tulevat. Suomalaista etymologiaa. Tietolipas 117. Helsinki: Suomalaisen Kirjallisuuden Seura.

HÄKKINEN, KAISA 1999: Esisuomalainen pyyntikultuuri ja maanviljely sanastohistorian kannalta. - Paul Fogelberg (ed.), Pohjan poluilla. Suomalaisten juuret nykytutkimuksen mukaan. Bidrag till kännedom av Finlands natur och folk 153. Helsinki: Societas Scientiarum Fennica. 158-173.

HäKKInEN, KaISA 2001: Prehistoric Finno-Ugric culture in the light of historical lexicology. - Christian Carpelan, Asko Parpola \& Petteri Koskikallio (eds), Early Contacts between Uralic and Indo-European: Linguistic and Archaeological Considerations. $\mathrm{Pa}$ pers presented at an international symposium held at the Tvärminne Research Station of the University of Helsinki 8-10 January, 1999. MSFOu 242. 169-186.

Hansen, Lars Ivar \& BJørnar Olsen 2006: Samernas historia fram till 1750. Stockholm: Liber.

Halinen, Petri 1996. Pyyntikuoppien ajoittamisesta. - Helena Ranta (ed.), Kentältä poimittua 3. Museoviraston arkeologian osaston julkaisuja N:o 3. Helsinki: Museovirasto. 59-63.

Hasselbrink, GustaV 1981: Südlappisches Wörterbuch. Schriften des Instituts für Dialektforschung und Volkskunde in Uppsala. Ser C:4. Uppsala: AB Lundequistska Bokhandeln.

HeıккIl Ä, Mıкко 2011: Huomioita kantasaamen ajoittamisesta ja paikantamisesta sekä germaanisia etymologioita saamelais-suomalaisille sanoille. - Virittäjä 1/2011. 68-82.

НегккILё, Мıкко 2014: Bidrag till Fennoskandinaviens språkiga förhistoria i tid och rum. Helsinki: Helsingfors universitet.

Hemmendorff, Ove 1984: Sammanfattande beskrivning av gravarna vid Grundsjöarna. Jämtlands läns museum 56. Östersund: Jämtlands läns museum.

HemmendorfF, Ove 1989a: Inledning. - Ove Hemmendorff (ed.), Arkeologi i fjäll, skog och bygd 1. Stenålder - tidig järnålder. Fornvårdaren 23. Östersund: Jämtlands läns museum. 7-27. 


\section{Combining Proto-Scandinavian loanword strata in South Saami ...}

Hill, J. N. \& R. K. Evans 1972: A model for classification and typology. - David L. Clarke (ed.), Models in Archaeology. London: Methuen \& Co Ltd. 231-273.

Hodder, IAN 1982. Symbols in action. Ethnoarchaeological studies of material culture. Cambridge: Cambridge University Press.

Hodder, IAN \& SCOTt Hutson 2003: Reading the past. Current approaches to interpretation in archaeology. 3. edition. New York: Cambridge University Press.

Holm, Jenny \& KajSA WiLlemarK 1988: Rapport över arkeologisk undersökningar av skadade anläggningar på fornl $\mathrm{nr} 77$, ett gravfält, Ljungdalen 1:4, S torsjö sn, Härjedalen. Östersund: Jämtlands läns museum.

Hvarfner, Harald \& Lars Åke Kvarning 1958: Rapport över kulturhistoriska undersökningar vid sjön Lossen I Ljusnans källområden, Tännas socken, Härjedalen 1956-1958. Del II Gravfältet på Smalnäset. Stockholm: Riksantikvarieämbetet.

Hyenstrand, Åke 1972: Production of Iron in Outlying Districts and the Problem of Järnbäraland. A cartographic study. Early Medieval Studies 4. Antikvariskt arkiv 46. Stockholm: Riksantikvarieämbetet.

Hyenstrand, Åke 1974: Järn och bebyggelse. Dalarnas hembygdsbok 1974. Falun: Dalarnas fornminnes och hembygdsförbund, Dalarnas museum.

Hyenstrand, ÅKe 1987: Lima och Transtrand. Ur två socknars historia. Malung: Fehrms bokhandeln.

JENSEN, RonNiE 1989: Hällbilder och fångstboplatser. - Ove Hemmendorff (ed.), Arkeologi i fjäll, skog och bygd 1. Stenålder - tidig järnålder. Fornvårdaren 23. Östersund: Jämtlands läns museum. 57-82.

Johansson, Hanna 2016: Gravar i Fångstmarken. En osteologisk analys av 10 gravar från Vindförbergs udde i norra Dalarna. Kandidatuppsats. Institutionen fr arkeologi och antikens kultur, Uppsala universitet.

JSFOU = Journal de la Societe Finno-Ougrienne. Helsinki: Suomalais-Ugrilainen Seura.

Kallio, Petri 2006: Suomen kantakielen absoluuttista kronologiaa. Virittäjä 1/2006. 2-25.

Koivulehto, Jorma 1971: Germanisch-finnische Lehnbeziehungen I. Neuphilologische Mitteilungen 72. 577-607.

Koivulehto, Jorma 1976: Vanhimmista germaanisista lainakosketuksista ja niiden ikäämisestä. Virittäjä 80. 33-47, 247-290.

KoIVulehto, JoRma 1979: Lainoja ja lainakerrostumia. Virittäjä 83. 267-296. [VV 32-66.]

Koivulehto, Jorma 1981: Die Datierung der ältesten germanischen Lehnwörter im Finnischen. - Osmo Ikola (ed.), Congressus Quintus Internationalis Fenno-Ugristarum Turku 20. -27. VII. 1980. 7: Dissertationes sectionum: Lexicologia et onomastica, alia linguistica et litteraria. Turku. 73-78.

Koivulehto, Jorma 1984: Itämerensuomalais-germaaniset kosketukset. - Sven-Erik Åström (ed.), Suomen väestön esihistorialliset juuret. Tvärminnen symposiumi 1719.1.1980. Bidrag till kännedom av Finlands natur och folk 131. Helsinki: Societas Scientiarum Fennica. 191-204. [VV 113-127.]

Koivulehto, Jorma 1987: Zu den frühen Kontakten zwischen Indogermanisch und Finnisch-Ugrisch. - Ewald Lang \& Gert Sauer (eds), Parallelismus und Etymologie, Studien zu Ehren von Wolfgang Steinitz anläßlich seines 8o. Geburtstags am 28. Februar 1985. Linguistische Studien Reihe A 161/II. Berlin: Akademie der Wissenschaften der DDR, Zentralinstitut für Sprachwissenschaft. 195-218. 
KoIvulehto, Jorma 1988: Lapin ja itämerensuomen suhteesta ieur. -Tr-yhtymän korvautuminen lainoissa. Virittäjä 92. 26-51.

Koivulehto, Jorma 1989: Etymologioinnin periaatteita: suomen keto, saamen giedde. Sananjalka 31. 39-52. [VV 154-167.]

KoIVulehto, Jorma 1990: Sananselityksiä: Karjanhoitoa. Kieliposti 4/1990. 36-37.

Koivulento, Jorma 1991: Uralische Evidenz für die Laryngaltheorie. Sitzungsberichte der Österreichischen Akademie der Wissenschaften, Philosophisch-historische Klasse 566 / Veröffentlichungen der Kommission für Linguistik unde Kommunikationsforschung 24. Wien: Verlag der Österreichischen Akademie der Wissenschaften.

Koivulehto, Jorma 1992a: Germanisch-lappische Lehnbeziehungen. - Lásló Honti, Sirkka-Liisa Hahmo, Tette Hofstra, Jastrzębska \& Osmo Nikkilä (eds), Finnischugrische Sprachen zwischen dem germanischen und dem slavischen Sprachraum. Vorträge des Symposiums aus Anlaß des 25-jährigen Bestehens der Finnougristik an der Rijksuniversiteit Groningen 13.-15. November 1991. Amsterdam: Rodopi. 85-95.

Koivulehto, Jorma 1992b: Direkte Kontakte des Lappischen mit dem Baltischen. Deréky von Pál, Timothy Riese, Marianne Bakró-Nagy \& Péter Hajdú (eds), Festschrift für Károly Rédei zum 6o. Geburtstag. Studia Uralica 6. Wien: Harrassowitz. 299-304. [VV 173-178.]

Koivulehto, Jorma 1993a: Zur Etymologie von fi. susi, tosi - und kesi: eine Entgegnung. Linguistica Uralica 29. 21-37.

KoIvulehto, JoRma 1993b: Alte Lehnwörter meteorologischen Inhalts: lappisch âr've 'Regen'. Nyelvtudományi Közlemények 91 (1990). 127-131. [VV 168-172.]

KoIvulehto, Jorma 1995: Ala-Satakunnan Kainu ja pohjoisen Kainuu. - Kielen ja kulttuurin Satakunta. Juhlakirja Aimo Hakasen 6o-vuotispäiväksi 1.11.1995. Publications of the Department of Finnish and General Linguistics of the University of Turku 51. Turku: Department of Finnish and General Linguistics of the University of Turku. 71-104.

Koivulehto, Jorma 1997a: Were the Baltic Finns "clubmen"? On the etymology of some ancient ethnonyms. - Ritva Liisa Pitkänen \& Kaija Mallat (eds), You name it. Perspectives on onomastic research. Studia Fennica Linguistica 7. Helsinki: Suomalaisen Kirjallisuuden Seura. 151-169.

Koivulehto, Jorma 1997b: Die alten Sprach- und Kulturbeziehungen zwischen Germanen und Finnen. - Bendel von Burghardt, Clemens-Peter Haase \& Olli Salminen (eds), Deutsche Sprache und Kultur - Brücke und Scharnier im Nordosten Europas? Vorträge auf der Nordichen Konferenz 6.-9. September 1995 in Tampere/Finnland. Deutche Studien Tampere 2. Tampere: Universität Tampere. 77-94.

KoIvulehto, Jorma 1999a: Verba mutuata. Quae vestigia antiquissimi cum Germanis aliisque Indo-Europaeis contactus in linguis Fennicis reliquerint. MSFOu 237. Helsinki: Suomalais-Ugrilainen Seura.

Koivulehto, Jorma 1999b: Das Verhältnis des Ostseefinnischen und des Lappischen im Lichte der alten Lehnwörter: Die Substitution des fremden Wortausgangs ${ }^{*}-\mathrm{CVz}$ im Lappischen. - Pekka Lehtimäki (ed.), Sprachen in Finnland und Estland. Wiesbaden: Harrassowitz Verlag. 7-22.

KoIVUlehto, Jorma 1999c: Varhaiset indoeurooppalaiskontaktit: aika ja paikka lainasanojen valossa. - Paul Fogelberg (ed.), Pohjan poluilla. Suomalaisten juuret nykytutkimuksen mukaan. Bidrag till kännedom av Finlands natur och folk 153. Helsinki: Societas Scientiarum Fennica. 207-236. 
Koivulehto, Jorma 2001: Zum frühen iranischen und indoiranischen lexikalischen Einfluss auf das Finnisch-Ugrische. - Klaus Karttunen \& Petteri Koskikallio (eds), Vidyärnavavandanam. Essays in Honour of Asko Parpola. Studia Orientalia 94. Helsinki: the Finnish Oriental Society. 359-378. [VV 257-276.]

Koivulehto, Jorma 2002: Contact with non-Germanic languages II: relations to the east. - Oskar Bandle, Kurt Braunmüller, Ernst Håkan Jahr, Allan Kraker, Hans-Peter Naumann \& Ulf Teleman (eds), The Nordic languages. An international handbook of the history of the North Germanic languages. Vol. 1. S. 583-594. Berlin - New York: De Gruyter Mouton. 583-594.

KoIvulehto, Jorma 2003: Frühe Kontakte zwischen Uralisch und Indogermanisch im nordwestindogermanischen Raum. - Alfred Bammesberger \& Theo Venneman (eds), Languages in Prehistoric Europe. Heidelberg: Universitatsverlag Winter. 279-317.

KoIvulehto, JoRma 2006: Finnische Namen germanischer Herkunft für Weidenarten. - Ulrich Breuer \& Irma Hyvärinen (eds), Wörter - Verbindungen. Festschrift für Jarmo Korhonen zum 6o. Geburtstag. Frankfurt: Peter Lang GmbH, Internationaler Verlag der Wissenschaften. 423-430.

Koivulehto, Jorma 2008: Zwei alte skandinavische Lehnwörter im Saamischen. K. Dekker, A. A. MacDonald \& H. Niebaum (eds), Northern voices: essays on Old Germanic and related topics, offered to professor Tette Hofstra. Mediaevalia Groningana. New series; vol. 11. Leuven: Peeters. 321-326. [VV 390-395.]

KoIvulehto, Jorma 2009: Etymologisesti hämäriä -(is)tA-johdosverbejä, lainoja ja omapohjaisia. JSFOu 92. 79-102. [VV 409-432.]

Koivulehto, JoRma 2016: Verba Vagantur. Jorma Koivulehto in memoriam. - Sampsa Holopainen, Petri Kallio \& Janne Saarikivi (eds). MSFOu 274.

Korhonen, Мıкко 1981: Johdatus lapin kielen historiaan. Suomalaisen Kirjallisuuden Seuran Toimituksia 37o. Helsinki: Suomalaisen Kirjallisuuden Seura.

LAgerCRAntz, Eliel 1926: Wörterbuch des südlappischen nach der mundart von Wefsen. Skrifter Instituttet for sammenlignende Kulturforskning. Serie B 4. Oslo: H. Aschehoug.

Lagercrantz, Eliel 1939: Lappischer Wortscgatz I \& II. Lexica Societatis Fenno-Ugricae 6. Helsinki: Suomalais-Ugrilainen Seura.

LÄGLOS = Lexikon der älteren germanischen Lehnwörter in den ostseefinnischen Sprachen 1-3 (1991, 1996, 2012). A.D. Kylstra (ed). Amsterdam/Atlanta: Rodopi.

LARJE, RitA 1989: Analys av benmaterial från skogsgrav Raä 10:1, Nyhem sn, 1989-02o9. Östersund: Jämtlands läns museum.

Larsson, Gunilla 2007: Ship and Society. Maritime Ideology in Late Iron Age Sweden. Uppsala: Department of Archaeology and Ancient History, Uppsala University.

LEHTIRANTA, JUHANI 1989: Yhteissaamelainen sanasto. MSFOu 200.

Lipping, Magdalena 1981: Vindförberg. Fynd och fyndmiljö i bioarkeologisk belysning. Dalarnas museums serie av rapporter 10. Falun: Dalarnas museum.

MAGNusson, GERT 1986: Lågteknisk järnhantering i Jämtlands län. Jernkontorets Bergshistoriska Skriftserie N:r 22. Stockholm: Jernkontoret.

Mallory, J.P. 1989: In Search of the Indo-Europeans. Language, Archaeology and Myth. London: Thames and Hudson. 
Melander, Jan 1989: Fångstgropar i Jämtland. - Ove Hemmendorff (ed.), Arkeologi i fjäll, skog och bygd 1. Stenålder - tidig järnålder. Fornvårdaren 23. Östersund: Jämtlands läns museum. 115-127.

MSFOu = Mémoires de la Société Finno-Ougrienne. Helsinki: Suomalais-Ugrilainen Seura.

Myrstad, Ragnhild 1997: Bjørnegraver i Nord-Norge. Spor etter den samiske bjørnekulten. Stensilserie B nr. 46. Tromsø: Universitetet i Tromsø.

Nielsen, Niels Åge 1976: Dansk etymologisk ordbok. Ordenes historie. 3. reviderede udgave med et tilloeg. Copenhagen: Gyldendal.

Nilsen, Gørill 2016: Marine Mammal Train Oil Production Methods: Experimental Reconstructions of Norwegian Iron Age Slab-Lined Pits. Journal of Maritime Archaeology 11(2). 197-217.

NoRdic LANGUAGES = Nordic Languages. An international handbook of the history of the Nordic Languages. Volume I. Oskar Bandle (ed.). Berlin 2002.

Olofsson, Camilla 2010: Making New Antlers: Depositions of Animal Skulls and Antlers as a Message of Regeneration in South Sámi Grave Contexts. Norwegian Archaeological Review 43 (2). 97-114.

Olsen, BJøRnar 2003: Material Culture after Text: Re-Membering Things. Norwegian Archaeological Review 36 (2). 87-104.

Olsen, Bjørnar 2010: In Defence of Things. Archaeology and the Ontology of Objects. Lanham: AltaMira Press.

OsKARsSON, BJÖRN 1998: Rapport över arkeologisk undersökningar av RÄ̈ 154, stenåldersboplats samt järnåldersgrav vid Storsjön, Stosjö 17:5, Storsjö sn, Bergs kommun, Jämtlands län. Östersund: Jämtlands läns museum 481.

PARPola, AsKo 1999: Varhaisten indoeurooppalaiskontaktien ajoitus ja paikannus kielellisen ja arkeologisen aineiston perusteella. - Paul Fogelberg (ed.), Pohjan poluilla. Suomalaisten juuret nykytutkimuksen mukaan. Bidrag till Kännedom av Finlands natur och folk 153. Helsinki: Societas Scientiarum Fennica. 180-206.

PARpola, Asko 2017: Finnish vatsa Sanskrit vatsá and the formation of Indo-Iranian and Uralic languages. JSFOu 96. 245-286.

PentikäInen, Juha 1995: Saamelaiset - pohjoisen kansan mytologia. Suomalaisen Kirjallisuuden Seuran Toimituksia 596. Helsinki: Suomalaisen Kirjallisuuden Seura.

Pina, Minerva 2016: Kontaktien ja kulttuuri-ilmiöiden näkyminen saamen germaanisissa lainasanoissa - vertailukohtana arkeologinen aineisto. Master's thesis. University of Turku.

Piha, Minerva \& JaAKKo HäKKInen forthcoming.

Qvigstad, J. K. 1893: Nordische Lehnwörter in Lappischen. Christiania Videnskabs-Selskabs forhandlinger. Christiania: Christiania Videnskabs-Selskab.

RAmQvist, Per H. 2005a: Regional variation och samhälle i Norden under den äldre järnåldern. - Per H. Ramqvist. Några aktuella problemställningar inom nordlig arkelogi. Ett urval av artiklar an Per H. Ramqvist. Umeå: Umeå universitet. 25-48.

RAMQvist, Per H. 2005b: Förhistoria I Medelpad. Samhälleliga förandringar ca 7000 f $\mathrm{Kr}-1100$ e $\mathrm{Kr}$ - Per H. Ramqvist. Mittnorden under det första årtusendet e Kr. Ett urval av artiklar av Per H. Ramqvist. Umeå: Umeå universitet. 1-38.

RAMQvist, Per H. 2007: Fem Norrland. Om norrländska regioner och deras interaction. Arkeologi i norr 10. 153-180. 
Renfrew, Colin 1987: Archaeology and language. The Puzzle of Indo-European Origins. New York: Cambridge University Press.

SAARIKIVI, JANNE 2004: Is there Palaeo-European substratum interference in the western branches of Uralic? JSFOu 90. 187-214.

SAARIKIVI, JANNE 2011: Saamelaiskielet - nykypäivää ja historiaa. - Irja Seurujärvi-Kari, Petri Halinen \& Risto Pulkkinen (eds), Saamentutkimus tänään. Tietolipas 234. Helsinki: Suomalaisen Kirjallisuuden Seura. 77-119.

SAARIKIVI, JANNE \& RIHO GRÜNTHAL 2005: Itämerensuomalaisten kielten uralilainen tausta. - J. Vaattovaara, T. Suutari, H. Lappalainen, \& R. Grünthal (eds). Muuttuva muoto: kirjoituksia Tapani Lehtisen 6o-vuotispäivän kunniaksi. Kieli 16. Helsinki: Helsingin yliopiston suomen kielen laitos. 111-146.

SaArikivi, Janne \& Mika Lavento 2012: Linguistics and Archaeology. A Critical View of an Interdisciplinary Approach with Reference to the Prehistory of Northern Scandinavia. - Charlotte Damm \& Janne Saarikivi (eds), Networks, Interaction and Emerging Identities in Fennoscandia and Beyond. Papers from the conference held in Tromsø, Norway, October 13-16, 2009. MSFOU 265. 177-216.

Salvagno, Lenny \& Umberto Albarella 2017: A morphometric system to distinguish sheep and goat postcranial bones. - PLoS ONE 12(6). <https://doi.org/10.1371/ journal.pone.0178543>2 August 2017

Sammallahti, Pekka 1998: The Saami Languages. An Introduction. Kárášjohka: Davvi Girji.

Sammallahti, PekKa 1999: Saamen kielen ja saamelaisten alkuperästä. - Paul Fogelberg (ed.), Pohjan poluilla. Suomalaisten juuret nykytutkimuksen mukaan. Bidrag till Kännedom av Finlands natur och folk 153. Helsinki: Societas Scientiarum Fennica. 70-90.

Sammallahti, Pekka 2001: The Indo-European loanwords in Saami. - Christian Carpelan, Asko Parpola \& Petteri Koskikallio (eds), Early Contacts between Uralic and Indo-European: Linguistic and Archaeological Considerations. Papers presented at an international symposium held at the Tvärminne Research Station of the University of Helsinki 8-10 January, 1999. MSFOu 242. 397-416.

Sammallahti, Pekka 2012: Bottlenecks and Contacts in the Linguistic Prehistory of the Saami. - Charlotte Damm \& Janne Saarikivi (eds), Networks, Interaction and Emerging Identities in Fennoscandia and Beyond. MSFOu 265. 93-104.

SCHALIN, JoHAN 2016: Östskandinavisk utveckling av den urnordiska ai-diftongen och palatalt $r$ i ljuset av finska ljudsubstitutioner. - Daniel Andersson, Lars-Erik Edlund, Susanne Haugen \& Asbjørg Westum (eds), Studier i svensk språkhistoria 13. Historia och språkhistoria. Nordsvenska 25. Kungl. Skytteanska Samfundets Handlingar 76. Umeå: Institutionen för språkstudier, Umeå universitet \& Kungl. Skytteanska Samfundet. 241-262.

Schalin, Johan 2017: Scandinavian Front Umlaut Revisited and Revised. Arkiv för nordisk filologi 132. 5-73.

SERNING, INGA 1962: Järnåldersgravarna vid Horrmundsjön i Transtrands socken. - Björn Hallerdt (ed.), Från Dalarnas forntid och medeltid. Dalarnas Hembygdsbok 1962. Falun: Dalarnas Fornminnes och Hembygdsförbund. 31-86.

SERNING, INGA 1966a: Dalarnas järnålder. Stockholm: Kungliga vitterhets historie och antikvitetsakademien. 


\section{Minerva Piha}

SERNING, INGA 1966b: 5916/66. Antikvarisk-topografiska arkivet, grävrapport.

SERNING, INGA 1966c: 2437/66. Antikvarisk-topografiska arkivet, grävrapport.

SERNING, INGA 1967: 7161/67. Antikvarisk-topografiska arkivet, grävrapport.

Simonsen, Povl 1973: Jægar og nomader i Finnmark. Bonde - Veidemann. Bofast ikke bofast. Nordisk Forhistorie. Foredrag og diskusjoner fra XIII Nordiske Arkeologmøte i Tromsø 1970. Tromsø Museums Skrifter XIV. Tromsø: Tromsø Museum.

SkÖLD, TRYGgve 1954: Om uttalet av runan R och några nordiska låneord i lapskan. - Dag Strömbäck (ed.), Scandinavia et Fenno-Ugrica. Studier tillängnade Björn Collinder den 22 juli 1954. Stockholm: Almqvist \& Wiksell. 33-48.

SKöld, TrYggVe 1960: Einige germanische Lehnwörter im Lappischen und Finnischen. Uppsala Universitets Årsskrift 1960:2. Uppsala: Uppsala universitet.

Sköld, Tryggve 1961: Die Kriterien der urnordischen Lehnwörter im Lappischen. I Einleitende kapitel anlautender konsonantismus vokalismus der ersten silbe. Skrifter utgivna av institutionen för nordiska spark vid Uppsala Universitet 8. Uppsala: Uppsala universitet.

Sköld, Tryggve 1980: The earliest contacts between Lapps and Scandinavians. FennoUgrica Suecana 2. Uppsala: Fenno-ugriska institutionen, Uppsala universitet. 105116.

SKöld, TRYgGVe 1986: Ein nordisches Lehnwort im lappischen. - Károly Gerstner, Sirkka-Liisa Hahmo, Tette Hofstra, Jastrzębska \& Osmo Nikkilä (eds), Lyökämme käsi kätehen. Beträge zur Sprachkontaktforschung im Bereich des Finnougrischen und des Germanischen A.D. Kylstra zum 65. Geburtstag. Amsterdam: Rodopi. 131-150.

SSA 1-3 = Suomen sanojen alkuperä. Etymologinen sanakirja 1-3 1992, 1995, 2000. Helsinki: Suomalaisen Kirjallisuuden Seura, Kotimaisten kielten tutkimuskeskus.

Stedingk, Henrik von \& BAudou, Evert 2006: Capitalism in Central Norrland, Sweden during the Iron Age. Current Swedish Archaeology 14. 177-198.

STORLI, INGER 1986: A review of archaeological research on Sami prehistory. Acta Borealia 3 (1). 43-63.

Storli, INGER 1993: Sami Viking Age Pastoralism - or “The Fur Trade Paradigm' Reconsidered. Norwegian Archaeological Review 26 (1). 1-20.

Sundström, JAN 1984: Rapport över fornlämning nr 9, Ljungå 1:1, Hällesjö socken, Bräcke kommun, Jämtland. Delundersökning och återställning av stensättning. Jämtlands läns museum 189. Östersund: Jämtland läns museum.

SundströM, JAN 1989a: Järnåldersgravar i fångstlandet. - Ove Hemmendorff (ed.), Arkeologi i fjäll, skog och bygd 1. Stenålder - tidig järnålder. Fornvårdaren 23. Östersund: Jämtlands läns museum. 155-171.

SunDSTRÖM, JAN 1989b: Rapport över arkeologisk undersökning och återställning av en stensättning, Raä 10:1, Klevsand, Gindalen 2:11, Nyhem sn, Bräcke kn, Jämtland. Jämtlands läns museum 194. Östersund: Jämtland läns museum.

SUNDSTRÖM, JAN 1989c: Juvuln - 3000 år i fjällnära fångstland. - Ove Hemmendorff (ed.), Arkeologi i fjäll, skog och bygd 1. Stenålder - tidig järnålder. Fornvårdaren 23. Östersund: Jämtlands läns museum. 83-102.

SUNDSTRÖM, JAN 1994: Järnålder i Jämtlands och Härjedalens fångstland. - Järnåldern i Mittnorden. Ett symposium kring nya arkeologiska och ekologiska forskningsrön. Studier i Österbottens förhistoria nr 3. Vasa: Scriptum. 101-116. 
SUNDSTRÖM, JAN 1997: Järnålder i fångstlandet. - Inger Zachrisson et al. (eds). Möten $i$ gränsland. Samer og germaner i Mellanskandinavien. Stockholm: Statens historiska museum. 21-27.

SUNDSTRÖM, JAN \& FELDT 1989: Rapport över undersökning och återställning av skadad stensättning, fornl. nr. 10, Nyhem sn, Jämtland. Östersund: Jämtlands läns museum.

Sørensen, Marie Louise Stig 2015: 'Paradigm lost' - on the State of Typology within Archaeological Theory. - Kristian Kristiansen, Ladislav Šmedja \& Jan Turek (eds), Paradigm found. Archaeological Theory. Present, Past, Future. Essays in Honour of Evžen Neustupný. Oxford - Havertown: Oxbow Books. 84-94.

VV = Sampsa Holopainen, Petri Kallio \& Janne Saarikivi (eds) 2016: Verba Vagantur. Jorma Koivulehto in memoriam. MSFOu 274.

WeHLIn, JoАкім 2016: Fångstmarkens folk. - Arkeologi i Dalarna. Dalarna 2016. Dalarnas hembygdsbok 86. Falun: Dalarnas museum. 218-249.

WELINDER, STIG 2008. Jämtarna och samerna kom först. Östersund: Jamtli.

ZACHRISSON, INGER 1992: Can grave customs be taken over by one ethnic group from another? - Mihál Hoppal \& Juha Pentikäinen (eds), Northern religion and shamanism. Ethnologica Uralica 3. Helsinki - Budapest: Akadémiai kiadó - Finnish Literature Society. 108-114.

ZACHRISSON, INGER et al. (eds) 1997: Möten i Gränsland. Samer och germaner i Mellanskandinavien. Stockholm: Statens historiska museum.

ZACHRISSON, INGER 2009: Antlers on graves and sacrificial sites in South Saami society A.D. 1-1850: How to look upon South Saami culture and identity. - Máttut - Máddagat. The Roots of Saami ethnicities, Societies and Spaces/Places. Publications of Giellagas Institute 12. Oulu: Oulun yliopisto, Giellagas-instituutti. 134-149.

ZACHRISSON, INGER 2011: The Wider Context of Krankmårtenhögen. Comments on Camilla Olofsson: Making New Antlers: Depositions of Animal Skulls and Antlers as a Message of Regeneration in South Sámi Grave Contexts. Norwegian Archaeological Review 44 (2). 198-201.

ZACHRISSON, INGER 2014: Okänd och misskänd - skinnskrapan R. 416. Ombytta könsroller i Mellanskandinaviens yngre järnålder. Arkeologi i Norr 14. 


\section{Appendix I. The North-West Germanic and Proto-Scandinavian loan- words in South Saami}

The following information is provided (if possible): other Saami languages in which the word appears; the reconstructed PS and NwG/PScand forms of the word; the word in $\mathrm{ON}$, modern Scandinavian or other Germanic languages; and the primary and secondary denotative meanings. Only words with etymologies including NwG/PScand reconstruction are included in the lexical material. When a PS word is not reconstructed, it is marked with $(<$ PS). The words are presented in alphabetical order. The semantic category is given in parentheses.

\section{Notes}

In the literature, there seem to be different ways to mark the same phonetic feature: The phonetic quality of the graphemes $\partial$, d and $d$ is the same in the PScand language, and I will be using the grapheme d even if the original source uses another grapheme. (The initial phoneme and the phoneme after a nasal have always been $/ \mathrm{d} /$, and it will be marked with the grapheme $d$. The phonetic quality of the graphemes $\mathrm{b}$ and $\mathrm{b}$ is converging, and $\mathrm{I}$ have chosen to use the grapheme $\mathrm{b}$. The grapheme $\mathrm{V}$ is replaced with $\mathrm{g}$.

The qualities of the PScand phonemes $/ \mathrm{z} /$ and $/ \mathrm{R} /$ are not clear. It seems that they were not two separate phonemes, but rather that their quality is converging. (Schalin 2016, 253-255; 2017, 30-31.) However, in SaaS, the PScand phoneme(s) have two different sound substitutions, /s/ and /r/ (and sometimes $\varnothing$ ), of which the first is more common. If the sound substitute in SaaS is /s/, I have used the grapheme $\mathrm{z}$ in PScand; if SaaS has $/ r /$, the grapheme used is R. If there is $\varnothing$ in SaaS in place of the PScand phonemes $/ \mathrm{z} /$ or $/ \mathrm{R} /$ (usually at the end of a word), I have used the grapheme $\mathrm{z}$ in the PScand form. Heikkilä (2011, 68-69) notes that the development PScand /z/ > /R/ happened around $500 \mathrm{CE}$ after which the sound assimilated with the alveolar tremulant $\mathrm{r}$ by $1000 \mathrm{CE}$. If this is correct, PScand loanwords in SaaS with the phoneme $/ \mathrm{r} /$ $(<$ PScand $/ \mathrm{R} /$ ) should not be regarded as early PScand, nor should they be included in my data. However, as the quality of the phoneme is uncertain, I have included those loanwords in my data.

I am grateful for the enormous help I have received from Johan Schalin, who revised every single PScand form in my data, and from Jussi Ylikoski, who offered insightful comments on the Saami words.

aajhtere 'owner' (SaaS, SaaU, SaaL, SaaN) (humans and humans as members of society ${ }^{22}$ ) $(<\mathrm{PS}) \leftarrow$ PScand *aihtēr 'owner' $>$ ON attingi 'relative'

aajloe 'brain' (SaaS, SaaP) (body parts)

$<$ PS *äjlès 'brain' $\leftarrow$ PScand *hailan- > ON heili, I heili, N heile 'brain'.

The word is also found in the extinct Akkala Saami. 
aajmoe 'the other world (e.g. the realm of the dead); the great spirit' (SaaS, SaaU, SaaP, SaaL, SaaN, SaaI, SaaSk) (religion and beliefs)

$<\mathrm{PS}{ }^{\star} \bar{a} j m \bar{o}$ 'air, weather' $\leftarrow$ PScand ${ }^{\star}$ haima- $>$ Sw hem; E home.

In other Saami languages, the meanings refer to the world, air or natural phenomena; the meaning of the SaaS word has shifted to a religious phenomenon. (However, c.f. SaaN Jábmeáibmu 'world of the dead'.)

aajne 'the only one' (SaaS, SaaL, SaaN, SaaI, SaaSk) (adjectives)

$(<\mathrm{PS}) \leftarrow \mathrm{PScand}^{*}$ ainagaz $>\mathrm{ON}$ einga 'the only one'.

The PScand ${ }^{*}$ aina- is regular from the point of view of SaaS, but the PScand ${ }^{\star}$ - $g$ - is not found in the Saami forms of the word. Semantically, the etymology is clear. The word has more likely been borrowed from Finnish ainoa 'the only one', unless there are derivatives of the word in PScand that could be the original source of the borrowing. A possible explanation could be that the SaaS word was borrowed from a PScand form from which $\mathrm{ON}$ einn 'one (number)' descends. The form einn stems from Germanic *aina- (< PIE ${ }^{\star}$ oino 'the only one') (De Caprona 2013 s.v. en), which would result in SaaS aajne.

aajroe 'oar' (SaaS, SaaU, SaaP, SaaL, SaaN, SaaI, SaaSk, SaaK, SaaT) (vehicles and travelling)

$<\mathrm{PS}{ }^{\star}$ ājrō 'oar' $\leftarrow$ PScand *airō- > ON ár 'oar'.

aaksjoe 'axe' (SaaS, SaaU, SaaP, SaaL, SaaN, SaaI, SaaSk, SaaK, SaaT) (work-related words)

$<$ PS *ākšejñ 'axe' $\leftarrow$ PScand *akwisjō <*akwesjō > Sw yxa 'axe’.

Bergsland (1992, 7-8) has reconstructed the PS form as ${ }^{\star} \bar{a} k \bar{s}^{\prime} j \bar{j}$ and the PScand form as ${ }^{\star} a k^{w} u s j \bar{o}$ or ${ }^{\star} a k^{w} a s j \bar{o}$. Schalin (2018 pers. comm.) notes that ${ }^{\star} a k^{w} u s j \bar{o}$ would have lost its glide as in ${ }^{\star *} a k u s j o ̄$ in PScand. He agrees with Bjorvand \& Lindeman (2007 s.v. øks) on a reconstruction ${ }^{\star} a k w i s \bar{i}<^{*} a k w e s \bar{i}$, and the Saami forms could derive from another

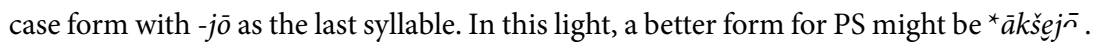

aalhtedh 'to prepare; work with animal skin' (SaaS, SaaU, SaaP, SaaL) (work-related words)

$(<\mathrm{PS}) \leftarrow$ PScand ${ }^{\star}$ altija- $>$ ON elta 'to hunt; to knead; to chase'.

The etymology is quite clear semantically as the ON meaning 'to knead' is a kind of preparing, and perhaps this could be a metaphor for 'work with animal skin'.

aarhtse 'eagle (SaaS, SaaU, SaaP, SaaL) (wild animals)

$(<\mathrm{PS}) \leftarrow$ ?PScand ${ }^{*}$ arnuz / ?*artnuz $>$ ON orn 'eagle'.

The word might have been borrowed separately into Southern Proto-Saami as there is an irregular sound change: The South Saami word would require the Proto-Scandinavian form ${ }^{*}$ artuz in order to be regular. The Pscand form ${ }^{\star}$ arnuz would result in SaaS aarne. Therefore, one could perhaps conceive that ${ }^{\star}$ arnuz in some dialects could have been pronounced with an epenthetic - $t$-: ${ }^{\star} a r^{t} n u z$ (Schalin 2018 pers. comm.). This form is seen in SaaP ärdnas; in SaaS and SaaU the nasal has disappeared. The etymology is regular at least in SaaL, perhaps also in SaaP. No PS form has been reconstructed for the word. 


\section{Minerva Piha}

aarjoehtidh 'to spare' (SaaS, SaaP, SaaL) (action processes)

$(<\mathrm{PS}) \leftarrow$ PScand ${ }^{\star}$ aizijan $>$ ON eira 'to spare'.

aarmoes 'wretched, unhappy' (SaaS, SaaU, SaaL) (adjectives)

$(<\mathrm{PS}) \leftarrow$ PScand *armaz $>$ ON armr 'nasty, poor, wretched'.

aartege, haartege 'shoulder' (SaaS, SaaU, SaaP, SaaL, SaaN, SaaI, SaaSk, SaaK) (body parts)

$<$ PS ${ }^{\star} a \bar{r} t i j \bar{a} /{ }^{\star}$ hārtijā 'shoulder' $\leftarrow \mathrm{NwG}^{\star}$ harđijō / ?Pscand ${ }^{\star}$ hardiju > ON herðar 'shoulder'; Old Sw hoerp.

The word in the western Saami languages usually has an initial $h$, while in eastern Saami the forms are without the $h$. The South Saami word is interesting as it has both forms: one without $h$ and one with it. The Saami word has been borrowed either from NorthWest Germanic or Proto-Scandinavian.

aassjoe 'hearth in a smithy' (SaaS, SaaL, SaaN) (buildings and constructions)

$<$ PS ${ }^{\star} \bar{a} s ̌ \bar{o} \leftarrow$ PScand ${ }^{\star}$ asjō- > Sw ässja 'hearth in a smithy'.

There is no consensus on the age of borrowing of the Saami word: SSA 1 (52) claims that the word stems from PG, while Sammallahti (1998: 128) deems it to be from the NwG stratum. Kallio (2012: 230) notes that it might be from either of these Germanic word strata, and Aikio (2006: 20) considers it to be PScand. Semantically, there are no complications. The secondary categories for the word are work-related words and fire.

aavtja 'forest' (SaaS, SaaU, SaaP, SaaL, SaaN) (flora)

$<\mathrm{PS}{ }^{\star} \bar{a} v c \ddot{e} \leftarrow \mathrm{NwG}^{\star}$ hagja > ON heggr; Sw hägg 'bird cherry'.

The word that refers to a specific tree in the Scandinavian languages has the general meaning of forest in SaaS. It seems that the meaning has expanded in SaaS, but the more northern Saami languages have kept the original meaning of 'bird cherry'. (See also $a w c ̌ a$.) The word is rather old, as even the SaaS form is without the initial $h$-. In SaaS, $h$-has developed earlier than in any other Saami languages, and it seems that the $h$ - was adopted into SaaS sometime before it developed in the more northern Saami languages. The secondary category for the word is terrain and landscape.

aavtjoe 'edge of a knife' (SaaS, SaaU, SaaP, SaaL, SaaN, SaaI, SaaSk, SaaK, SaaT) (workrelated words)

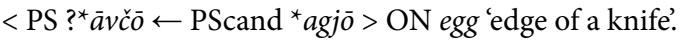

aegnieh (plural) 'chaff, husk' (SaaS, SaaL, SaaP) (agriculture and animal husbandry) $<\mathrm{PS}{ }^{\star} \bar{a} k n \bar{e} \leftarrow$ PScand ${ }^{\star}$ aganu $>$ ON ggn 'chaff, husk'.

The word could also be classified in the category of flora.

aejlege, aejlies 'holiday; Sunday' (SaaS, SaaU, SaaP, SaaL, SaaN) (religion and beliefs) $(<\mathrm{PS}) \leftarrow$ PScand ${ }^{\star}$ hailagaz $>\mathrm{ON}$ *heilag $(r)>$ Sw helig 'holy'. 
aepie 'open sea, high seas; (vast) swamp, bog' (SaaS, SaaN, SaaU, SaaP, SaaL, SaaI, SaaSk) (water and water systems)

$<\mathrm{PS}{ }^{\star} \bar{a} p \bar{e} \leftarrow$ PScand ${ }^{\star}$ haba- > ON haf'sea'; N, Sw hav 'sea'.

The secondary category for the word is terrain and landscape.

aerkie 'scared' (SaaS, SaaU, SaaP, SaaL, SaaN, SaaI, SaaSk, SaaK) (adjectives)

$<\mathrm{PS}{ }^{\star} \bar{a} r k \bar{e}$ 'timid, shy' $\leftarrow$ PScand ${ }^{\star} \operatorname{argaz}>\mathrm{ON}$ argr 'bad; angry; Sw arg 'angry'.

It's been assumed that the word is a loan from Fin arka 'timid, shy' (e.g. Lehtiranta 1989 s.v. $\bar{a} r k \bar{e})$ but the sound changes towards PScand and even PG ( $\left.{ }^{*} \arg a-z\right)$ are regular. The meaning of Finnish arka is perhaps closer to the meaning of the SaaS word than the Scandinavian meanings, although a scared person can appear to be angry, which may have motivated the semantic change.

aernie 'hearth (in a Saami hut)' (SaaS, SaaU, SaaP, SaaL, SaaN, SaaI, SaaSk) (buildings and constructions)

$<\mathrm{PS}{ }^{\star} \bar{a} r n \bar{e} \leftarrow \mathrm{PScand}{ }^{\star}$ arinaz / *aRina $>\mathrm{ON}$ arinn, Old Sw arin 'fireplace'.

aerpie 'legacy' (SaaS, SaaU, SaaP, SaaL, SaaN, SaaI, SaaSk) (humans and humans as members of society)

$<\mathrm{PS}{ }^{\star} \bar{a} r p \bar{e}$ 'legacy' $\leftarrow$ PScand ${ }^{\star}$ arba (or PG ${ }^{\star} a r b a-$ ) > ON arfr; Sw, N arv 'legacy'.

In SaaN there is another word, vuorbi 'lot, die; destiny' that stems from PG arba- (Koivulehto 1976: 249-251; 2002: 587) but the SaaS word aerpie could be borrowed also from PScand. Also, SaaN árbi 'legacy' is borrowed from this later form of ${ }^{\star}$ arba.

aevhkie 'benefit; happiness' (SaaS, SaaL, SaaN, SaaI, SaaSk) (conditions and changes ${ }^{23}$ ) $<\mathrm{PS}{ }^{\star} \bar{a} v k \bar{e} \leftarrow$ PScand ${ }^{*} a u k a n->\mathrm{ON}$ auki, cf. Sw öka 'to increase'.

The semantics of the etymology is somewhat complicated. Perhaps the SaaS meaning has shifted to 'benefit' and 'happiness' as the increase (of goods) was understood as increase in happiness and benefits.

aevlerge 'the pole in a Saami tent that holds the pot' (SaaS, SaaP, SaaL, SaaN, SaaI, SaaSk, SaaK, SaaT) (food and cookery)

$<$ PS ${ }^{\star} \bar{a} v l \bar{e} \leftarrow$ PScand ${ }^{\star}$ hāhilaz / ${ }^{\star}$ hāhlaz.

The etymology is uncertain as it is phonologically irregular. ON or modern Scandinavian cognates are not found so the comparison of the meanings is impossible. In Finnish, the word haahla 'trammel hook' stems from Germanic languages. The word could also be classified in the category of buildings and constructions.

aevries 'desolate place' (SaaS, SaaU, SaaP, SaaL, SaaN, SaaI, SaaSk) (relations in time and space $\left.^{24}\right)$

$(<\mathrm{PS}) \leftarrow$ PScand ${ }^{\star}$ aupa $-/{ }^{*}$ aupija $>\mathrm{ON}$ eyði; Sw öde 'desolate'.

Sammallahti $(1998,228)$ states that the word could be a PScand loan from *aupa- or PG loan from *aupija. However, according to Schalin (2018 pers. comm.), no additional syllable -ja is needed in the PG form. 


\section{Minerva Piha}

aevsie 'the cranial part of reindeer that is attached to antlers the and detaches when the antlers are cut off; the part of the skull that is between and around the antlers of a living reindeer' (SaaS, SaaU, SaaL, SaaN, SaaI) (reindeer and reindeer husbandry ${ }^{25}$ )

$<{ }^{\star} \bar{a} v s \bar{e}<\mathrm{NwS}$ āksē $\leftarrow$ NwG / PScand ${ }^{\star}$ hausa- > ON hauss; Sw hös 'skull'.

The lacking initial $h$ - in the SaaS word indicates that the word is an old loan from NwG rather than the PScand stratum. The semantics of the etymology is flawless, but there has been a contraction of the meaning in SaaS from the original general meaning of 'skull' to a specific part of a specific animal's skull. The word belongs also to the category of body parts.

$\grave{a} r^{a}{ }^{\prime} k u_{u}$ 'chest, coffin' (SaaS, SaaN, SaaI) (buildings and constructions)

$(<\mathrm{PS}) \leftarrow$ PScand ${ }^{\star}$ arku < ${ }^{*}$ arkō $>$ ON ork 'chest, coffin'; Old Sw ark.

The word has an old orthography used by Lagercrantz (1926: 36), and it cannot be found on newer dictionaries.

asspa 'aspen' (SaaS, SaaN) (flora)

$(<\mathrm{PS}) \leftarrow$ PScand *aspu > ON osp; Sw asp 'aspen'.

The orthography of the SaaS word is old, and the word is not found in newer dictionaries.

awča 'bird cherry' (SaaS, SaaU, SaaP, SaaL, SaaN) (flora)

$<\mathrm{PS}{ }^{\star} \bar{a} v \check{c} \ddot{e} \leftarrow \mathrm{NwG}{ }^{\star}$ hagja- > ON heggr, N hegg 'bird cherry'.

Awča is written in the old orthography, and the word cannot be found in the newer dictionaries in this meaning. The word stems from the same NwG word as the word aavtja 'forest'. (See aavtja.)

äwjic 'hay' (SaaS, SaaL, SaaN) (flora)

$(<$ PS $) \leftarrow$ PScand *hauja- > ON hey 'hay'.

The orthography is old, and the word cannot be found in newer dictionaries. As the initial $h$-seems to be lacking, the word is rather old a loan. The word could secondarily be placed in the category of agriculture and animal husbandry.

baante 'band (e.g. in a cassette)' (SaaS, SaaP, SaaL, SaaI) (work-related words) $(<\mathrm{PS}) \leftarrow$ PScand ${ }^{\star}$ banda $>$ ON band 'knot, band'.

baarhkoe 'bark' (SaaS, SaaU, SaaP, SaaL, SaaN, SaaI, SaaSk, SaaK, SaaT) (flora) $<$ PS ${ }^{\star}$ pärkkn 'bark' $\leftarrow$ PScand ${ }^{\star}$ barku- > ON borkr; Sw bark.

baaroe 'wave' (SaaS, SaaU, SaaP, SaaL, SaaN, SaaI, SaaSk) (water and water systems) $<$ PS *pārō 'wave’ $\leftarrow$ PScand ` bārōn- > ON bára 'wave’.

baernie 'boy, son' (SaaS, SaaU, SaaP, SaaL, SaaN, SaaI, SaaSk, SaaK, SaaT) (humans and humans as members of society)

$<{ }^{\star}$ pārnē 'boy, child' $\leftarrow$ PScand ${ }^{\star}$ barna $>$ ON, N, Sw, I barn 'child'.

The semantics of the etymology is clear, although in Saami languages, the word usually refers to a boy child. In eastern Saami languages, the meaning is also 'child'. 
bearkoe 'meat; food meat' (SaaS, SaaU, SaaP, SaaL, SaaP, SaaI, SaaK) (food and cookery) < PS *pērk̄̄ / ‘pērkō / ‘pierkō 'meat; food' $\leftarrow$ PScand ${ }^{\star}$ bergō- > ON bjorg 'help, rescue; food'.

betnie 'bottom (of a lake)' (SaaS, SaaU, SaaP, SaaL, SaaN, SaaI, SaaSk, SaaK, SaaT) (water and water systems)

$<$ PS ${ }^{\star}$ ponnē 'bottom' $\leftarrow$ Pscand ? ${ }^{\star}$ butna- $\left(<\mathrm{G}{ }^{\star}\right.$ budma- / ${ }^{\star}$ butma- $)>\mathrm{ON}$ botn; N botn; Sw botten 'bottom'.

Bjorvand and Lindeman (2007 s.v. botn) give a Germanic reconstruction for a word referring to 'bottom': ${ }^{\star} b u d m a-/{ }^{\star} b u t m a$. There is no more detailed explanation about the strata to which the word belongs. As there is an internal $-(t / n) n$-in the Saami words, the PScand reconstruction, from the SaaS perspective, should be ${ }^{\star} b u t n a-$. As for the first syllable vowel, the other Saami languages seem to be phonetically regular, but the SaaS first-syllable -e- is irregular.

buvrie 'storage building' (SaaS, SaaL, SaaN, SaaI, SaaSk, SaaK, SaaT) (buildings and constructions)

$<$ PS * puvrē < ${ }^{*}$ puvrā 'shed' $\leftarrow$ PScand ${ }^{\star}$ būra- > ON búr 'a storage building' N, Sw bur 'hutch, jail, cage'.

daajje 'dough' (SaaS, SaaU, SaaP, SaaL, SaaN, SaaI, SaaSk, SaaK, SaaT) (food and cookery)

$(<\mathrm{PS}) \leftarrow$ PScand ${ }^{\star}$ daigaz, ${ }^{\star}$ daigiz- $>\mathrm{ON}$ deigr 'soft; watery', N deig 'dough'.

PScand ${ }^{\star}$ daigiz- is the stem used with cases other than nominative or accusative. The form ${ }^{*}$ daigiz is regular with the vowel in the last syllable of the SaaS word. It should be noted that the internal $k$ is missing in the SaaS word and therefore has an irregular correspondence to PS ${ }^{\star} t a \bar{j} k e$ (the $k$ is found in other Saami languages).

daatje 'Norwegian or Swede' (SaaS, SaaU, SaaP, SaaL, SaaN, SaaI, SaaSk) (humans and humans as members of society)

$<$ PS *tānče $\leftarrow$ PScand *daniz /?*danjV- > ON Danir (pl.) 'Danes'; Sw dan 'Dane', dansk 'Danish'.

Sammallahti (1998: 236) suggests that the Saami words originate from PScand ${ }^{\star} d a n j V$-, and Aikio (2009: 281) marks the form with a question mark. Schalin (2018 pers. comm.) notes that there should not be $-j$ - in the PScand form. He suggests an i-stem, e.g. daniz (pl). The semantic shift from Danes in Scandinavian to Norwegians and Swedes in Saami is understandable, as it is probable that the Saami had much more contact with Norwegians and Swedes than with Danes. In SaaN and the more eastern languages, the word refers to Norwegians, as the speakers probably did not have much to do with Swedes who lived farther in the South. In Lule Saami, it can mean any person who is not Saami.

daerpies 'useful' (SaaS, SaaU, SaaP, SaaL, SaaN, SaaI, SaaSk) (adjectives)

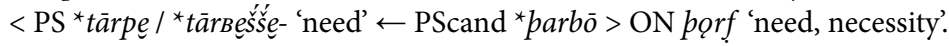




\section{Minerva Piha}

dahpe 'sheath' (SaaS, SaaP, SaaL, SaaN, SaaI, SaaSk, SaaK, SaaT) (work-related words)

$<\mathrm{PS}^{\star}$ toppe $\leftarrow \mathrm{NwG}^{*}$ duppā.

Aikio (2006: 24) notes that the word is borrowed from PG $\left(<^{*} d u p p a-z\right)$. Sammallahti $(1998,128)$ gives NwG as the donor language. Phonetically both donors are possible. I have not been able to find cognates in ON or modern Scandinavian languages, though there are some from e.g. Middle Low German (dop(pe) 'sheath') (Koivulehto 1981: 77-78; Aikio 2006: 24).

davgh 'sure; however; though' (SaaS, SaaU, SaaP, SaaL, SaaN) (other words ${ }^{26}$ ) $<$ ?PS ${ }^{\star} t \bar{a} v k /{ }^{\star} d \bar{a} v k \leftarrow$ PScand ${ }^{\star}$ pauh $>$ ON pág, pó 'then, on the other hand'. The word cannot be found in newer dictionaries in any form. Jussi Ylikoski (2018 pers. comm.) suggests that davgh could be connected to the interrogative word dagke, dagkh. The word has a somewhat skeptical nuance, e.g. Dagke dihte båata? 'She is not coming, is she?' (cf. Finnish tokko).

deemedh 'to tame (esp. a reindeer stag into a draught animal)' (SaaS, SaaU, SaaP, SaaL, SaaN, SaaI, SaaSk) (reindeer and reindeer husbandry)

$?<$ PS ${ }^{\star}$ tāme 'to tame' $\leftarrow$ PScand ${ }^{\star}$ tamja- $>$ ON temja 'to tame'.

The word seems irregular in SaaS, as PS ${ }^{\star} \bar{a}$ usually corresponds to SaaS aa / ae. The word is regular in the other Saami languages. The SaaS word might be a later, separate loan from $\mathrm{ON}$.

ditnie 'tin, pewter' (SaaS, SaaU, SaaP, SaaL, SaaN, SaaI, SaaSk, SaaK, SaaT) (work-related words)

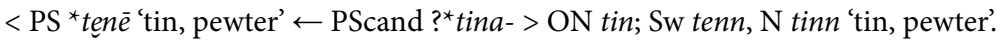

dovres, dovrehke 'expensive' (SaaS, SaaU, SaaP, SaaL, SaaI) (adjectives)

$<$ ?PS *diuvress $\leftarrow$ ?PScand *diurijaz / *diuriz > ON dýrr; Sw dyr 'expensive'.

The etymology is unclear. It is phonetically regular in other Saami languages, e.g. SaaN divrras, but SaaS form is irregular. It might have been separately borrowed. Semantically the etymology is flawless.

eajma 'reindeer doe who wanders where it wants' (SaaS) (reindeer and reindeer husbandry)

$<$ PS *eajmēs / ${ }^{\star}$ eajmā 'a fool; one who likes to be alone; a lone animal' $\leftarrow$ PScand ${ }^{\star}$ haimiskaz > ON heimskr 'stupid, foolish, silly'; I heimskur 'stupid, ignorant'; Sw hemsk 'awful'. The Saami word has been borrowed from an intermediate state of the PScand ${ }^{\star} a i>\mathrm{ON}$ *ea (Aikio 2009: 184). For the semantics of the etymology, see eajmeske.

dälja 'sitting board in a boat' (SaaS, SaaU, SaaP, SaaL, SaaN, SaaI, SaaSk, SaaK) (vehicles and travelling)

$<$ PS ${ }^{\star}$ tilja 'thwart' $\leftarrow$ PScand piljōn $>$ ON pilja, N tilje 'deckboard on a ship'.

The word is written in the old orthography and cannot be found in newer SaaS dictionaries. 


\section{Combining Proto-Scandinavian loanword strata in South Saami ...}

eajmeske 'one who wants to be alone (human or reindeer)' (SaaS, SaaN) (adjectives) $<$ PS *eajmāske $\leftarrow$ PScand ${ }^{\star}$ haimiskaz > ON heimskr 'stupid, foolish, silly'; I heimskur 'stupid, ignorant'; Sw hemsk 'awful'.

In other Saami languages, the meaning is closer to that of ON and modern Scandinavian languages, but Aikio (2009: 184) notes that the PScand word is a derivative of ${ }^{\star}$ haima'home', and the semantic development of the word has been: 'one who stays home all the time' > 'an odd, reclusive person' > 'fool'. The SaaS word has kept the earlier meanings of the PScand word. The secondary categories of the word are humans and humans as members of society, or reindeer and reindeer husbandry. (See also eajma).

faala, faelies 'whale' (SaaS, SaaU, SaaP, SaaL, SaaP, SaaI, SaaSk, SaaK, SaaT) (wild animals)

$<$ PS *vālēs / *vālās 'whale' $\leftarrow$ PScand *hwalaz > ON hvalr, Sw val 'whale'.

faaroe 'trip; party; travelling company' (SaaS, SaaU, SaaP, SaaL, SaaN, SaaI, SaaSk, SaaK, SaaT) (vehicles and travelling)

$<\mathrm{NwS}{ }^{\star} f a \bar{r} r \bar{o}$ 'travelling companion; trip’ $\leftarrow$ PScand ${ }^{\star}$ farō- > ON fọr 'journey, journeying'.

The word was borrowed into SaaS after PS had been divided into three dialects: Southwest Saami, Northwest Saami and East Saami (Aikio 2012, 77). The ES word form would be *vārō.

faastoe 'lent' (SaaS, SaaP, SaaL, SaaN, SaaI, SaaSk) (religion and beliefs)

$(<\mathrm{PS}) \leftarrow$ Pscand ${ }^{\star}$ fastōn- $>$ ON fasta.

The word has not been previously etymologized, but the etymological connection to Proto-Scandinavian is phonologically and semantically clear.

fealloe 'plank, board, chopping board' (SaaS, SaaP, SaaL, SaaN) (work-related words)

$<$ PS ${ }^{\star}$ fèll $\bar{\nu}{ }^{*}$ fiello $\leftarrow$ PScand ${ }^{\star}$ felhō / ${ }^{\star}$ felhu > ON fjol 'plank; board, table'; N fjøl; Sw fjöl (dial fjäl, fjel).

PS ${ }^{*}-\bar{e}-/^{*}-i e$ - usually is $-i e$ - also in SaaS. Germanic ${ }^{*}-e$ - developed into SaaS -ea- during the PG phase (Koivulehto 2002: 589), and therefore the SaaS word might be a separate loan from PScand. The SaaL and SaaN words are borrowed from PScand. The secondary category of the SaaS word is food and cookery.

fierve 'low tide; a beach that surfaces during low tide' (SaaS, SaaU, SaaP, SaaL, SaaN, SaaI, SaaSk) (water and water systems)

$<$ PS ${ }^{\star}$ fiervā/e $/ \ddot{e} \leftarrow$ PScand ${ }^{\star}$ ferwō $(n)$ - > ON fjara 'low tide, beach revealed by low tide'. The secondary category of the word is terrain and landscape.

fuelhkie 'family' (SaaU, SaaP, SaaL, SaaN, SaaI) (humans and humans as members of society)

$(<\mathrm{PS}) \leftarrow$ PScand ${ }^{\star}$ folka $/{ }^{\star}$ fulka $>\mathrm{ON}, \mathrm{N}$, Sw folk 'people'.

gaahkoe 'bread; traditional thin unleavened bread' (SaaS, SaaU, SaaP, SaaL, SaaN, SaaI, SaaSk) (food and cookery)

$<\mathrm{PS}{ }^{\star} k \bar{a} k k^{n} `$ bread' $\leftarrow$ PScand ${ }^{\star} k a k o ̄ n->\mathrm{ON}{ }^{\star} k a k a$; Sw kaka 'cake, biscuit, cookie’; N kake. 


\section{Minerva Piha}

gaajedidh 'to draw away; disappear' (SaaS, SaaU, SaaP, SaaL, SaaN, SaaI, SaaSk, SaaK) (action processes)

$<$ PS ${ }^{\star} k a \bar{j}$ te $-/{ }^{*}$ käjete $-\leftarrow$ PG / PScand ${ }^{*}$ skaida- > Gothic skaidan, German scheiden 'to divide, to separate'.

According to Aikio (2009: 76), the German word has an intransitive meaning 'to part, depart, leave' and Gothic has a reflexive conjugation that has the same meaning. Those meanings come close to the meaning of the Saami words. The loan is a slightly older than most PScand loans, as the initial PScand ${ }^{\star} s k$ - is not preserved in the Saami languages. Perhaps it is a NwG loan.

gaajhtse 'goat' (SaaS, SaaU, SaaP, SaaL, SaaN, SaaI, SaaSk) (agriculture and animal husbandry)

$<\mathrm{PS}{ }^{\star} k a \overline{a j} c c e<<<$ kājttes $/{ }^{\star} k a \bar{j} j c e \leftarrow$ PScand ${ }^{\star}$ gaitiz (pl.) / ${ }^{\star}$ gaita - / $^{\star}$ gaitz > ON geit 'vuohi'; Sw get 'goat'.

Koivulehto (2002: 589) states that the word is borrowed from PScand plural form ${ }^{\star}$ gaitiz; Aikio $(2009,106)$ suggests the stem ${ }^{\star}$ gaita- as the orginal. In my opinion, the nominative singular form ${ }^{\star}$ gaitz could well be the original.

gaaltije 'spring' (SaaS, SaaL, SaaN, SaaI, SaaSk, SaaK, SaaT) (water and water systems) $<$ PS ${ }^{\star} k a \bar{l} t i j \bar{a} /{ }^{*} k a \bar{a} l t e \bar{j} \bar{o}$ 'ice hole; spring' $\leftarrow$ PScand ${ }^{*} k a l d i o ̄ n->$ ON kelda 'well, spring'.

gaavnedh 'to find'(SaaS, SaaU, SaaP, SaaL, SaaN, SaaI, SaaSk, SaaK, SaaT) (conditions and changes)

$<$ PS ${ }^{\star} k \bar{a} v n e$ 'to find' $\leftarrow$ PScand ${ }^{\star}$ gagnija- / gaganja- > ON gegna 'to object, to defend; to meet, to encounter'.

The semantics of the etymology is quite understandable as the ON meanings of 'to meet' and 'to encounter' can be understood as 'to find'.

gaavnoe 'find' (SaaS, SaaU, SaaP, SaaL, SaaN, SaaI, SaaSk, SaaK) (other words)

$<$ PS ${ }^{\star} k \bar{a} v n \bar{e}<{ }^{\star} k \bar{a} v n \bar{a}$ 'object, thing' < $\leftarrow$ PScand ${ }^{\star}$ gagna- > ON gagn 'usage; achieve; cutlery'; Sw gagn 'use'; gagna 'to be useful.'

In Saami languages other than SaaS, the word has the meanings 'item' and 'thing'; in SaaI, even 'magic'. There has been a semantic shift in the SaaS word that is rather difficult to explain. Perhaps a find has been thought to be of good use, which would explain the shift. The word could also be derived from the verb gaavnedh, and thus the meaning would derive from there (Schalin 2018 pers. comm.).

gaejmie 'dusk; dawn' (SaaS, SaaL, SaaN) (natural phenomena)

$<\mathrm{PS}{ }^{\star} k a \bar{j} m V /{ }^{\star} k a \bar{j} j m \bar{e} \leftarrow$ PScand ${ }^{\star}$ skaim $V$ - > Sw dial. skäim 'dusk; dawn'.

gaejsie 'high and steep mountain' (SaaS, SaaP, SaaL, SaaN, SaaI, SaaSk) (terrain and landscape)

$<$ PS ${ }^{*} k \bar{a} j s \bar{e} \leftarrow$ PScand * gaizaz 'spear' > ON geirr 'spear'.

A high and steep mountain may remind a spear, so the semantic shift has a metaphorical nature. The PScand word ${ }^{*}$ gaizan- has meant a triangular stake, tip or spire or an object shaped like them, which may also have affected the semantics of the SaaS word. 


\section{Combining Proto-Scandinavian loanword strata in South Saami ...}

gaellies 'old man' (SaaS, SaaU, SaaP, SaaL, SaaN, SaaI, SaaSk, SaaT, SaaK) (humans and humans as members of society)

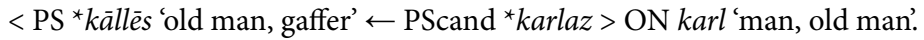

gaelpie 'calf of a cow' (SaaS, SaaU, SaaP, SaaL, SaaN, SaaI, SaaSk) (agriculture and animal husbandry)

$<$ PS ? $^{\star} k \bar{a} l p \bar{e} \leftarrow$ PScand ${ }^{\star} k a l \hbar a z>$ ON kalfr 'calf of a cow'.

The second syllable PScand ${ }^{\star} a>\mathrm{PS}^{\star} \bar{e}$ is unexpected.

gaerie '(wooden) bowl' (SaaS, SaaU, SaaP, SaaL, SaaN, SaaI, SaaSk, SaaK, SaaT) (food and cookery)

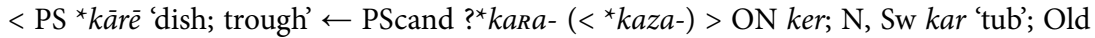
High German kar; Gothic kas 'vessel'.

The word was likely borrowed into SaaS after the (hypothetical) PScand change ${ }^{\star} z>{ }^{*}$, but before the change Pscand ${ }^{\star} a>\mathrm{ON} e$. The word refers to quite similar dish in both Saami and Scandinavian.

gaertie 'reindeer corral' (SaaS, SaaL, SaaP, SaaT, SaaU, SaaN, SaaI, SaaSk, SaaK) (reindeer and reindeer husbandry)

$<$ PS *kārtēe < * early PS kārtā 'fence; curve' $\leftarrow$ PScand * garda- > ON garðr 'fence; yard, garden; enclosure'.

The second syllable PScand ${ }^{*} a>$ PS ${ }^{*} \bar{e}$ is unexpected. The semantics of the etymology are transparent as the meaning refers to a fenced area in both Saami and Scandinavian. In SaaS, the meaning has contracted to mean a fenced area for a specific animal. In SaaI and the eastern languages the meaning is also 'trap'. The secondary semantic category is buildings and constructions.

gaessie 'colostrum, first milk' (SaaS, SaaU, SaaP, SaaL, SaaN, SaaI, SaaSk, SaaK, SaaT) (other words)

$<\mathrm{PS}{ }^{\star} k \bar{a} s s \bar{e}$ 'resin' $\leftarrow \mathrm{NwG} / \mathrm{PS}$ cand ${ }^{\star} k a \bar{a} s j a->\mathrm{I}$ kasir, N kjoese; Sw (dial.) käs(e) 'cheese rennet'.

The meanings of the SaaS word and modern Scandinavian languages are close enough to each other to be clear. In many Saami languages the meaning is 'resin; earwax'.

gealoe 'throat; larynx' (SaaS) (body parts)

$<$ PS ${ }^{\star} k \bar{e} l \bar{s} \leftarrow$ PScand ${ }^{\star} k e l o ̄ n$ - 'throat'.

The word is not known in Scandinavian languages.

gearhka 'throat; larynx' (SaaS) (body parts)

$(<\mathrm{PS}) \leftarrow$ PScand ${ }^{\star} k w e r k o ̄>$ ON kverk 'throat'.

giëhtjedh 'to see; to watch (over one's reindeer, etc.)' (SaaS, SaaU, SaaP, SaaL, SaaN, SaaI, SaaSk, SaaK, SaaT) (action processes)

$<$ ?PS ${ }^{*} k \bar{\varepsilon} c$ će $e$ NwG ${ }^{*}$ gātjana 'to look after' > ON gjoete.

The first syllable vowels in South Saami word points to PS ${ }^{\star} e{ }^{*} i e$, but the other Saami languages require $\mathrm{PS}^{\star} \varepsilon>^{\star} e a$. The word might be even earlier loan and borrowed from 


\section{Minerva Piha}

Pre-NwG form where the first syllable ${ }^{*} \bar{e}$ had not yet developed into $\mathrm{NwG}^{*} \bar{a}$. It is possible that the word is a separate loan in South Saami (J. Häkkinen 2017 pers. comm.). However, if the word is an older loan than NwG/PScand, it could have participated to the sound change ${ }^{\star} \varepsilon>\mathrm{SaaN}$ (and other Saami languages) ${ }^{\star} e a / \mathrm{SaaS}{ }^{*} i e$.

gïeles 'keel; long and narrow mountain ridge' (SaaS, SaaP, SaaL, SaaN, SaaI, SaaK, SaaT) (terrain and landscape)

$<$ PS ${ }^{\star}$ kieles $\leftarrow$ PScand ${ }^{\star} k e l u z>$ ON kjọlr 'keel; keel-shaped mountain range'.

goeme, guemie, gåemie 'palate' (SaaS, SaaU, SaaP, SaaL, SaaN, SaaI, SaaSk, SaaK, SaaT) (body parts)

$<$ PS ^kōmē 'palate’ $\leftarrow$ PScand gōma- > ON gómr; N, Sw gom 'palate'.

govse 'cow' (SaaS, SaaU, SaaP, SaaL, SaaN, SaaI, SaaSk, SaaK) (agriculture and animal husbandry)

$<$ PS ${ }^{\star} k u s e<{ }^{\star} k \bar{u} s e \leftarrow \mathrm{NwG}^{\star} k u ̈ z /$ PScand ${ }^{\star} k \bar{u} z>\mathrm{ON} k y ́ r$; Sw ko 'cow'.

haajhke 'pine tree; tall and old tree (any species); rough and thick pole' (SaaS, SaaU, SaaP, SaaL, SaaN, SaaI, SaaSk, SaaT) (flora)

$<$ PS *hājkke $\leftarrow$ PScand *aik- > ON eik; Sw ek 'oak'

The meaning refers to a certain tree in both the Saami and Scandinavian languages, but the Saami word has shifted to mean a pine tree. This may be because in the boreal forest area where the Saami people dwelled, oak was not a common tree species. In SaaS, the word can refer to any tree species in certain contexts.

haallode 'slanting' (SaaS, SaaU, SaaP, SaaL, SaaN, SaaSk) (adjectives)

$<\mathrm{PS} *(h) \bar{a} l \bar{n}$ 'slanting' $\leftarrow$ PScand ${ }^{*}$ halpaz > ON hallr 'slanting'; Sw, N hall.

The PS form is irregular from the perspective of the PScand form. The PS form ${ }^{\star} \bar{a} \bar{n}$, presented by Lehtiranta (1989 s.v. $\left.\bar{a} \bar{n}^{\circ}\right)$ works for SaaL ((h)allō), SaaN (álu-) and SaaSk (ällad) words, but the more southern Saami languages require intial ${ }^{\star} h$ in the protoform. The etymology is flawless semantically.

haame 'antler-less reindeer cow' (SaaS, SaaU, SaaP, SaaL, SaaN, SaaI, SaaSk, SaaK, SaaT) (reindeer and reindeer husbandry)

$<$ PS ${ }^{\star}$ häme $\leftarrow$ PScand ${ }^{\star}$ hamala- > ON hamla 'to cripple, to disable'; cf. also Old E hamola 'one whose head is shaven clean'.

The word may have been borrowed separately into SaaS, as most other Saami languages require PS form ${ }^{\star} \bar{a} m \bar{e}(l \bar{e})$. As also SaaU requires the PS form without initial $h$ - but SaaP does not, it complicates things. Nevertheless, SaaS requires a PS form with initial ${ }^{\star} h$-. The second syllable development PScand ${ }^{\star} a>$ PS $\bar{e}$ is unexpected but not unheard of. Semantically, there is a connection between SaaS and ON words.

haelmie 'straw, thatch' (SaaS, SaaP, SaaL, SaaN) (flora)

$<$ PS ${ }^{\star}$ hälmē $\leftarrow$ PScand ${ }^{\star}$ halma- > ON halmr'straw, thatch'.

The second syllable development PScand ${ }^{\star} a>$ PS $\bar{e}$ is unexpected. 


\section{Combining Proto-Scandinavian loanword strata in South Saami ...}

haepkie 'falcon, hawk' (SaaS, SaaP, SaaL, SaaN) (wild animals)

$<\mathrm{PS}$ ?^hāpaka / ?hāpakē $\leftarrow$ PScand ${ }^{\star} h a \hbar u k a z>$ ON haukr 'hawk'.

The SaaS form requires PS form ${ }^{\star} h a \bar{p} p a k \bar{e}$ as $\mathrm{PS}{ }^{*} \bar{e}>\mathrm{SaaS} i e$.

hiessjie 'wooden frame for drying hay; hay rack' (SaaS, SaaU, SaaP, SaaN) (agriculture and animal husbandry)

$(<\mathrm{PS}) \leftarrow$ late PScand ${ }^{\star}$ hesja (< PScand $\left.{ }^{\star} h a s j o ̄(n)\right)>$ I hes, hesja, Sw hässja 'hay rack'.

Koivulehto $(1999 \mathrm{~b}, 14)$ has deduced the SaaN ássi to originate from PScand. SaaS hiessjie, however, could perhaps be a later loan as the SaaS first syllable diphthong would require PScand *-e- (Koivulehto 2002: 589). Therefore, it is possible that the word has been borrowed separately into SaaS a bit later than into SaaN. The word could also be classified in the category of buildings and construction.

hovme 'snowfall; snowstorm'. (SaaS, SaaU, SaaP, SaaI) (natural phenomena)

$<$ PS *hume $\leftarrow$ PScand ${ }^{\star}$ huma- > ON húm 'dim; gloomy; half dark'.

The word has been borrowed separately into SaaS. In other Saami languages, the forms require one of the following PS forms: ${ }^{\star} u m V-\sim o m V-/{ }^{\star} h u m V-\sim$ hom $V$-. (Fore more specific description, see Aikio 2009: 173-174.) Other SaaS words borrowed from the same PScand form are humhkie umhkie $\left(<^{*}(h) u m k k \bar{e}\right)$ 'dark snowy weather in daytime in which the terrain looks level' and amhkes $\sim$ åmhkes ( $<{ }^{*}$ omkkes) 'cloudy and dark (of weather)' (Aikio 2009: 173).

ibje 'dust' (SaaS) (natural phenomena)

$<$ PS *ipjë $\leftarrow$ PScand ${ }^{\star}$ hiuja / ${ }^{\star}$ hiwja- > ON hý feather, colour (of the face)'; Sw hy 'skin, complexion; appearance, colour (of face)'; I hy' 'down; fine hair; small husks; dust'.

The word is rather an old loan as the initial $h$-is lacking in SaaS. Aikio (2006: 24) notes that the etymology is semantically flawless as in I there is the same meaning of dust as in SaaS.

klaajpoe 'mountain peak that peeks out of water or hangs over a fall'. (SaaS, SaaU, SaaP, SaaL) (terrain and landscape)

$(<\mathrm{PS}) \leftarrow$ PScand ${ }^{\star}$ klaibō.

The word has been borrowed separately into southern Saami languages and SaaP. The SaaL form stems from a PS form without the initial $k$; the other, more southern languages require the $k$ in the PS form.

klahtje 'horsefly' (SaaS, SaaU, SaaL, SaaN) (wild animals)

$<$ PS ?*klāvčă/e $\leftarrow$ PScand *klaggjan > ON kleggi 'horsefly'.

The word has been borrowed separately into SaaS and SaaU. The SaaL and SaaN words require a PS form ${ }^{\star}(s) l \bar{a} v \bar{c} \bar{a}$, but as there is an initial $k$-, it is not probable that the protoform for the southern Saami languages has begun with (s)l-. (See Aikio 2012: 110.)

kraavhtse 'porridge' (SaaS, SaaU, SaaL, SaaN, SaaI) (food and cookery)

$<$ PS ${ }^{\star} k r a \bar{v} v c c e<{ }^{*} k r a \bar{v} t t e \ddot{s} \leftarrow$ PScand ${ }^{*}$ grautaz $>$ ON grautr, N grøt, Sw gröt 'porridge'.

The word has been borrowed separately into southern Saami languages (Aikio 2012:

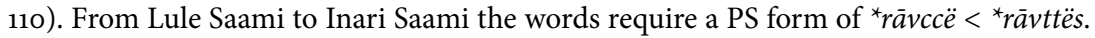




\section{Minerva Piha}

Koivulehto (1999b: 7) states the meaning of the Saami words to be 'soup made of fish roe. However, the word is generally used to refer to porridge in many Saami languages, SaaS among them.

kraesie 'grass; the content of stomach or intestines' (SaaS, SaaU; SaaP, SaaL, SaaN, SaaI, SaaSk, SaaK, SaaT) (flora)

< PS *krāsēe 'grass; flower; plant' Ł PScand *grasa- > ON, N gras; Sw gräs 'grass.'

According to Aikio (2012: 110) other variants of the same word in SaaS are kraessjie and

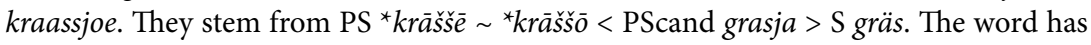
been borrowed separately into South and Ume Saami. The northern and eastern PS form of the word would be ${ }^{\star} r \bar{s} s \bar{e}$. The semantic relationship of the word to the meaning in the Scandinavian languages is transparent.

kraevies 'gray' (SaaS, SaaU, SaaP, SaaL, SaaN) (adjectives)

$<$ PS *krāvēs $\leftarrow$ PScand *grāvaz > ON grár; Sw grå 'gray'.

krievvie 'reindeer herd (herded by a reindeer shepherd)' (SaaS, SaaU) (reindeer and reindeer husbandry)

$<$ PS ${ }^{\star} k r i e v v e \bar{e} \leftarrow$ PScand ${ }^{*} k r e u(h)>\mathrm{N}$ dial. $k r u$ 'a small corral for cattle'.

The etymology is semantically complicated. As animal husbandry was a less common livelihood for the Saami than reindeer pastoralism, it is possible that as the word was borrowed, the meaning of it shifted to refer to a more familiar phenomenon. The meaning of a reindeer herd herded by a shepherd could be seen as a metaphor of a fenced area or man-controlled animals. Bergsland (1988: 162) notes that the SaaS expression krievvien sisnie means 'within a reindeer herd kept in a corral or on a cape of lake. This brings the meanings of the Scandinavian and SaaS words closer to each other.

kruana, kråånehke 'green' (SaaS, SaaU, SaaP, SaaL, SaaN, SaaI, SaaSk, Saak, SaaT) (adjectives)

$<\mathrm{PS}{ }^{*}$ rōne / * ruone 'green' $\leftarrow$ PScand * grōniz > ON grœnn; N grønn; Sw grön 'green'.

laaffa 'flea' (SaaS, SaaP, SaaL) (wild animals)

$<\mathrm{NwS}$ *läffēs $\leftarrow$ PScand *flauha- > ON fló 'flea'.

laajkoe 'debt' (SaaS, SaaU, SaaP, SaaL, SaaN) (humans and humans as members of society)

$<$ PS ${ }^{\star}$ lajkō $\leftarrow$ PScand *laigōn $>$ ON leiga 'rent', Sw lega 'rent'.

In many Saami languages, the word refers to rent, but in SaaS, the meaning has slightly shifted. The word could belong to the category of trade. However, the connection between the SaaS and Scandinavian words is clear.

laajroe 'road, route' (SaaS, SaaU, SaaP, SaaN, SaaL, SaaI, SaaSk, SaaK) (vehicles and travelling)

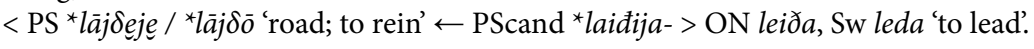


laampe 'lamb' (SaaS, SaaU, SaaP, SaaN, SaaI, SaaSk) (agriculture and animal husbandry) $(<\mathrm{PS}) \leftarrow$ PScand ${ }^{*}$ lambaz $>$ Old Sw lamb.

laavkedh 'to join' (SaaS, SaaU, SaaP, SaaL, SaaN, SaaI, SaaSk, SaaK, SaaT) (action processes)

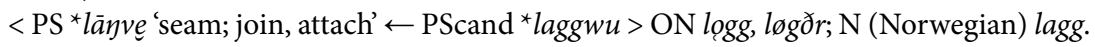

laedtie 'farmer; person with fixed residence' (SaaS, SaaU, SaaP, SaaL, SaaN, SaaI, SaaSk, SaaK) (humans and humans as members of society)

$<$ PS *lāntē 'stranger' $\leftarrow$ PScand *landa- > ON land 'land, earth'.

The semantic change from land to farmer is quite understandable. In Swedish, for example, farmer is lantbrukare, literally 'land user', and countryside is landsbygd 'land area' (with buildings as bygd $\leftarrow$ bygga 'to build'). The word could as well be classified in agriculture and animal husbandry.

laejjies 'thin; mild (of coffee); not enough salt (on food)' (SaaS, SaaU, SaaP, SaaL, SaaN, SaaI; SaaSk, SaaK) (food and cookery)

$<$ PS ${ }^{\star} l a \bar{j} v \bar{e} \leftarrow$ PScand ${ }^{*}$ slaiwaz > ON sloer, sljór 'blunt, dull.

The etymology is rather straightforward, although in Saami the meanings are related to taste and food. The SaaL word slájvve requires PS *släjvē.

laejpie 'bread' (SaaS, SaaU, SaaP, SaaL, SaaN) (food and cookery)

$<$ PS läjpe $\leftarrow$ PScand ${ }^{\star}$ hlaiba $>$ ON hleifr 'bread, round unleavened bread'.

Again, the second syllable development PScand ${ }^{\star} a>$ PS $\bar{e}$ is rather unexpected.

laejrie 'clay' (SaaU, SaaP, SaaL, SaaN, SaaI) (terrain and landscape)

$<$ PS *läirē $\leftarrow$ PScand *laiRa > ON leirr, N leir, Sw lera 'clay'.

laektedh 'to make thoroughly wet' (SaaS, SaaN (SaaSk)) (action processes)

$?<$ PS ${ }^{\star}$ lāvtte $\leftarrow$ PScand * blauta - > ON blautr 'soft, weak, timid'; N bløt, Sw blöt 'soft, wet'. Phonetically it is a somewhat uncertain etymology, and the SaaS word may be a borrowing from the more northern Saami languages, e.g. SaaN láktat 'to get damp; damp' (see Aikio 2009: 191-192).

lihtse 'joint' (SaaS, SaaU, SaaP, SaaL, SaaN, SaaI, SaaSk, SaaK, SaaT) (body parts)

$<$ PS *lejes $\leftarrow$ PScand *liduz / *lipuz > ON liðr 'member; joint'.

The North Saami word ladas 'joint' has been borrowed from a Proto-Germanic word from which the Proto-Scandinavian and Old Norse forms have been developed (Aikio 2006: 15).

lijnie 'shawl, scarf' (SaaS, SaaU, SaaP, SaaL, SaaN, SaaI, SaaSk, SaaK, SaaT) (clothing) $<$ PS $*$ lijnē $\leftarrow$ PScand *lina $>$ ON lín 'linen'.

In $\mathrm{ON}$ the meaning of the word is the fabric of which shawls and scarves are often made. The semantic shift in SaaS into the actual products made of linen is quite logical. The word is secondarily categorized under agriculture and animal husbandry. 


\section{Minerva Piha}

liksie, livsie, lievsie, luevsie 'blubber oil; lamp, light' (SaaS, SaaL, SaaN, SaaSk) (workrelated words)

$(<\mathrm{PS}) \leftarrow$ PScand ${ }^{\star}$ leuhsa- $>$ ON ljós 'valo'.

The word has been borrowed separately into SaaS (Aikio 2009: 260). The semantics of the etymology are transparent.

loeves 'loose' (SaaS, SaaU, SaaP, SaaL, SaaN, SaaI, SaaSk, SaaK, SaaT) (adjectives)

$<$ PS *lōves / *luovōs luoves 'free, loose' $\leftarrow$ PScand *laus- > ON lauss; Sw lös; N løs 'loose'.

luptedh 'to lift' (SaaS, SaaP, SaaL, SaaN, SaaI, SaaSk, SaaK, SaaT) (action processes)

$<$ PS *lopteje- $/{ }^{*}$ lopte 'to ascend' $\leftarrow$ PScand ${ }^{*}$ loftja- / *luftja > Sw lyfta 'to lift'.

maake 'man married to one's aunt (mother's or father's side)' (SaaS, SaaU, SaaP, SaaL, SaaN, SaaI, SaaSk, SaaK) (humans and humans as members of society)

$<\mathrm{PS}{ }^{\star}$ māke 'brother-in-law'

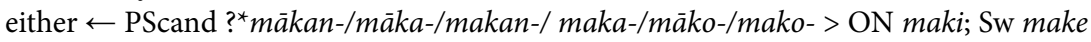
'husband'.

or $\leftarrow$ PScand ${ }^{*} m \bar{a} g a>$ On mágr 'a male relative by marriage; son-in-law, father-in-law or brother-in-law'; Sw måg 'son-in-law'

The semantic shift from husband to a man who is married to one's aunt is understandable as the Saami women who married Scandinavian men may have referred to their husbands using the Scandinavian word. The Saami society borrowed the word and began to use it to refer to a certain (more distant) relative. It must be noted that marriages between Saami women and Scandinavian men must have already been common during the Early Iron Age as the contacts have affected the vocabulary referring to family and relatives (see also provrese). Sammallahti (1998: 129) has determined the word to be of PScand origin but no reconstruction has been made. From the SaaS perspective, the PScand form could be one of the following: * mäkan-/māka-/makan-/ maka-/mäko-/mako-.

The other suggestion for the etymology of the word ( $<$ PScand $\left.{ }^{\star} m a \bar{g} a\right)$, made by Schalin (2018 pers. comm.) is, in fact, even more flawless and convincing from the perspective of the phonetics and semantics of the words.

maanoe 'month' (SaaS, SaaU, SaaP, SaaL, SaaN, SaaI, SaaSk, SaaK, SaaT) (relations in time and space)

< PS *mānō 'moon' $\leftarrow$ Pscand *mānan- / *mānōn- > ON máni, mána- 'moon'.

The Scandinavian word has shifted to refer to a month as SaaS has another word for moon: aske. An etymology for aske has not been proposed. In some Saami languages, e.g. SaaN, the Scandinavian loanword has the meaning of moon.

maarhvie 'rectum, rump, backside' (SaaL, SaaN, SaaI, SaaSk) (body parts) $(<\mathrm{PS}) \leftarrow \mathrm{NwS}{ }^{*}$ märfē $>$ PScand * marhwa- $>\mathrm{ON}$ morr 'fat in the intestines'.

The word was borrowed into Saami, and the meaning has shifted. The original meaning referring to intestines is visible in SaaS, however, as the word has the meaning of the specific intestine, the rectum. In North Saami, márfi means 'sausage'. The sausage casing is often made of intestine. 


\section{Combining Proto-Scandinavian loanword strata in South Saami ...}

maelie 'animal blood; birch sap' (SaaS, SaaU, SaaP, SaaL, SaaN, SaaI, SaaSk, SaaK, SaaT) (food and cookery)

$<$ PS *mālēe 'sap' Ł PScand *māla- > ON mál 'meal'.

The word is a mix of Scandinavian the loan mål 'meal' and Finnish mahla 'sap' (Aikio 2009: 262-263). Animal blood refers here to blood that is used in a soup. In SaaN, SaaI and SaaSk, the meaning of the word is soup. Because of the meaning of 'birch sap', the secondary category for the SaaS word is flora.

naehpie 'milking bowl for milking reindeer' (SaaS, SaaU, SaaP, SaaL, SaaN, SaaI, SaaSk, SaaK, SaaT) (reindeer and reindeer husbandry)

$<$ PS *nāppe 'bowl' $\leftarrow$ PScand *hnappaz > ON hnappr 'bowl'; N napp.

nejpie 'knife' (SaaS, SaaU, SaaP, SaaL, SaaN, SaaI, SaaSk, SaaK, SaaT) (work-related words)

$<$ PS ${ }^{\star} n e j B \bar{e}<{ }^{\star} n e j p \bar{a} \leftarrow$ ?Paleo-Germanic ${ }^{\star} k n e i b a>$ ON knifr; Sw, N kniv.

According to Heikkilä (2014: 112 footnote 97), the word is an earlier, separate loan in SaaS as the vowel in the first syllable is irregular from the point of view of the other Saami languages. The etymology for the forms in other Saami languages is: < PS ${ }^{\star}$ nijpe $<$ PScand ${ }^{*} k n \bar{b} b a>$ ON knifr; S, N kniv 'knife'. The Paleo-Germanic reconstruction for the word is ${ }^{\star} k n e i b a-$, but it is hardly possible for the SaaS word to be derived from there.

noerhte 'north' (SaaS, SaaU, SaaP, SaaL, SaaN, SaaI, SaaSk, SaaK, SaaT) (relations in time and space)

$<$ PS *nōrttē 'north, east, south' $\leftarrow$ PScand * norpr- > ON norðr; Sw, N nord 'north'.

From SaaN; towards east, the word can also refer to 'east'.

nuehtie 'seine net' (SaaS, SaaU, SaaP, SaaL, SaaN, SaaI, SaaSk, SaaK, SaaT) (hunting and fishing)

$<\mathrm{PS}{ }^{\star} n o \bar{t} t \bar{e} /{ }^{\star}$ nuottē 'seine net' $\leftarrow$ PScand ${ }^{\star}$ nōt- / ${ }^{\star}$ nōtu $>$ Sw not 'seine net'.

plaahkoe 'low flat terrain' (SaaS; SaaU, SaaL, SaaN) (terrain and landscape)

$<$ PS ${ }^{\star}$ pläkkō $\leftarrow$ PScand ${ }^{\star}$ flahu $>$ ON fló 'rock ledge; gently sloping valley up in the mountains'.

The word has been borrowed separately into Southern Proto-Saami, as the PS form in the other languages would be ${ }^{*} l a \bar{k} \bar{o}$. The semantics of the etymology is quite transparent, as both the SaaS and ON words refer to flat terrain in comparison with mountains and hills.

plaassa 'large rock that sticks out of ground or up from water'. (SaaS, SaaL, SaaN, SaaI, SaaSk) (terrain and landscape)

$<$ PS ${ }^{\star}$ plāssā $\leftarrow$ PScand ${ }^{\star}$ flasja / ${ }^{\star}$ flasjō > ON fles 'flat rock'.

The word has been borrowed separately into SaaS. In the other Saami languages, e.g. SaaN lás'sá, the word stems from PS *lāssāa. (Aikio 2012: 77, 111.) The semantics of the etymology is transparent. The meaning has shifted from a flat rock to large rock and then become more specified to mean a certain kind of rock. 


\section{Minerva Piha}

plaerie 'leaf of a plant, book; blade of a knife; (news)paper;' (SaaU, SaaP, SaaL, SaaN, SaaI) (flora)

$(<$ PS $) \leftarrow$ PScand *blad $(a)->$ ON blað 'leaf of a plant; herb'.

'Leaf of a plant' is the oldest meaning of the word. The word could also belong to the category of work-related words.

plievvies 'shy; despicable' (SaaS) (adjectives)

$<$ PS ${ }^{\star}$ plievvēs $\longleftarrow$ PScand ${ }^{\star}$ bleugaz $>$ ON bljúgr 'bashful, shy'.

The semantics is clear, but it should be noted that the SaaS word has acquired a somewhat negative connotation.

provrese 'bride' (SaaS, SaaU, SaaP, SaaN) (humans and humans as members of society) $<$ PS ${ }^{\star}$ pruvdës $\leftarrow$ PScand *brūdiz > ON brúðr, Sw brud 'bride.'

The word has been borrowed separately into the southern Saami languages (South, Ume and Pite Saami). The North Saami word ruvddas derives from the Proto-Saami form

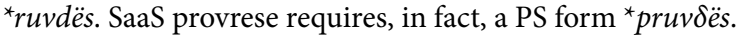

raajne 'clean' (SaaS, SaaU, SaaP, SaaL, SaaN, SaaI) (adjectives)

$<$ PS ?*räjne $\leftarrow$ PScand *hrainiz > ON hreinn 'clear; blank'.

raajroe 'reindeer caravan; series' (SaaS, SaaI, SaaK, SaaSk, SaaL, SaaP, SaaN, SaaT, SaaU) (reindeer and reindeer husbandry)

$<$ PS *rājōo / ${ }^{*}$ rājtō $\leftarrow$ PScand *raiđō > ON reið 'riding; cart'; Sw rida 'to ride'.

The etymology is semantically flawless, as both the Saami and the Scandinavian words refer to travelling. In Saami, the meaning has shifted to mean the way of travelling that was more common for the Saami people. The word could also be classified under vehicles and travelling.

raaktse 'tow rope (for a sled)' (SaaS, SaaU, SaaP) (vehicles and travelling) $(<\mathrm{PS}) \leftarrow$ PScand ${ }^{\star}$ drahtuz $>$ ON dráttr 'drag, pull, tug; journey, voyage’.

The ON word has two meanings: on one hand, the word refers to pulling and on the other to journeying. It is possible that the SaaS meaning is a mix of these two meanings: the tow rope is a contraction of the pulling and the sled is meant for travelling.

raammaa 'frame (of a picture)' (SaaS, SaaP, SaaL, SaaN, SaaI, SaaSk, SaaK, SaaT) (buildings and constructions)

$<$ PS * remes $\leftarrow$ PScand ${ }^{\star}$ pramuz $>$ ON promr 'border, rim.'

raavke 'apparition, ghost' (SaaS, SaaS, SaaP, SaaL, SaaN, SaaSk, SaaK, SaaT) (religion and beliefs)

$<$ PS ${ }^{\star}$ rāvke 'sea ghost' $\leftarrow$ PScand ${ }^{\star}$ draugaz $>$ ON draugr 'ghost, spirit, dead inhabitant of a cairn'.

raavre 'red char' (SaaS, SaaU, SaaP, SaaL, SaaN, SaaI, SaaSk, SaaK, SaaT) (wild animals) $<\mathrm{PS}{ }^{*} r a \bar{v} \delta e \leftarrow$ PScand ${ }^{*}$ raudiō $>\mathrm{ON}$ reyðr; Sw röding 'char'. 


\section{Combining Proto-Scandinavian loanword strata in South Saami ...}

The word has been borrowed separately into SaaS. The other Saami languages require the PS form * rāvtō. (Aikio 2009: 272-273.) The semantics of the etymology is transparent.

raejvie '(predatory) bird nest on a tree' (SaaS) (wild animals)

$<$ PS ${ }^{\star} r a \bar{j} v \bar{e} \leftarrow$ PScand ${ }^{\star} h r a i w a>$ ON hroe 'corpse'; hroe-fugl 'predatory bird', hroe-dýr 'predator (animal)'.

riejries 'ready; ready to be on a journey' (SaaS, SaaL, SaaP) (adjectives)

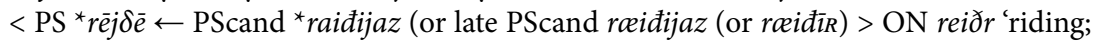
ready'.

PScand ${ }^{*}$ raidijaz is irregular from the PS perspective, as usually PScand first syllable ${ }^{*}-a$ - > PS $-\bar{a}$ - (Koivulehto 2002: 589 ). It is possible that the SaaS word was borrowed from late PScand ${ }^{\star}$ roeidijaz (or roidi $R$ ) (Schalin 2018 pers. comm.). If this holds true, the word should not be included in my data. As the late PScand ${ }^{*}$ - $x i$ - does not correspond regularly to SaaS $-i e-\left(<\right.$ PS $\left.{ }^{\star}-\bar{e}-\right)$, borrowing from late PScand is an uncertainty, and I have included the word in my data. The secondary category for the word is vehicles and travelling.

rïekte / rïektes 'correct; real, authentic' (SaaP, SaaL, SaaN, SaaI, SaaSk) (adjectives)

$(<\mathrm{PS}) \leftarrow$ PScand ${ }^{*}$ reht $-/^{*}$ rehtaz $>\mathrm{ON}$ réttr 'right'.

rijsie 'twig of birch' (SaaS, SaaU, SaaU, SaaP, SaaL, SaaN, SaaI, SaaSk, SaaK, SaaT) (flora) $<$ PS ${ }^{\star}$ rissēe 'twig' $\leftarrow$ PScand ${ }^{\star} h r i ̄ s a->$ ON hrís; Sw ris 'twig'.

There has been a contraction of the meaning in SaaS.

roehtse 'root of a tree or a plant' (SaaS, SaaU, SaaP, SaaL, SaaN, SaaI) (flora)

$<$ PS * rōcce $\leftarrow$ PScand * wrōtz / * wrōtiz > ON rót 'root'.

Koivulehto (1999b: 10) suggests that the PScand form is wrōtiz, but Schalin (2018, pers. comm.) notes that the form is ${ }^{*} w r o \bar{t} z$ without the vowel $-i$-. Schalin's remark constitutes a regular correspondence with the SaaS word.

råhtoe 'spruce forest; ?thicket of young deciduous trees; ?grove' (SaaS, SaaU, SaaP, SaaL, SaaN, SaaI, SaaSk, SaaK) (flora)

$<$ PS ${ }^{\star}$ rotō 'thicket of young deciduous trees; grove' $\leftarrow$ PScand ${ }^{\star}$ brutan- $>$ ON broti 'heap of trees felled in a wood'.

The semantics of the etymology is transparent. The secondary semantic category for the word is terrain and landscape. It should be noted that the word råhtoe has likely been borrowed earlier than e.g. provrese as the initial consonant cluster pr-cannot be seen in SaaS.

råtnoe 'reindeer doe' (SaaS, SaaU, SaaP, SaaL, SaaN, SaaI, SaaSk, SaaK, SaaT) (reindeer and reindeer husbandry)

$<$ PS ${ }^{\star}$ ronō 'reindeer doe' $\leftarrow$ PScand ${ }^{*}$ runō $>$ ON runi 'wild boar; boar'.

Semantically, the etymology is complicated. It is difficult to determine why a word that in Scandinavian refers to a (male) wild boar has shifted to mean a female reindeer in 


\section{Minerva Piha}

Saami. Aikio (2009: 274) notes that the Saami word has possibly been borrowed from a hypothetical, feminine form of PScand ${ }^{*}$ runan-, so this might explain the shift to referring to a female animal. One hypothesis is that similarities in behavior have caused the semantic shift: female reindeer are aggressively protective of their offspring and their behavior could be offensive like that of boars'. Also, the noise of a reindeer and a wild boar (or swine in general) are similar, and they are both artiodactyl animals. ${ }^{27}$

saajve 'a mythical creature thought to live inside mountains' (SaaS, SaaP, SaaL, SaaN, SaaI, SaaSk, SaaK, SaaT) (religion and beliefs)

$<$ PS *sājve / *sāvje 'fresh water; mythical creature who was thought to live underground' $\leftarrow$ PScand ${ }^{*}$ saiwi- / ${ }^{*}$ saiw- > ON saer $\sim$ sjár $\sim$ sjór 'lake'.

In the other Saami languages, the meaning of the word is connected with water, for example SaaL sájvva 'sacred lake; sacred mountain'. The semantic development in SaaS might have been as follows: lake $>$ sacred lake $>$ sacred mountain (if the mountains became more important in the religion at some point and the word shifted or expanded to mountains) $>$ a mythical creature living inside mountains.

saalje 'goat willow, great sallow' (SaaS, SaaU, SaaP, SaaL, SaaP, SaaSk) (flora)

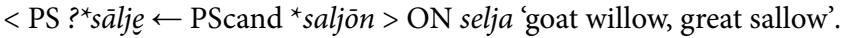

saavtje, saavhtse 'sheep' (SaaS, SaaU, SaaP, SaaL, SaaN, SaaI, SaaSk) (agriculture and animal husbandry)

$<$ PS *sāvce 'sheep' $\leftarrow$ PScand ${ }^{\star}$ saudiz > ON sauðr; N saud, sau 'sheep'.

saedtie 'sand' (SaaS, SaaU, SaaP, SaaL, SaaN, SaaI) (terrain and landscape)

$<\mathrm{PS}$ ?*sānte $\leftarrow$ PScand ${ }^{\star}$ sandaz 'sand' > ON sandr; Sw sand 'sand'.

saejrie 'wound, cut; sore' (SaaS, SaaU, SaaP, SaaL, SaaN, SaaI) (body parts)

$<$ PS ?*sārjēe $\leftarrow$ PScand ${ }^{*}$ sairaz $>$ ON sár, sárr 'wound, cut, sore’.

saejrie, saejtie 'coalfish' (SaaS, SaaU, SaaP, SaaL, SaaN, SaaI, SaaSk, SaaK, SaaT) (wild animals)

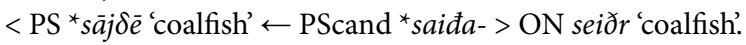

sïlpe 'silver' (SaaS, SaaU, SaaP, SaaL, SaaN, SaaI, SaaSk, SaaK, SaaT) (work-related words) $<$ PS * silpe $\leftarrow$ PScand ${ }^{\star}$ silbra- > ON silfr 'silver'; Sw silver; N sølv.

skaaltjoe 'seashell' (SaaU, SaaL, SaaN, SaaI, SaaS, SaaSk, SaaK) (wild animals)

$<\mathrm{NwS}{ }^{\star}$ skälćō $\leftarrow$ PScand ${ }^{\star}$ skaljō- > ON skel 'shell'.

skaavtjoe 'beard' (SaaS, SaaU, SaaP, SaaL, SaaN) (body parts)

$<\mathrm{PS}{ }^{\star}$ skāvča $\leftarrow$ PScand ${ }^{*}$ skagja $>\mathrm{ON}$ skegg 'beard'.

skugkie 'shadow; silhouette' (SaaS, SaaL, SaaN) (natural phenomena)

$(<\mathrm{PS}) \leftarrow$ Pscand ${ }^{*}$ skuggwan $>$ ON skuggi 'shadow; specter'.

Aikio (2012: 110) has discussed the SaaL word skovve and has reconstructed its 
origins as $<$ PS ${ }^{\star}$ skove $<$ Pre-Pscand ${ }^{\star}$ skuwwan $>$ Pscand ${ }^{\star}$ skuggwan. It is probable that the SaaS form stems from Proto-Scandinavian ${ }^{\star}$ skuggwan, as there is $-g k$ - in the SaaS form. Accordingly, the PS form * skove is irregular from the point of view of the SaaS word. The semantics of the etymology is quite straightforward.

skuvmie 'freight cover; tarp' (SaaS, SaaN, SaaI) (vehicles and travelling) $<$ PS *skuma- $\leftarrow$ PScand *skūma- > N skum 'foam'.

Sköld $(1986,136)$, gives the PS form as ${ }^{\star}$ sküma-, but as there is no long vowel ${ }^{\star} \bar{u}$ in PS, J. Häkkinen (2017 pers. comm.) deems the PS form ${ }^{*}$ skuma- to be correct. Koivulehto (1992a: 93) explains that foam is a covering on a liquid and therefore the semantic development into 'freight cover; tarp' is clear. In SaaN, the meaning is 'woman's outer cap' It too has a covering role though it is not as visible as the meaning in SaaS. The etymology is considered reliable, though Koivulehto (1992a: 93) is not certain about the dating: it could also be a NwG loan.

slikte 'smooth and flat' (SaaS; SaaN) (adjectives)

$<$ PS ${ }^{\star}$ sliktë $\leftarrow$ PScand ${ }^{\star}$ slihtaz > ON sléttr 'flat, smooth, even'

The word has been borrowed separately into Southern Proto-Saami (Aikio 2012: 110). The North Saami word stems from *liktēs. The semantics of the word is transparent.

snaejrie 'slice (of bread, cheese)' (SaaS, SaaL, SaaN, SaaI, SaaSk) (food and cookery) $(<\mathrm{PS}) \leftarrow$ PScand ${ }^{\star}$ snaipō $>$ ON sneið 'cut, split'.

staavra 'pole; fishing rod' (SaaS, SaaP, SaaL, SaaN, SaaI) (hunting and fishing) $<$ PS ? $^{\star}$ stāvre $\leftarrow$ PScand ${ }^{*}$ stauraz $>$ ON staurr 'pole'. Another possible semantic category for the word is tools and working materials.

staeries 'certain; trustworthy' (SaaS, SaaL, SaaN) (adjectives)

$(<\mathrm{PS}) \leftarrow$ PScand ${ }^{*}$ stadaz $>$ ON staðr 'vakaa'.

ståapoe 'house, hut, cottage' (SaaS, SaaU, SaaP, SaaL, SaaN) (buildings and constructions)

$(<\mathrm{PS}) \leftarrow$ PScand ${ }^{\star}$ stubōn $>$ ON stofa 'house, hut, cottage'; N stuva.

suahtehke 'delicious, sweet (food)' (SaaS, SaaP, SaaL, SaaN, SaaI, SaaSk) (food and cookery)

$<$ PS * sōtte / ${ }^{*}$ suotte 'pleasant; sweet (food)' $\leftarrow$ PScand * swōti- > Sw söt 'sweet'.

sudtie 'opening in ice' (SaaS, SaaU, SaaP, SaaL, SaaN, SaaI, SaaSk, SaaK, SaaT) (water and water systems)

$<$ PS ${ }^{\star}$ suntē 'ice hole; smelt' $\leftarrow$ PScand ${ }^{*}$ sunda $>\mathrm{N}$, Sw sund 'strait'.

The etymology is uncertain as, according to Aikio (2009: 153), the semantic development is complex: 'strait' > 'place with a strong current' > 'place which remains unfrozen due to a strong current' > 'opening in ice' ( $>$ 'unfrozen'). The alternative etymology points to Finnish as the donor language (< Finnish suntan 'thaw') (Sammallahti 1998: 264). 


\section{Minerva Piha}

svaajnes 'farm worker; big, strong, fat reindeer; quick (of a person)' (SaaS, SaaU, SaaP, SaaL) (agriculture and animal husbandry)

$<$ PS ?*svājne $\leftarrow$ PScand *swainaz > ON sveinn 'boy, lad, young male; servant'.

The word could be classified in the category of humans and humans as members of society or reindeer and reindeer husbandry.

svaaloe 'swallow (bird)' (SaaS, SaaU, SaaP, SaaL, SaaN, SaaI, SaaSk) (wild animals)

$<$ PS ${ }^{\star}$ svālfō $\leftarrow$ PScand ${ }^{*}$ swalwōn- (?*swalhwōn-) $>$ ON svala 'swallow'.

svijnie 'swine' (SaaS, SaaU, SaaP, SaaL, SaaN) (agriculture and animal husbandry)

$<\mathrm{PS}{ }^{\star}$ svijnē $\leftarrow$ PScand ${ }^{\star}$ swina $>\mathrm{ON}$ svín; Sw, N svin 'swine'.

täjhkoe 'female dog' (SaaS, SaaL, SaaN, SaaI, SaaSk, SaaK) (agriculture and animal husbandry)

$<$ PS ${ }^{\star} t i j k k \bar{o} \leftarrow$ PScand ${ }^{\star} t \bar{k} k \bar{o} /{ }^{\star} t \bar{i} k u>$ ON $t i ́ k$ 'female dog'.

vaanhtse, faahtse 'mitten' (SaaS, SaaU, SaaP, SaaL, SaaN, SaaI, SaaSk, SaaK, SaaT) (clothing)

$<$ PS *vācce 'mitten' $\leftarrow$ PScand *wantuz > ON vottr; Old Sw vanter; Sw vante 'mitten'.

The PS form * vācce is not fit for SaaS, as there is a nasal in the SaaS word. A better form might be ${ }^{\star}$ vancce. This might be a separate loan in SaaS unless the SaaS form gained the nasal again later. The word is secondarily categorized under agriculture and animal husbandry.

vaarese 'homespun fabric' (SaaS, SaaU, SaaP, SaaL, SaaN) (clothing)

$(<\mathrm{PS}) \leftarrow$ PScand ${ }^{*}$ wä diz $>$ ON váð 'piece of cloth, garment'.

There has been an expansion of the meaning. The original word likely referred to a garment that was made of homespun fabric. In SaaS, the meaning has been expanded to refer to all (homespun) fabric. The SaaS word for clothes has been borrowed from the same PScand word (see vaarjoeh, vaarjese). The word is secondarily categorized under agriculture and animal husbandry.

vaarjoeh, vaarjese 'clothes; fabric' (SaaS, SaaU, SaaP, ?SaaL, SaaN, SaaI, SaaSk, SaaK, SaaT) (clothing)

$<$ PS *vārjñ 'cloth, piece of clothing' $\leftarrow$ PScand ${ }^{*} w a \overline{d i z}>\mathrm{ON}$ vád 'piece of cloth, garment'.

The word is secondarily classified under agriculture and animal husbandry.

vaartasjidh 'to look closely, examine, follow with eyes' (SaaS, SaaU, SaaP, SaaL, SaaN, SaaI, SaaSk, SaaT) (action processes)

$<$ PS *vārtāšse- / *vārtā 'examine' $\leftarrow$ PScand *warđō- > ON varða 'to guard, watch, defend'.

The semantics of the etymology is quite clear as the meaning has to do with sight both in Saami and in Old Norwegian. 


\section{Combining Proto-Scandinavian loanword strata in South Saami ...}

vaegkie 'broad valley, low terrain where grass grows' (SaaS, SaaL, SaaP, SaaN) (terrain and landscape)

$<$ PS *vāykē $\leftarrow$ PScand *wangaz $>$ ON vangr 'field, meadow'.

vaeltedh 'to take' (SaaS, SaaU, SaaP, SaaL, SaaN, SaaI, SaaSk, SaaK, SaaT) (action processes)

$<$ PS *vāltē $\leftarrow$ PScand ${ }^{\star}$ walda- / *waldan > ON valda; Sw våld 'violence, force'.

The development of the meaning is an expansion from a more specific meaning of 'to take by violence' to the general meaning of taking.

vaenie(s) 'scanty, scarce; a small amount' (SaaS, SaaU, SaaP, SaaL, SaaN, SaaI, SaaSk, SaaK, SaaT) (adjectives)

$<$ PS *vānē (-s)'scarce' $\leftarrow$ PScand *vanaz > ON vanr 'lacking, wanting'.

veapsa 'wasp' (SaaS, SaaU, SaaP, SaaL, SaaN, SaaI, SaaSk, SaaK, SaaT) (wild animals)

$<$ PS *vēpsēs 'wasp' $\leftarrow$ PScand *hwepsaz > ON, N hvefs; Sw dial. väfse; N veps 'wasp'.

vïerhtse 'ram' (SaaS, SaaU, SaaP, SaaL, SaaN, SaaI, SaaSk, SaaK) (agriculture and animal husbandry)

< PS *vērcce 'ram' $\leftarrow \mathrm{NwG}^{*}$ wépru- > PScand *wepruz > ON veðr; N ver 'ram'.

vijries 'wide, vast' (SaaS, SaaU, SaaP, SaaL, SaaN, SaaI, SaaSk) (adjectives)

$<$ PS * vijoēs 'wide' $\leftarrow$ PScand *wīaz $>$ Sw vid 'wide, vast'.

voevnijes 'terrible, grim' (SaaS, SaaL, SaaN, SaaI) (adjectives)

$(<\mathrm{PS}) \leftarrow$ PScand ${ }^{*} \overline{o g n i}$ - > ON ógn 'awful, terrible'.

vuaksa 'ox' (SaaU, SaaP, SaaL, SaaN, SaaI) (agriculture and animal husbandry)

$<$ PS ${ }^{\star} \bar{o} k s \bar{a} \leftarrow$ PScand ${ }^{\star}$ oksan / ${ }^{\star} o k s \bar{e}$ 'ox'.

våhkoe 'week' (SaaS, SaaU, SaaP, SaaL, SaaN, SaaI) (relations in time and space) $(<\mathrm{PS}) \leftarrow$ Pscand *vika $>$ ON vika; Sw vecka 'week'. 


\section{Appendix 2. Reference literature for the lexical material}

\begin{tabular}{|c|c|}
\hline Saami word & Reference literature \\
\hline aajhtere & $\begin{array}{l}\text { Álgu s.v. aajtere; Collinder 1932, 193-196; Lagercrantz 1939, 27; } \\
\text { Sköld 1980, 108; Qvigstad 1893, 86; Koivulehto 1993b, } 129 .\end{array}$ \\
\hline aajloe & Koivulehto 2008, 321; 2016, 390. \\
\hline aajmoe & $\begin{array}{l}\text { Álgu s.v. aajmoe; Lagercrantz 1939, 26; Lehtiranta 1989, s.v. äjmō; } \\
\text { Qvigstad 1893, 83, 191; Sammallahti 1998, 128; 227; Sköld 196o, } \\
\text { 11-13. }\end{array}$ \\
\hline aajne & $\begin{array}{l}\text { Álgu s.v. áidnu; LÄGLOS } 1 \text { s.v. ainoa; Qvigstad 1893, 83-84; Sam- } \\
\text { mallahti 1998, 128; SSA } 1 \text { s.v. ainoa. }\end{array}$ \\
\hline aaksjoe & $\begin{array}{l}\text { Álgu s.v. ákšu; Bjorvand \& Lindeman } 2007 \text { s.v. } ø k s \text {; Lagercrantz } \\
\text { 1939, 29-30; Lehtiranta } 1989 \text { s.v. } \bar{a} k s ̌ n j n \text {; Schalin } 2018 \text { personal } \\
\text { comment 21.2.2018; Sammallahti 1998, } 128 \text {. }\end{array}$ \\
\hline aalhtedh & $\begin{array}{l}\text { Álgu s.v. elta; Koivulehto 1992a, 87; Qvigstad 1893, 89; ks.m. Ai- } \\
\text { kio 2012, } 79 \text {. }\end{array}$ \\
\hline aajroe & $\begin{array}{l}\text { Álgu s.v. áiru; Lagercrantz 1939, 27; Lehtiranta } 1989 \text { s.v. ājrō; } \\
\text { Qvigstad 1893, 86; SSA } 1 \text { s.v. airo. }\end{array}$ \\
\hline aarhtse & $\begin{array}{l}\text { Álgu s.v. aarhtse; Collinder 1932, 217; 1964, 52; Koivulehto 1999b, } \\
\text { 8; Lagercrantz 1939, 35-36; Qvigstad 1893, 91, } 93 \text {. }\end{array}$ \\
\hline aarjoehtidh & Álgu s.v. eira; LÄGLOS 1 s.v. aihella; Qvigstad 1893, 92. \\
\hline aarmoes & $\begin{array}{l}\text { Álgu s.v. armr; LÄGLOS } 1 \text { s.v. armas; Qvigstad 1893, 92; SSA } 1 \\
\text { s.v. armas. }\end{array}$ \\
\hline aartege, haartege & $\begin{array}{l}\text { Álgu s.v. hárdu; Kallio 2009, 37; Lagercrantz 1939, 157; Lehtiranta } \\
1989 \text { s.v. ārtijā; LÄGLOS 1, 84; Qvigstad 1893, 189; Sammallahti } \\
\text { 1998, 129; Schalin } 2018 \text { pers. comm.; SSA 1 s.v. hartia. }\end{array}$ \\
\hline aassjoe & $\begin{array}{l}\text { Algu s.v. áššu; Aikio 2006, 20; Lagercrantz 1939, 41; Sammallahti } \\
\text { 1998, } 128 .\end{array}$ \\
\hline aavtja & $\begin{array}{l}\text { Aikio 2006, 14; Álgu s.v. ávža; J. Häkkinen 2010b, 52; Koivulehto } \\
\text { 1991, 112; Qvigstad 1893, 98; Sköld 1960, 5-10. }\end{array}$ \\
\hline aavtjoe & $\begin{array}{l}\text { Álgu s.v. egg; Bergsland 1992, 7-8; Lagercrantz 1939, 42; Qvigstad } \\
\text { 1893, 97; SSA } 1 \text { s.v. aaja. }\end{array}$ \\
\hline aegnieh & Álgu s.v. agn; LÄGLOS 1 s.v. akana; Qvigstad 1893, 96. \\
\hline aejlege, aejlies & Bergsland 1992, 9; Lagercrantz 1939, 26 (152); Qvigstad 1893, 85. \\
\hline aepie & $\begin{array}{l}\text { Aikio } 2006,14 ; 2009,55,244 \text {; Álgu s.v. áhpi; Bjorvand \& Linde- } \\
\text { man } 2007 \text { s.v. hav; Koivulehto 1999b, 12, 13; 2008, 322; Lehtiranta } \\
1989 \text { s.v. āpē; Sammallahti 1998, } 128 \text {. }\end{array}$ \\
\hline
\end{tabular}


Combining Proto-Scandinavian loanword strata in South Saami ...

\begin{tabular}{|c|c|}
\hline Saami word & Reference literature \\
\hline$\grave{a r}{ }^{a H} k u_{\breve{u}}$ & $\begin{array}{l}\text { Álgu s.v. arkku; Lagercrantz 1939, 36; Qvigstad 1893, 92; SSA } 1 \\
\text { s.v. arkku. }\end{array}$ \\
\hline aerkie & $\begin{array}{l}\text { Álgu s.v. argr; Lagercrantz 1939, 36; Lehtiranta } 1989 \text { s.v. ārkē; LÄ- } \\
\text { GLOS } 1 \text { s.v. arka; Qvigstad 1893, 92; SSA } 1 \text { s.v. arki. }\end{array}$ \\
\hline aernie & $\begin{array}{l}\text { Álgu s.v. arina; Hasselbrink 1981, 217; Heikkilä 2014, 113; Lager- } \\
\text { crantz 1939, 37-38; LÄGLOS } 1 \text { s.v. arina; SSA } 1 \text { s.v. arina. }\end{array}$ \\
\hline aerpie & $\begin{array}{l}\text { Aikio 2006, 12, Álgu s.v. árbi; Bjurvand \& Lindeman 2007, s.v. } \\
\text { arv; Koivulehto 1976, 250; 2002, 587; Lagercrantz 1939, 37; Lehti- } \\
\text { ranta 1989, s.v. ārpēe, vōrpēe; Qvigstad 1893, 91; Sammallahti 1998, } \\
\text { 128; 1999, 83; 2001, 409. }\end{array}$ \\
\hline aevhkie & $\begin{array}{l}\text { Álgu s.v. ávki; Koivulehto 1976, 42; Lagercrantz 1939, 42; Qvig- } \\
\text { stad 1893, 97; Sammallahti 1998, 228; Schalin } 2018 \text { pers. comm. }\end{array}$ \\
\hline aevlerge & $\begin{array}{l}\text { Álgu s.v. ävli; Lehtiranta } 1989 \text { s.v. àvlē; LÄGLOS } 1 \text { s.v. haahla; } \\
\text { Qvigstad 1893, 97; SSA } 1 \text { s.v. haahla; ks.m. Aikio 2012, } 79 .\end{array}$ \\
\hline aevries & $\begin{array}{l}\text { Álgu s.v. audes; Collinder 1932, 221; Koivulehto 1976, 249; LÄG- } \\
\text { LOS } 1 \text { s.v. autio; Qvigstad 1893, 96; Sammallahti 1998, } 228 .\end{array}$ \\
\hline aevsie & $\begin{array}{l}\text { Álgu s.v. áksi; Bjorvand \& Lindeman } 2007 \text { s.v. haus; J. Häkkinen } \\
2017 \text { pers. comm.; Qvigstad 1893, 87; Sammallahti 1998, } 128 .\end{array}$ \\
\hline asspa & Álgu s.v. asp; LÄGLOS 1 s.v. haapa; Qvigstad 1893, 94. \\
\hline$a w c ̌ a$ & $\begin{array}{l}\text { Aikio 2006, 14; Álgu s.v. ávža; J. Häkkinen 2010b, 52; Koivulehto } \\
\text { 1991, 112; Qvigstad 1893, } 98 .\end{array}$ \\
\hline baante & $\begin{array}{l}\text { Álgu s.v. band; Israelsson } 2015 \text { s.v. baante; Lagercrantz 1939, 624; } \\
\text { LÄGLOS } 3 \text { s.v. panta; Qvigstad 1893, } 99 \text {. }\end{array}$ \\
\hline baarhkoe & Koivulehto 1987, 201; Lehtiranta 1989 s.v. pārkkn \\
\hline baaroe & $\begin{array}{l}\text { Aikio 2009, 268; Álgu s.v. baaroe; Lagercrantz 1939, 627; Lehti- } \\
\text { ranta } 1989 \text { s.v. pārō; Qvigstad 1893, } 102\end{array}$ \\
\hline baernie & $\begin{array}{l}\text { Aikio 2006, 18; Álgu s.v. bárdni; Korhonen 1981, 185; Lagercrantz } \\
\text { 1926, 111; 1939, 626-627; Lehtiranta } 1989 \text { s.v. pārnē; Qvigstad } \\
\text { 1893, 101; Sammallahti 1998, 128, } 230 .\end{array}$ \\
\hline bearkoe & $\begin{array}{l}\text { Aikio 2006, 14; Álgu s.v. biergu; Koivulehto 1988, 30; 1989, 45; } \\
\text { 2002; 589; 2016, 160; Lagercrantz 1939, 658; Lehtiranta 1989 s.v. } \\
\text { pērkō; Qvigstad 1893, 106; Sammallahti 1998, 128. } 231 .\end{array}$ \\
\hline betnie & $\begin{array}{l}\text { Álgu s.v. bodni; Bjorvand \& Lindeman } 2007 \text { s.v. botn; Lager- } \\
\text { crantz 1939, 605-606; Lehtiranta } 1989 \text { s.v. ponnē; Sammallahti } \\
1998,128 .\end{array}$ \\
\hline buvrie & $\begin{array}{l}\text { Aikio 2009, 270-271; Álgu s.v. buvrie; Koivulehto 1992a, 91; } \\
\text { 2002, 589; Lagercrantz 1926, 130; 1939, 687-688; Lehtiranta 1989 } \\
\text { s.v. puvrē; Qvigstad 1893, } 121\end{array}$ \\
\hline
\end{tabular}




\section{Minerva Piha}

\begin{tabular}{|c|c|}
\hline Saami word & Reference literature \\
\hline daajje & $\begin{array}{l}\text { Álgu s.v. deigr; Koivulehto 1976, 42; Lagercrantz 1939, 893; LÄG- } \\
\text { LOS } 3 \text { s.v. taikina; Qvigstad 1893, 124; SSA } 3 \text { s.v. taikina. }\end{array}$ \\
\hline daatje & $\begin{array}{l}\text { Aikio } 2009,281 \text {; Álgu s.v. daatje; Lagercrantz 1939, 904; Lehti- } \\
\text { ranta } 1989 \text { s.v. tānćę; Sammallahti 1998, 128, } 236 .\end{array}$ \\
\hline daerpies & $\begin{array}{l}\text { Aikio 2006, 22; Álgu s.v. dárbu; Heikkilä 2014, 46; Koivulehto } \\
\text { 2002, 586; Korhonen 1981, 91, 104, 194, 200; Lagercrantz 1939, } \\
\text { 910; Lehtiranta } 1989 \text { s.v. tārpẹ; Qvigstad 1893, 126; Sammallahti } \\
\text { 1998, 237; SSA } 3 \text { s.v. tarve. }\end{array}$ \\
\hline dahpe & $\begin{array}{l}\text { Aikio 2006, 24; Álgu s.v. dohppa; Koivulehto 1981, 77-78; 1987, } \\
\text { 195; Lagercrantz 1939, 897; Lehtiranta } 1989 \text { s.v. toppe; Sammal- } \\
\text { lahti 1998, 128; 1999, 82; 2001, 409; SSA } 3 \text { s.v. tuppi. }\end{array}$ \\
\hline davgh & $\begin{array}{l}\text { Álgu s.v. dávk; Koivulehto 1976, 43; Lagercrantz 1939, 902; Qvig- } \\
\text { stad 1893, 127; Sköld 1980, 108. }\end{array}$ \\
\hline deemedh & $\begin{array}{l}\text { Aikio 2009, 281; Álgu s.v. temja; Koivulehto 1992a, 87; Lager- } \\
\text { crantz 1939, 908-909; Lehtiranta } 1989 \text { s.v. tāme; Qvigstad 1893, } \\
123,125 .\end{array}$ \\
\hline ditnie & $\begin{array}{l}\text { Álgu s.v. datni; Lehtiranta } 1989 \text { s.v. tẹne; Nielsen } 1976 \text { s.v. tin; } \\
\text { Qvigstad 1893, 123; Sammallahti 1998, 128; Schalin } 2018 \text { pers. } \\
\text { comm. }\end{array}$ \\
\hline dovres, dovrehke & $\begin{array}{l}\text { Álgu s.v. dýrr; Bjorvand \& Lindeman } 2007 \text { s.v. dyri; Lagercrantz } \\
\text { 1939, 923; LÄGLOS } 3 \text { s.v. tyyris; Qvigstad 1893, 132; ks.m.SSA } 3 \\
\text { s.v. tyyris. }\end{array}$ \\
\hline dytnije & $\begin{array}{l}\text { Álgu s.v. didnu; Lagercrantz 1939, 896; Lehtiranta } 1989 \text { s.v. tinn } \overline{\text {; }} \\
\text { Qvigstad 1893, 129; Sammallahti 1998, } 128 .\end{array}$ \\
\hline dälja & $\begin{array}{l}\text { Álgu s.v. dilljá; Bergsland \& Mattson Magga } 2007 \text { s.v. doelja; } \\
\text { Bjorvand \& Lindeman } 2007 \text { s.v. tilje; Lagercrantz 1939, 914; 922; } \\
\text { Lehtiranta } 1989 \text { s.v. tiljā; Qvigstad 1893, 131, Sammallahti 1998, } \\
\text { 128; SSA } 3 \text { s.v. teljo. }\end{array}$ \\
\hline eajma & Aikio 2009, 183; Lagercrantz 1939, 116. \\
\hline eajmeske & Aikio $2009,183,184$ \\
\hline faala, faelies & $\begin{array}{l}\text { Aikio 2009, 286; 2012, 109; Álgu s.v. fális; Koivulehto 1999b, 11; } \\
\text { Lagercrantz 1939, 129; Lehtiranta } 1989 \text { s.v. vālās; Qvigstad 1893, } \\
\text { 144; Sammallahti 1998, 128; SSA 3 s.v. valas. }\end{array}$ \\
\hline faaroe & $\begin{array}{l}\text { Aikio 2006, 14; Álgu s.v. fárru; Korhonen 1981, 134; Lagercrantz } \\
\text { 1939, 131; 134; 135; Lehtiranta } 1989 \text { s.v. vārō; Qvigstad 1893, 146; } \\
\text { Sammallahti 1998, 128, } 241 .\end{array}$ \\
\hline faastoe & $\begin{array}{l}\text { Álgu s.v. faastoe; LÄGLOS } 3 \text { s.v paasto; Qvigstad 1893, 147, 158; } \\
\text { Schalin } 2018 \text { pers. comm. }\end{array}$ \\
\hline
\end{tabular}


Combining Proto-Scandinavian loanword strata in South Saami ...

\begin{tabular}{|c|c|}
\hline Saami word & Reference literature \\
\hline fealloe & $\begin{array}{l}\text { Aikio 2006, 14; 2012, 109; Álgu s.v. fiellu; Koivulehto 1976, 46; } \\
\text { 1988, 30; 1989, 45; 1992a, 92; 1992b, 301; 2002, 589; 2016, 160; La- } \\
\text { gercrantz 1939, 138; Qvigstad 1893, 150; Sammallahti 1998, } 128 \text {. }\end{array}$ \\
\hline fierve & $\begin{array}{l}\text { Aikio 2009, 246; 2012, 109; Álgu s.v. fierva; Koivulehto 1995, } 92 \mathrm{f} \\
\text { 7; Korhonen 1981, 134; Lagercrantz 1939, 141; Qvigstad 1893, } 151 .\end{array}$ \\
\hline fuelhkie & Álgu s.v. fuelhkie; Heikkilä 2014, 90; Schalin 2018, pers. comm. \\
\hline gaahkoe & $\begin{array}{l}\text { Álgu s.v. gáhkku; Bjorvand \& Lindeman } 2007 \text { s.v. kake; La- } \\
\text { gercrantz 1939, 260; Lehtiranta } 1989 \text { s.v. kākkñ; LÄGLOS } 2 \text { s.v. } \\
\text { kakku; Sammallahti 1998, 128; Schalin } 2018 \text { pers. comm.; ks.m. } \\
\text { Aikio 2012, 79. }\end{array}$ \\
\hline gaajedidh & Aikio 2009, 76; Álgu s.v. gaajedidh \\
\hline gaajhtse & $\begin{array}{l}\text { Aikio 2009, 106, 250; Álgu s.v. gáica; Bjorvand \& Lindeman } \\
2007 \text { s.v. geit; Koivulehto 1999b, 10; 2002, 589; Lagercrantz 1939, } \\
\text { 84, 256-257; Qvigstad 1893, 159-160; Sammallahti 1998, } 128\end{array}$ \\
\hline gaaltije & $\begin{array}{l}\text { Aikio 2009, 250; Álgu s.v. gáldu; Koivulehto 2008, 322; 2016, 391; } \\
\text { Lagercrantz 1939, 263; Lehtiranta } 1989 \text { s.v. kāltijä; Qvigstad 1893, } \\
\text { 160; Sammallahti 1998, 128; 2012, 100. }\end{array}$ \\
\hline gaavnedh & $\begin{array}{l}\text { Álgu s.v. gagn; Koivulehto 1992a, 87-88; 2002, 589; Lagercrantz } \\
\text { 1939, 274-275; Lehtiranta } 1989 \text { s.v. kāvnę; Sammallahti 1998, } 243 .\end{array}$ \\
\hline gaavnoe & $\begin{array}{l}\text { Álgu s.v. gávdni, gagn; Koivulehto 2002, 589; Lagercrantz 1939, } \\
\text { 274; Lehtiranta } 1989 \text { s.v. kāvnē; Qvigstad 1893, 167; Sammallahti } \\
\text { 1998, 129, } 243 .\end{array}$ \\
\hline gaejmie & Aikio 2009, 249; Lagercrantz 1939, 258. \\
\hline gaejsie & $\begin{array}{l}\text { Álgu s.v. gáisi; Aikio 2009, 249; Heikkilä 2011, 69; 2014, 121; } \\
\text { LÄGLOS } 2 \text { s.v. kaira, keihäs; Nordic Languages 2002, 117; Sköld } \\
1954,35 .\end{array}$ \\
\hline gaellies & $\begin{array}{l}\text { Aikio 2009, 250; Ảlgu s.v. gállis; Koivulehto 1999b, 11; Lager- } \\
\text { crantz 1939, 261-262; Lehtiranta } 1989 \text { s.v. kâlless, Qvigstad 1893, } \\
\text { 161-162; Sammallahti 1998, } 128 .\end{array}$ \\
\hline gaelpie & $\begin{array}{l}\text { Álgu s.v. kalfr; Heikkilä 2014, 240; Lagercrantz 1939, 263; LÄG- } \\
\text { LOS } 2 \text { s.v. kalpe; Qvigstad 1893, 160; ks.m. Aikio 2012, 79. }\end{array}$ \\
\hline gaerie & $\begin{array}{l}\text { Aikio } 2009,248 \text {; Álgu s.v. gárri; Lagercrantz 1939, 269; Lehti- } \\
\text { ranta } 1989 \text { s.v. kārē; Qvigstad 1893, 165; Sammallahti 1998, 129; } \\
\text { SSA } 1 \text { kaara. }\end{array}$ \\
\hline gaertie & $\begin{array}{l}\text { Aikio 2009, 249; Álgu s.v. gárdi; Koivulehto 2002, 589; Lehti- } \\
\text { ranta } 1989 \text { s.v. kārtē; Qvidstad 1893, 164-165; Sammallahti 1998, } \\
\text { 129; SSA } 1 \text { s.v. kaarre2. }\end{array}$ \\
\hline
\end{tabular}




\section{Minerva Piha}

\begin{tabular}{|c|c|}
\hline Saami word & Reference literature \\
\hline gaessie & $\begin{array}{l}\text { Koivulehto 1999b, 14; Lagercrantz 1939, 272; Lehtiranta } 1989 \text { s.v. } \\
\text { kāssē; Qvigstad 1893, 166; Schalin } 2018 \text { pers. comm. }\end{array}$ \\
\hline gealoe & Álgu s.v. gealoe; Koivulehto 1992a, 91; Sammallahti 1998, 128. \\
\hline gearhka & Álgu s.v. geärkaa; Koivulehto 1992a, 92; 1992b, 301; 2016, 175. \\
\hline geehtedh & Koivulehto 1999a, 258; Lagercrantz 1939, 273; Qvigstad 1893, 166. \\
\hline giëhtjedh & $\begin{array}{l}\text { Álgu s.v. giëhtjedh; Heikkilä 2014, 80; J. Häkkinen } 2017 \text { pers. } \\
\text { comm.; Lagercrantz 1939, 278; Lehtiranta } 1989 \text { s.v. kēććé; Sam- } \\
\text { mallahti 2001, } 399 \text {. }\end{array}$ \\
\hline gïeles & $\begin{array}{l}\text { Aikio 2009, 252; Álgu s.v. gielas; Lagercrantz 1939, 304; Qvigstad } \\
\text { 1893, } 168 .\end{array}$ \\
\hline $\begin{array}{l}\text { goeme, guemie, } \\
\text { gåemie }\end{array}$ & $\begin{array}{l}\text { Álgu s.v. guopmi; Bjorvand \& Lindeman } 2007 \text { s.v. gomme; Lager- } \\
\text { crantz 1926, 59; 1939, 371; Qvigstad 1893, 183; Sammallahti 1998, } \\
128 .\end{array}$ \\
\hline govse & $\begin{array}{l}\text { Álgu s.v. gussa; Heikkilä 2014, 240; Koivulehto 1990, 37; 1992a, } \\
\text { 91; 1999b, 14f 2; 2002, 589; Korhonen 1981, 47, 202; Lagercrantz } \\
\text { 1939, 357, 360; Lehtiranta } 1989 \text { s.v. kuse; Qvigstad 1893, 184; Sam- } \\
\text { mallahti 1998, 129. }\end{array}$ \\
\hline haajhke & $\begin{array}{l}\text { Aikio 2009, 245; Álgu s.v. haajhke; Koivulehto 2006, 424; Lager- } \\
\text { crantz 1939, 150; Lehtiranta } 1989 \text { s.v. ājkke; Lagercrantz } 1926 \text { s.v. } \\
\text { hą í } \chi \chi \xi \text {; Qvigstad 1893, 84; Sammallahti 1998, 129; SSA 1 s.v. aihki. }\end{array}$ \\
\hline haallode & $\begin{array}{l}\text { Álgu s.v. álu-; Lagercrantz 1939, 153-154; Lehtiranta } 1989 \text { s.v. ālñ; } \\
\text { LÄGLOS } 1 \text { s.v. kallas; Qvigstad 1893, 188; Sammallahti 1998, } 128 .\end{array}$ \\
\hline haame & Koivulehto 2008, 323; 2016, 392. \\
\hline haelmie & $\begin{array}{l}\text { Álgu s.v. halmr; Lagercrantz 1939, 147; LÄGLOS } 1 \text { s.v. halme; } \\
\text { Qvigstad 1893, } 188 .\end{array}$ \\
\hline haepkie & $\begin{array}{l}\text { Álgu s.v. haukr; Lagercrantz 1939, 156; LÄGLOS } 1 \text { s.v. haukka1; } \\
\text { Qvigstad 1893, 186-187. }\end{array}$ \\
\hline hiessjie & $\begin{array}{l}\text { Álgu s.v. asso; Koivulehto 1999b, 14; Qvigstad 1893, 94; Schalin } \\
2018 \text { pers. comm. }\end{array}$ \\
\hline hovme & Aikio 2009, 173-174; Lagercrantz 1939, 178. \\
\hline ibje & Aikio 2006, 25; Álgu s.v. ïbje; Qvigstad 1893, 338. \\
\hline klaajpoe & $\begin{array}{l}\text { Álgu s.v. klaajpoe; Lagercrantz 1939, 312; Schalin 2018, pers. } \\
\text { comm.; Sköld 1960, 16, } 17 \text {. }\end{array}$ \\
\hline klahtje & $\begin{array}{l}\text { Aikio 2012, 110; Álgu s.v. kleggi; Lagercrantz 1939, 312; Qvigstad } \\
\text { 1893, } 214 .\end{array}$ \\
\hline kraavhtse & $\begin{array}{l}\text { Aikio 2009, 272; 2012, 110; Álgu s.v. rákca; Koivulehto 1999b, 7; } \\
\text { Korhonen 1981, 182; Lagercrantz 1939, 344, 385-386, 716; Qvig- } \\
\text { stad 1893, } 179 .\end{array}$ \\
\hline
\end{tabular}




\begin{tabular}{|c|c|}
\hline Saami word & Reference literature \\
\hline kraesie & $\begin{array}{l}\text { Aikio 2012, 110; Álgu s.v. rássi; Heikkilä 2011, 78; Koivulehto } \\
\text { 1999b, 14f 2; Lagercrantz 1939, 386-387; Lehtiranta } 1989 \text { s.v. rāsē; } \\
\text { Qvigstad 1893, 259; Sammallahti 1998, } 129 .\end{array}$ \\
\hline kraevies & $\begin{array}{l}\text { Aikio 2012, 110; Álgu s.v. grár; Bergsland 1992, 10; Lagercrantz } \\
\text { 1939, 387; Qvigstad 1893, 260-261. }\end{array}$ \\
\hline krievvie & Aikio 2012, 110; Álgu s.v. krievvie; Bergsland 1988, 161-162. \\
\hline $\begin{array}{l}\text { kruana / } \\
\text { kråånehke }\end{array}$ & $\begin{array}{l}\text { Álgu s.v. kråånehke; Koivulehto 1988, 36; 1999b, 17; Lagercrantz } \\
\text { 1926, 68; 1939, 391; Lehtiranta } 1989 \text { s.v. rōnę; Qvigstad 1893, } 275 .\end{array}$ \\
\hline laaffa & $\begin{array}{l}\text { Aikio 2006, 14; 2012, 109; Álgu s.v. lávkkis; Lagercrantz 1939, 402; } \\
\text { Qvigstad 1893, 211; Sköld 1980, } 108 .\end{array}$ \\
\hline laajkoe & $\begin{array}{l}\text { Aikio 2009, 260; Algu s.v. láigu; Koivulehto 1999a, 49; 2002, 589; } \\
\text { Lagercrantz 1926, 70; 1939, 402-403; Qvigstad 1893, 208; Sam- } \\
\text { mallahti 1998, 128; 2012, 100; SSA 2 s.v. laikko1. }\end{array}$ \\
\hline laajroe & 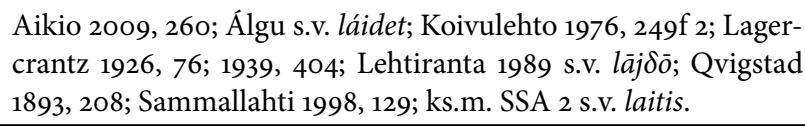 \\
\hline laampe & $\begin{array}{l}\text { Álgu s.v. laampe; Heikkilä 2014, 119, 240; Lagercrantz 1939, 399; } \\
\text { Qvigstad 1893, 204. }\end{array}$ \\
\hline laavkedh & $\begin{array}{l}\text { Álgu s.v. lávgat; Bergsland 1964, 144; Bjorvand \& Lindeman } \\
2007 \text { s.v. lagg; Lagercrantz 1939, 410; Lehtiranta } 1989 \text { s.v. lāyvę; } \\
\text { Sammallahti 1998, } 129 .\end{array}$ \\
\hline laedtie & $\begin{array}{l}\text { Aikio 2009, 26o; Álgu s.v. láddi; Lagercrantz 1939, 401; Lehti- } \\
\text { ranta } 1989 \text { s.v. lāntē; Qvigstad 1893, 205, 210; Sammallahti 1998, } \\
\text { 129; SSA } 2 \text { s.v. lanta2 }\end{array}$ \\
\hline laejjies & $\begin{array}{l}\text { Aikio 2012, 110; Álgu s.v. slaer; Qvigstad 1893, 209; Sköld 1980, } \\
\text { 108; SSA } 2 \text { s.v. laimea. }\end{array}$ \\
\hline laejpie & $\begin{array}{l}\text { Álgu s.v. hleifr; Koivulehto 2002, 592; Lagercrantz 1926, 70; 1939, } \\
\text { 4O3; LÄGLOS } 2 \text { s.v. leipä; Qvigstad 1893, 208; Sammallahti 1998, } \\
\text { 251; SSA } 2 \text { s.v. leipä. }\end{array}$ \\
\hline laejrie & $\begin{array}{l}\text { Álgu s.v. laejrie; Heikkilä 2014, 113; Lagercrantz 1939, 404; Qvig- } \\
\text { stad 1893, } 209 .\end{array}$ \\
\hline laektedh & $\begin{array}{l}\text { Aikio 2009, 191-192; Collinder 1932, 220; Lagercrantz 1939, 404- } \\
405 .\end{array}$ \\
\hline lihtse & $\begin{array}{l}\text { Aikio } 2006,15 \text {; Álgu s.v. lïhtse; Koivulehto 1999b, 8-9; Lehtiranta } \\
1989 \text { s.v. lę } \delta \text { s. }\end{array}$ \\
\hline lijnie & $\begin{array}{l}\text { Álgu s.v. lijnie; Lagercrantz 1926, 76; 1939, 422; Lehtiranta } 1989 \\
\text { s.v. lijnē; LÄGLOS } 2 \text { s.v. liina; Qvigstad 1893, 216. }\end{array}$ \\
\hline
\end{tabular}




\section{Minerva Piha}

\begin{tabular}{|c|c|}
\hline Saami word & Reference literature \\
\hline $\begin{array}{l}\text { liksie } \sim \text { livsie / } \\
\text { lievsie } \sim \text { luevsie }\end{array}$ & $\begin{array}{l}\text { Aikio 2009, 260; Àlgu s.v. lýsi; Lagercrantz 1926, 75, 76; 1939, 423; } \\
\text { Qvigstad 1893, 218. }\end{array}$ \\
\hline loeves & $\begin{array}{l}\text { Álgu s.v. luovos; Lagercrantz 1939, 452-453; Lehtiranta } 1989 \text { s.v. } \\
\text { lōvęs; Qvigstad 1893, 226; Sammallahti 1998, 129, } 252 .\end{array}$ \\
\hline luptedh & $\begin{array}{l}\text { Álgu s.v. loktet; Lagercrantz 1939, 431; Lehtiranta } 1989 \text { s.v. lopte; } \\
\text { Sammallahti 1998, 129, 252; Schalin } 2018 \text { pers.comm. }\end{array}$ \\
\hline maake & $\begin{array}{l}\text { Álgu s.v. máhka; Lagercrantz 1926, 82; 1939, 469-470; Lehtiranta } \\
1989 \text { s.v. mākẹ; Qvigstad 1893, 229; Sammallahti 1998, } 129 .\end{array}$ \\
\hline maanoe & $\begin{array}{l}\text { Álgu s.v. mánnu; Koivulehto 1999b, 20; 2002, 589; Lehtiranta } \\
1989 \text { s.v. mānō; Qvigstad 1893, 231; Sammallahti 1998, 129, 253- } \\
\text { 254. }\end{array}$ \\
\hline maarhvie & $\begin{array}{l}\text { Aikio 2006, 14; 2012, 109; Álgu s.v. márfi; Lagercrantz 1926, 82; } \\
\text { 1939, } 473 .\end{array}$ \\
\hline maelie & $\begin{array}{l}\text { Aikio 2009, 260; Álgu s.v. mál; Koivulehto 2002, 589; Lager- } \\
\text { crantz 1939, 471; Lehtiranta } 1989 \text { s.v. mālē; SSA 2, 36, } 37 \text {. }\end{array}$ \\
\hline naehpie & $\begin{array}{l}\text { Álgu s.v. náhppi; Lagercrantz 1926, 91; 1939, 516; Lehtiranta } 1989 \\
\text { s.v. nāppē; LÄGLOS 2, s.v. nappo; Qvigstad 1893, 243; Sammal- } \\
\text { lahti 1998, 129; ks.m. SSA } 2 \text { s.v. nappo. }\end{array}$ \\
\hline nejpie & $\begin{array}{l}\text { Álgu s.v. niibi; Bjorvand \& Lindeman } 2007 \text { s.v. kniv; Heikkilä } \\
\text { 2014, 112; Lagercrantz 1926, 92; 1939, 522; Lehtiranta } 1989 \text { s.v. } \\
\text { nijpē; Qvigstad 1893, 245; Sammallahti 1998, 129; Schalin } 2018 \\
\text { pers. comm. }\end{array}$ \\
\hline noerhte & $\begin{array}{l}\text { Álgu s.v. nuorti; Bjorvand \& Lindeman } 2007 \text { s.v. nord; Collinder } \\
\text { 1932, 222; Koivulehto 1988, 28; Lagercrantz 1926, 95; 1939, 535- } \\
\text { 536; Lehtiranta } 1989 \text { s.v. nōrttē; Qvigstad 1893, 248; Sammallahti } \\
\text { 1998, 129; Schalin } 2018 \text { pers. comm. }\end{array}$ \\
\hline nuehtie & $\begin{array}{l}\text { Álgu s.v. nuohtti; Koivulehto 1992a, 91; Lagercrantz 1939, 536- } \\
\text { 537; Lehtiranta } 1989 \text { s.v. nōttē; LÄGLOS } 2 \text { s.v. nuotta; Qvigstad } \\
\text { 1893, 248; Sammallahti 1998, } 129 \text {. }\end{array}$ \\
\hline plaahkoe & Aikio 2012, 111; Álgu s.v. plaahkoe; Qvigstad 1893, 210. \\
\hline plaassa & $\begin{array}{l}\text { Aikio 2012, 111; Álgu s.v. fles; Koivulehto 1999b, 14; Qvigstad } \\
\text { 1893, } 212 .\end{array}$ \\
\hline plaerie & $\begin{array}{l}\text { Koivulehto 1997b, 82; 1999a, 344; Lagercrantz 1939, 401; Qvigstad } \\
\text { 1893, 206; Sköld 1960, } 26 .\end{array}$ \\
\hline plievvies & $\begin{array}{l}\text { Aikio 2012, 110; Álgu s.v. plievvies; Lagercrantz 1939, 661; Qvig- } \\
\text { stad 1893, 110. }\end{array}$ \\
\hline provrese & $\begin{array}{l}\text { Aikio 2012, 110; Álgu s.v. brud; Koivulehto 1999b, 8; Qvigstad } \\
\text { 1893, 117. }\end{array}$ \\
\hline
\end{tabular}


Combining Proto-Scandinavian loanword strata in South Saami ...

\begin{tabular}{|c|c|}
\hline Saami word & Reference literature \\
\hline raaktse & Álgu s.v. raaktse; Koivulehto 1999b, 9; Lagercrantz 1939, 716. \\
\hline raajne & $\begin{array}{l}\text { Álgu s.v. hreinn; Lagercrantz 1926, 133; 1939, 713; LÄGLOS } 3 \text { s.v. } \\
\text { rainis; Qvigstad 1893, } 255 .\end{array}$ \\
\hline raajroe & $\begin{array}{l}\text { Aikio 2009, 272; Álgu s.v. ráidu; Koivulehto 2006, 426; Lager- } \\
\text { crantz 1939, 714; Lehtiranta } 1989 \text { s.v. rājtō; Qvigstad 1893, 255; } \\
\text { Sammallahti 1998, 129, } 261 .\end{array}$ \\
\hline raammaa & $\begin{array}{l}\text { Álgu s.v. ramas; Lagercrantz 1939, 717; Lehtiranta } 1989 \text { s.v. rẹmes; } \\
\text { Sköld 1960, } 67 .\end{array}$ \\
\hline raavke & $\begin{array}{l}\text { Aikio 2009, 272; Álgu s.v. rávga; Lagercrantz 1939, 721; Lehti- } \\
\text { ranta } 1989 \text { s.v. rāvké; LÄGLOS } 3 \text { s.v. raukka; Qvigstad 1893, 261; } \\
\text { Sammallahti 1998, } 129 .\end{array}$ \\
\hline raavre & $\begin{array}{l}\text { Aikio 2009, 272-273; Álgu s.v. rávdu; Koivulehto 1976, 34, 247; } \\
\text { Lagercrantz 1939, 721-722; Lehtiranta } 1989 \text { s.v. rāvtō; Qvigstad } \\
\text { 1893, 260; Sammallahti 1998, 129. }\end{array}$ \\
\hline raejvie & Álgu s.v. raejvie; Bergsland 1988, 162. \\
\hline rïekte / riektes & Álgu s.v. riekta; Lagercrantz 1939, 733; Sammallahti 1998, 261. \\
\hline rijsie & $\begin{array}{l}\text { Álgu s.v. rissi; Koivulehto 1999b, 14; Lagercrantz 1926, 137; 1939, } \\
\text { 729; Lehtiranta } 1989 \text { s.v. rissē; Qvigstad 1893, 266; Sammallahti } \\
\text { 1998, 129, } 261 .\end{array}$ \\
\hline råhtoe & $\begin{array}{l}\text { Aikio 2009, 275; Álgu s.v. råhtoe; Koivulehto 1971, 593; Lager- } \\
\text { crantz 1939, 738; Lehtiranta1989, s.v. rotō }\end{array}$ \\
\hline råtnoe & $\begin{array}{l}\text { Aikio } 2009 \text {, 274; Álgu s.v. råtnoe; Lagercrantz 1939, 737; Lehti- } \\
\text { ranta } 1989 \text { s.v. ronō. }\end{array}$ \\
\hline riejries & $\begin{array}{l}\text { Álgu s.v. reid; Lagercrantz 1926, 136; 1939, 723; LÄGLOS } 3 \text { s.v. } \\
\text { ratsas; Qvigstad 1893, } 279 .\end{array}$ \\
\hline roehtse & $\begin{array}{l}\text { Álgu s.v. rót; Koivulehto 1999b, 10; Lagercrantz 1939, 748; Qvig- } \\
\text { stad 1893, 276-277; Schalin } 2018 \text { pers. comm. }\end{array}$ \\
\hline rööpses & $\begin{array}{l}\text { Koivulehto 1999b, 15; Lehtiranta } 1989 \text { s.v. *rōpse ; Sammallahti } \\
\text { 1998, 128; 2001, 409. }\end{array}$ \\
\hline saajve & $\begin{array}{l}\text { Aikio 2009, 276; Álgu s.v. saajve; Korhonen 1981, 47; Lagercrantz } \\
\text { 1939, 767; Lehtiranta } 1989 \text { s.v. sāvję; Qvigstad 1893, 332; Sköld } \\
\text { 1961, 126; 1980, 108; SSA } 3 \text { s.v. saivo. }\end{array}$ \\
\hline saalje & $\begin{array}{l}\text { Álgu s.v. selja; Koivulehto 2001, 364; 2006, 428; 2016, 262; Lager- } \\
\text { crantz 1939, 769; Qvigstad 1893, 331; Schalin } 2018 \text { pers. comm. }\end{array}$ \\
\hline saavtje / saavhtse & $\begin{array}{l}\text { Álgu s.v. sávza; Heikkilä 2014, 119; Koivulehto 1999b, 8; 2002, } \\
\text { 589-590; Korhonen 1981, 180; Lehtiranta } 1989 \text { s.v. sāvce; Qvig- } \\
\text { stad 1893, 285; Sammallahti 1998, } 129 .\end{array}$ \\
\hline
\end{tabular}




\section{Minerva Piha}

\begin{tabular}{|c|c|}
\hline Saami word & Reference literature \\
\hline saedtie & $\begin{array}{l}\text { Álgu s.v. sandr; Lagercrantz 1939, 764-765; LÄGLOS } 3 \text { s.v. santa; } \\
\text { Qvigstad 1893, 281. }\end{array}$ \\
\hline saejrie & $\begin{array}{l}\text { Álgu s.v. sár; Korhonen 1981, 47; Lagercrantz 1939, 766; LÄGLOS } \\
\text { 1 s.v. haire; LÄGLOS } 3 \text { s.v. sairas; Qvigstad 1893, 284; Sköld 1980, } \\
\text { 108. }\end{array}$ \\
\hline saejtie & 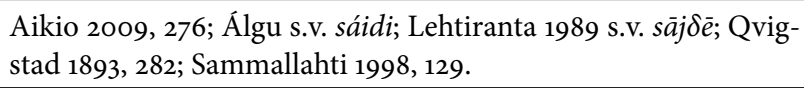 \\
\hline silpe & $\begin{array}{l}\text { Aikio 2009, 278; Álgu s.v. silba; Lagercrantz 1939, 786; Lehtiranta } \\
1989 \text { s.v. silpẹ; Qvigstad 1893, 287; Sammallahti 1998, } 129 .\end{array}$ \\
\hline skaaltjoe & $\begin{array}{l}\text { Aikio } 2006,14 ; 2012,110 ; 2009,250 ; 2012,110 ; \text { Álgu s.v. skálžu; } \\
\text { Lehtiranta } 1989 \text { s.v. kālćō; Qvigstad 1893, 290-291. }\end{array}$ \\
\hline skaavtjoe & $\begin{array}{l}\text { Aikio 2012, 110; Álgu s.v. skegg; Lagercrantz 1939, 797; Qvigstad } \\
\text { 1893, 293. }\end{array}$ \\
\hline skinne & $\begin{array}{l}\text { Aikio 2009, 253; Álgu s.v. skinne; Heikkil 2014, 119; Lagercrantz } \\
\text { 193e9, 799; Qvigstad 1893, } 294 .\end{array}$ \\
\hline skugkie & Aikio 2012, 110; Álgu s.v. skovve; Lagercrantz 1926, 150; 1939, 806. \\
\hline skuvmie & $\begin{array}{l}\text { Álgu s.v. skuvmie; Koivulehto 1992a, 93; Lagercrantz 1939, 807; } \\
\text { Sammallahti 1998, 128; Sköld 1986, 131-150. }\end{array}$ \\
\hline slikte & Aikio 2012, 110; Qvigstad 1893, 220. \\
\hline snaejrie & $\begin{array}{l}\text { Álgu s.v. snaejrie; Collinder 1932, 221-222; Qvigstad 1893, 306- } \\
\text { 307. }\end{array}$ \\
\hline staavra & $\begin{array}{l}\text { Álgu s.v. staurr; Koivulehto 1979, 279-280; 1984, 118; Lagercrantz } \\
\text { 1939, 838; LÄGLOS } 3 \text { s.v. saura1; Qvigstad 1893, } 320\end{array}$ \\
\hline staeries & $\begin{array}{l}\text { Álgu s.v. staeries; Koivulehto 1993a, 30; Lagercrantz 1939, 291; } \\
\text { Qvigstad 1893, 317; Schalin } 2018 \text { pers. comm. }\end{array}$ \\
\hline ståapoe & $\begin{array}{l}\text { Álgu s.v. stohpu; Heikkilä 2014, 240; Lagercrantz 1939, 841; Qvig- } \\
\text { stad 1893, 322; Sammallahti 1998, 263; Schalin } 2018 \text { pers. comm; } \\
\text { ks.m. SSA } 3 \text { s.v. tupa. }\end{array}$ \\
\hline suahtehke & $\begin{array}{l}\text { Álgu s.v. suohtas; Koivulehto 1999b, 18; Lehtiranta } 1989 \text { s.v. sōttę; } \\
\text { Sammallahti 1998, 129, } 264 .\end{array}$ \\
\hline sudtie & $\begin{array}{l}\text { Aikio } 2009,153 \text {; Álgu s.v. sudtie; Lehtiranta } 1989 \text { s.v. suntē; Sam- } \\
\text { mallahti 1998, } 264 \text {. }\end{array}$ \\
\hline svaajnes & Álgu s.v. sveinn; LÄGLOS 3, s.v. soini; Qvigstad 1893, 312 \\
\hline svaaloe & $\begin{array}{l}\text { Aikio 2012, 110; Álgu s.v. spálfu; Qvigstad 1893, 312; Schalin } 2018 \\
\text { pers. comm. }\end{array}$ \\
\hline svijnie & $\begin{array}{l}\text { Álgu s.v. svijnie; Heikkilä 2014, 240; Lagercrantz 1939, 833; Qvig- } \\
\text { stad 1893, 313. }\end{array}$ \\
\hline
\end{tabular}


Combining Proto-Scandinavian loanword strata in South Saami ...

\begin{tabular}{|c|c|}
\hline Saami word & Reference literature \\
\hline tjuvrie & $\begin{array}{l}\text { Koivulehto 1997a, 160; Lagercrantz 1939, 100; Lehtiranta } 1989 \text { s.v. } \\
\text { *ću } \delta \bar{e} \text {. }\end{array}$ \\
\hline toejhkoe & $\begin{array}{l}\text { Aikio 2009, 27; Álgu s.v. tík; Heikkilä 2014, 233; Koivulehto } \\
\text { 2009, 422f 13; Lagercrantz 1939, 920; Qvigstad 1893, } 335 \text {. }\end{array}$ \\
\hline vaanhtse, faahtse & $\begin{array}{l}\text { Álgu s.v. fáhcca; Koivulehto 1999b, 8; Lagercrantz 1926, 201; 1939, } \\
\text { 128; Lehtiranta } 1989 \text { s.v. vāccę; Qvigstad 1893, 147-148; Sammal- } \\
\text { lahti 1998, 128; SSA } 3 \text { s.v. vantus. }\end{array}$ \\
\hline vaarese & $\begin{array}{l}\text { Álgu s.v. vaarese; Koivulehto 1999b, 9; Lagercrantz 1939, 989; } \\
\text { Qvigstad 1893, 339. }\end{array}$ \\
\hline $\begin{array}{l}\text { vaarjoeh, } \\
\text { vaarjese }\end{array}$ & $\begin{array}{l}\text { Álgu s.v. fárju; Lagercrantz 1939, 131; Lehtiranta } 1989 \text { s.v. vārjō; } \\
\text { LÄGLOS } 3 \text { s.v. vaate; Qvigstad 1893, 145, 339; Sammallahti 1998, } \\
128 .\end{array}$ \\
\hline vaartasjidh & $\begin{array}{l}\text { Aikio 2009, 287; Álgu s.v. vaartasjidh; Koivulehto 1999b, 12; } \\
\text { Lehtiranta } 1989 \text { s.v. vārtā; Qvigstad 1893, 343; Sammallahti 1998, } \\
\text { 129. }\end{array}$ \\
\hline vaegkie & $\begin{array}{l}\text { Aikio 2009, 286; Álgu s.v. vaegkie; Heikkilä 2011, 76-77; Lager- } \\
\text { crantz 1939, 979. }\end{array}$ \\
\hline vaeltedh & $\begin{array}{l}\text { Álgu s.v. vaeltedh; Lagercrantz 1939, 983-984; Lehtiranta } 1989 \\
\text { s.v. vāltē; LÄGLOS } 3 \text { s.v. vallata; Sammallahti 1998, } 265 .\end{array}$ \\
\hline vaenie(s) & $\begin{array}{l}\text { Aikio 2009, 285; Álgu s.v. vátni; Lagercrantz 1939, 985; Lehti- } \\
\text { ranta } 1989 \text { s.v. vānē; Qvigstad 1893, 339, 342; Sammallahti 1998, } \\
\text { 129; SSA } 3 \text { s.v. vaana. }\end{array}$ \\
\hline veapsa & $\begin{array}{l}\text { Álgu s.v. vievssis; Koivulehto 1999b, 11; Lagercrantz 1939, 1008; } \\
\text { Lehtiranta } 1989 \text { s.v.vēpsēs; Qvigstad 1893, 347, 348; Sammallahti } \\
\text { 1998, 129. }\end{array}$ \\
\hline vierhtse & $\begin{array}{l}\text { Álgu s.v. vierca; Bjorvand \& Lindeman } 2007 \text { s.v. voer; Collinder } \\
\text { 1932, 222; Koivulehto 1999a, 360; 1999b, 8; Lagercrantz 1939, } \\
\text { 1008; Lehtiranta 1989 s.v. vērccé; Qvigstad 1893, 347; Sammal- } \\
\text { lahti 1998, 128, 129; 2012, 10o. }\end{array}$ \\
\hline vijries & 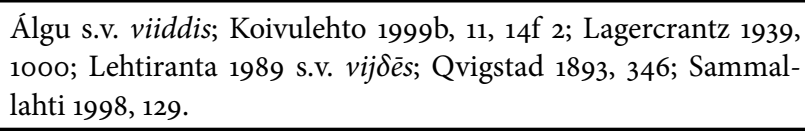 \\
\hline voevnijes & Álgu s.v. ógn; Koivulehto 1992a, 88-89; Qvigstad 1893, 352. \\
\hline vuaksa & $\begin{array}{l}\text { Heikkilä 2014, 122f 109; 240f 200; Lagercrantz 1939, 1019; Qvig- } \\
\text { stad 1893, 350. }\end{array}$ \\
\hline våhkoe & $\begin{array}{l}\text { Álgu s.v. vahkku; Lagercrantz 1939, 971; Qvigstad 1893, 340; Sam- } \\
\text { mallahti 1998, 265; ks.m SSA } 3 \text { s.v. viikko. }\end{array}$ \\
\hline$\ddot{a} w j i \varepsilon$ & Koivulehto 2008, 322; 2016, 391; Qvigstad 1893, 96. \\
\hline
\end{tabular}


Appendix 3. The reference literature for archaeological and osteological material

\begin{tabular}{|c|c|c|}
\hline $\begin{array}{l}\text { RAÄ } \\
\text { number }\end{array}$ & Archaeological site & Reference literature \\
\hline 154 & Storsjö 17:5 & Oskarsson 1998. \\
\hline 2 & Finnäset & Serning 1966a, 224; Wehlin 2016, 221. \\
\hline 112:1 & Fulufjället & Wehlin 2016, 233. \\
\hline 2 & Halvfariudden & Hemmendorff 1984; Sundström 1989c, 160. \\
\hline 80 & Hästnäset & $\begin{array}{l}\text { Gejvall 1966, 254; Hyenstarnd 1987, 132-133; } \\
\text { Serning 1962, 32, 35, 50-51; 1966a, 92-94, } \\
217-218 \text {; Wehlin 2016, 225. }\end{array}$ \\
\hline 126 & Hästudden & $\begin{array}{l}\text { Hyenstrand 1974, 109; Serning 1966a, 177- } \\
\text { 180; Wehlin 2016, } 229 \text {. }\end{array}$ \\
\hline 104 & Josvedsviken, Tomte 1:2 & Magnusson 1986, 68, 149. \\
\hline $106 \mathrm{~b}$ & Josvedsviken & Magnusson $1986,62-67$ \\
\hline 161 & Josvedsviken & Magnusson 1986, 71-73, 149. \\
\hline 10 & Klevsand & $\begin{array}{l}\text { Larje 1989; Sundström 1989a; 1989c, 158; } \\
\text { Sundström \& Feldt 1989. }\end{array}$ \\
\hline 9:1 & Krankmårtenhögen & Ambrosiani et al 1984 . \\
\hline 77 & Ljungdalen & Holm \& Willemark 1988. \\
\hline 77 & Ljungdalen & Holm \& Willemark 1988. \\
\hline 81 & Myrviken, Myre 2:1 & Magnusson $1986,76-77$ \\
\hline 9 & Näsvarpsundet & Sundström 1984; 1989c, 156. \\
\hline 36 & Präsbordet & Magnusson 1986, 88-89. \\
\hline $4: 1$ & Smalnäset & $\begin{array}{l}\text { Ambrosiani et al. 1984; Hvarfner \& Kvar- } \\
\text { ning } 1958 \text {. }\end{array}$ \\
\hline 309 & Stålavan & Sundström 1989b, 96-10o. \\
\hline 120 & Södra Getryggen & Serning 1966a, 176-177; Wehlin 2016, 228-229. \\
\hline 32 & Tjuvholmen & Magnusson 1986, 73-75. \\
\hline 6 & Vindförbergs udde & $\begin{array}{l}\text { Johansson 2016, bilaga 1; Lipping 1980; } \\
\text { Serning 1966b, 1966c; 1967. }\end{array}$ \\
\hline 163 & Ånnsjön & Jensen $1989,64-66$. \\
\hline 107 & Åssjön, Tomte 1:1, & Magnusson 1986, 69-70. \\
\hline
\end{tabular}


Combining Proto-Scandinavian loanword strata in South Saami ...

\begin{tabular}{|l|l|l|}
\hline $\begin{array}{l}\text { RAÄ } \\
\text { number }\end{array}$ & Archaeological site & Reference literature \\
\hline $14: 1$ & Örviken & $\begin{array}{l}\text { Hyenstrand 1987, 119-120; Serning 1966a, } \\
\text { 150-152; Wehlin 2016, 230-231. }\end{array}$ \\
\hline 1 & Övre Grundsjön 1 & Hemmendorff 1984. \\
\hline 7 & Övre Grundsjön 7 & Hemmendorff 1984. \\
\hline 40 & Ångron & Magnusson 1989, 89-95. \\
\hline 24 & & Hyenstrand 1972, 22 fig 15; 1974, 193 tabell 2. \\
\hline 80 & & Hyenstrand 1972, 22 fig 15; 1974, 193 tabell 2. \\
\hline 141 & & Hyenstrand 1972, 22 fig 15; 1974, 193 tabell 2. \\
\hline 21 & & Hyenstrand 1972, 22 fig 15; 1974, 193 tabell 2. \\
\hline 179 & & Hyenstrand 1972, 22 fig 15; 1974, 193 tabell 2. \\
\hline
\end{tabular}

\section{Appendix 4. (on the following pages)}

Table combining the archaeological and lexical material.

The table presents all semantic and archaeological categories, but lists lexical finds in only those semantic categories that could be detected in the archaeological material. However, all lexical finds in those categories that can be correlated with the archaeological categories of this research are provided, even if there are no corresponding archaeological find groups for all of the words. The lexical finds in the table have been classified according to their primary meaning, though some exceptions have been made due to differences in the nature of archaeological and lexical data. The secondary meanings are listed in Appendix 1 for each word if secondary meanings can be identified. 
Minerva Piha

Appendix 4. Table combining the archaeological and lexical material.

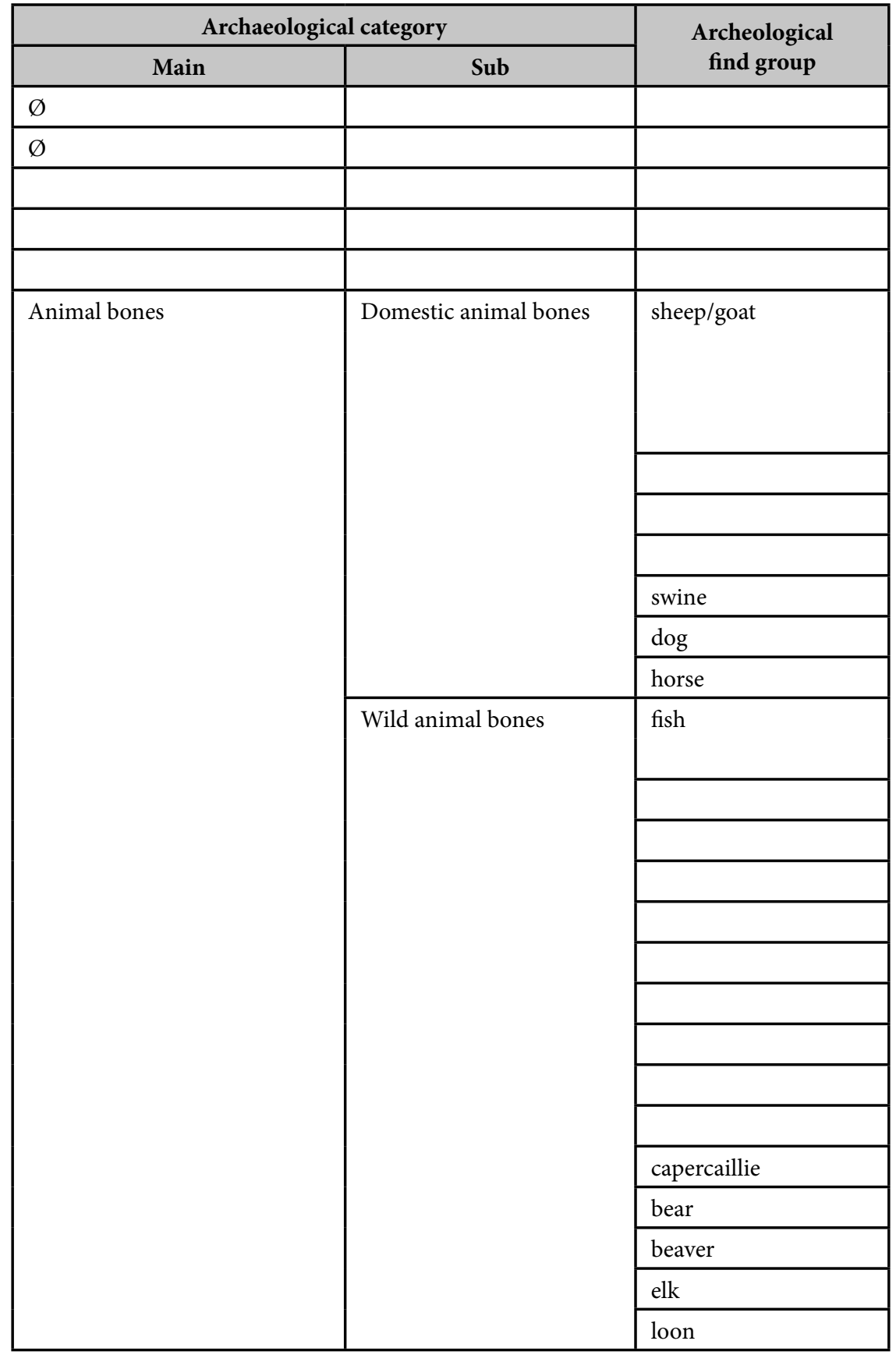


Combining Proto-Scandinavian loanword strata in South Saami ...

\begin{tabular}{|c|c|c|}
\hline \multirow{2}{*}{ Lexical find } & \multicolumn{2}{|c|}{ Semantic category } \\
\hline & Sub & Main \\
\hline & & Action processes (verbs) \\
\hline & & Adjectives \\
\hline aegnieh 'chaff, husk' & \multirow[t]{2}{*}{ Agriculture } & \multirow{12}{*}{$\begin{array}{l}\text { Agriculture and } \\
\text { domestic } \\
\text { husbandry }\end{array}$} \\
\hline hiessjie 'hay rack' & & \\
\hline svaajnes 'farm worker' & Professions related to agriculture & \\
\hline gaajhtse 'goat' & \multirow[t]{9}{*}{ Domestic animals } & \\
\hline laampe 'lamb' & & \\
\hline saavtje / saavtse 'sheep' & & \\
\hline vierhtse 'ram' & & \\
\hline gaelpie 'calf of a cow' & & \\
\hline govse 'cow' & & \\
\hline vuaksa 'ox' & & \\
\hline svijnie 'swine' & & \\
\hline täjhkoe 'dog' & & \\
\hline raavre 'red char' & \multirow[t]{2}{*}{ Fish } & \multirow[t]{15}{*}{ Wild animals } \\
\hline saejtie 'coalfish' & & \\
\hline faala / faelies 'whale' & \multirow[t]{2}{*}{ Other marine animals } & \\
\hline skaaltjoe 'seashell' & & \\
\hline aarhtse 'eagle' & \multirow[t]{4}{*}{ Birds } & \\
\hline haepkie 'falcon' & & \\
\hline raejvie 'a bird's nest on tree' & & \\
\hline svaaloe 'swallow' & & \\
\hline klahtje 'horsefly' & \multirow[t]{3}{*}{ Insects } & \\
\hline laaffa 'flea' & & \\
\hline veapsa 'wasp' & & \\
\hline & & \\
\hline & & \\
\hline & & \\
\hline & & \\
\hline
\end{tabular}


Minerva Piha

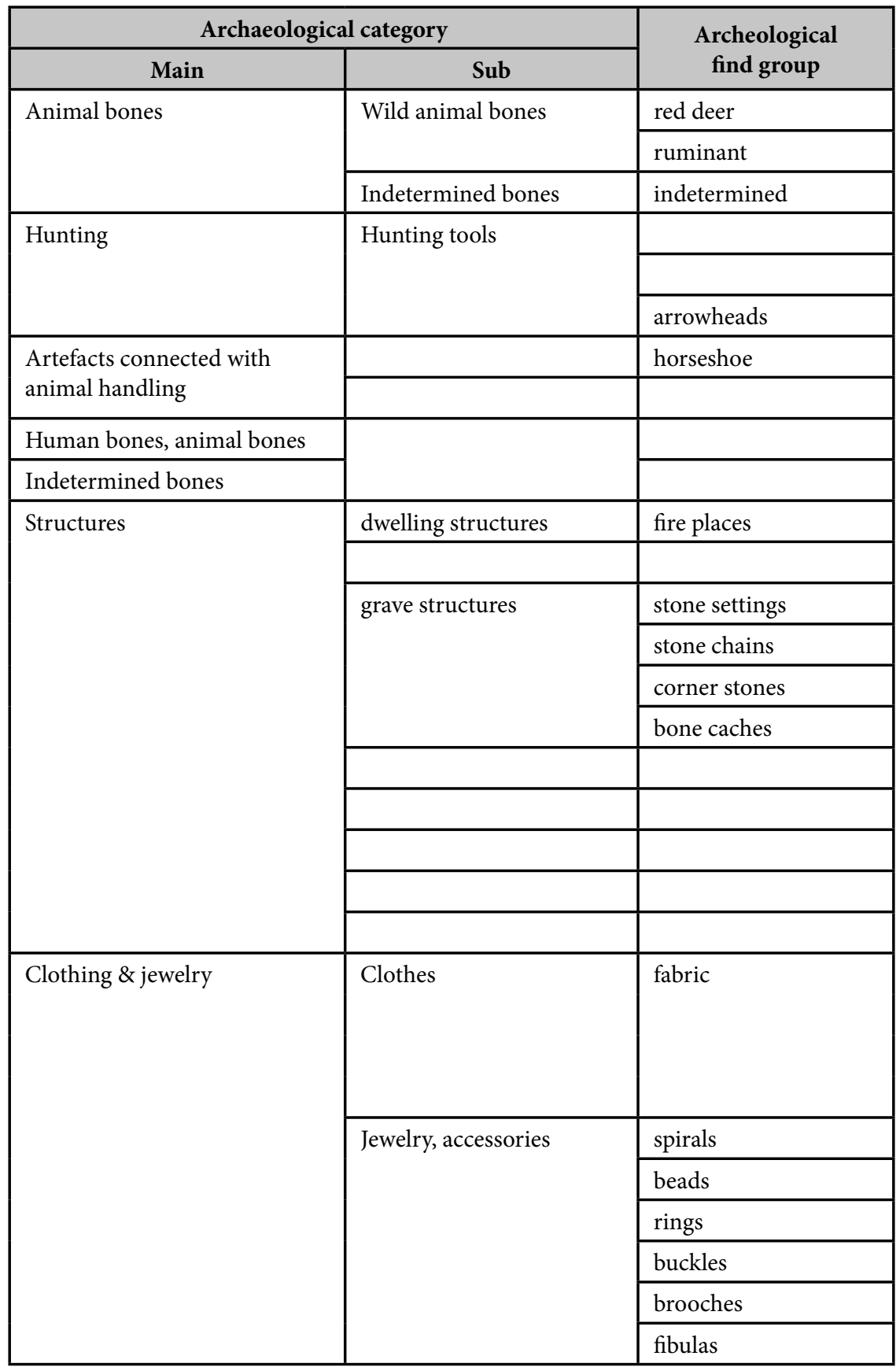


Combining Proto-Scandinavian loanword strata in South Saami ...

\begin{tabular}{|c|c|c|}
\hline \multirow{2}{*}{ Lexical find } & \multicolumn{2}{|c|}{ Semantic category } \\
\hline & Sub & Main \\
\hline & & Wild animals \\
\hline nuehtie 'seine net' & \multirow[t]{2}{*}{ Hunting and fishing tools } & \multirow[t]{2}{*}{ Hunting and fishing } \\
\hline staavra 'pole, fishing rod' & & \\
\hline & & \multirow[t]{2}{*}{ Animal handling } \\
\hline \multirow[t]{2}{*}{ naehpie 'milking bowl' } & & \\
\hline & & Body parts \\
\hline aernie 'fire grate' & \multirow[t]{2}{*}{ fireplaces } & \multirow{9}{*}{$\begin{array}{l}\text { Buildings \& } \\
\text { constructions }\end{array}$} \\
\hline aassjoe 'hearth in a smithy' & & \\
\hline & & \\
\hline & & \\
\hline buvrie 'storage building' & \multirow[t]{2}{*}{ buildings } & \\
\hline ståapoe 'house, hut' & & \\
\hline$\grave{a}^{a+h} k u_{u}$ 'chest' & \multirow[t]{3}{*}{ Other constructions } & \\
\hline nåarvie 'cross-bar' & & \\
\hline raammaa 'frame' & & \\
\hline lijnie 'shawl' & \multirow[t]{3}{*}{ Pieces of clothing } & \multirow[t]{9}{*}{ Clothing } \\
\hline vaanhtse 'mitten' & & \\
\hline vaarjoeh 'clothes' & & \\
\hline vaarese 'homespun fabric' & \multirow[t]{6}{*}{ Fabric } & \\
\hline & & \\
\hline & & \\
\hline & & \\
\hline & & \\
\hline & & \\
\hline
\end{tabular}


Minerva Piha

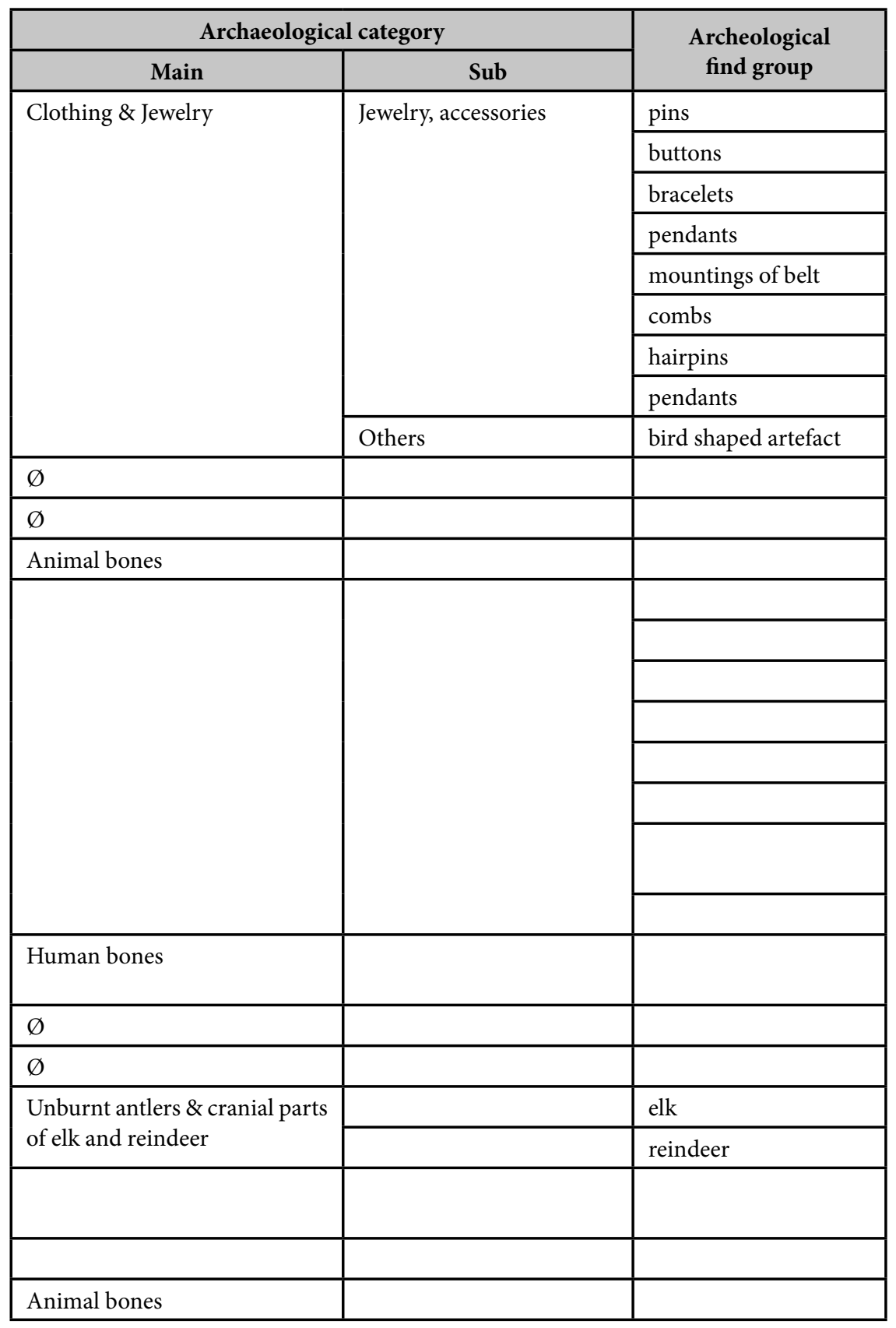


Combining Proto-Scandinavian loanword strata in South Saami ...

\begin{tabular}{|c|c|c|}
\hline \multirow{2}{*}{ Lexical find } & \multicolumn{2}{|c|}{ Semantic category } \\
\hline & Sub & Main \\
\hline & & \multirow[t]{6}{*}{ Clothing } \\
\hline & & \\
\hline & & \\
\hline & & \\
\hline & & \\
\hline & & \\
\hline & & Conditions \& changes \\
\hline & & Flora \\
\hline bearkoe 'meat for food' & \multirow[t]{7}{*}{ Food } & \multirow[t]{9}{*}{ Food \& cookery } \\
\hline laejpie 'bread' & & \\
\hline maelie 'animal blood for food' & & \\
\hline snaejrie 'slice of bread' & & \\
\hline daajje 'dough' & & \\
\hline gaahkoe 'unleavened bread' & & \\
\hline kraavhtse 'porridge' & & \\
\hline $\begin{array}{l}\text { aevlerge 'the pole in Saami } \\
\text { tent that holds the pot' }\end{array}$ & \multirow[t]{2}{*}{ Cookery } & \\
\hline \multirow[t]{4}{*}{ gaerie 'bowl' } & & \\
\hline & & $\begin{array}{l}\text { Humans \& humans as } \\
\text { members of society }\end{array}$ \\
\hline & & Natural phenomena \\
\hline & & Other words \\
\hline \multirow{2}{*}{$\begin{array}{l}\text { aevsie 'cranial parts of reindeer } \\
\text { /elk around antlers' }\end{array}$} & Elk & Wild animals \\
\hline & \multirow[t]{4}{*}{ Reindeer } & \multirow{4}{*}{$\begin{array}{l}\text { Reindeer \& reindeer } \\
\text { husbandry }\end{array}$} \\
\hline $\begin{array}{l}\text { eajma 'reindeer doe who wan- } \\
\text { ders where it wants' }\end{array}$ & & \\
\hline haame 'antler-less reindeer' & & \\
\hline råtnoe 'reindeer doe' & & \\
\hline
\end{tabular}


Minerva Piha

\begin{tabular}{|c|c|c|}
\hline \multicolumn{2}{|c|}{ Archaeological category } & \multirow{2}{*}{$\begin{array}{l}\text { Archeological } \\
\text { find group }\end{array}$} \\
\hline Main & Sub & \\
\hline & & \\
\hline & & \\
\hline & & \\
\hline & & \\
\hline \multicolumn{3}{|l|}{$\varnothing$} \\
\hline \multirow[t]{2}{*}{ Structures } & grave structures & \\
\hline & & \\
\hline & & \\
\hline & & \\
\hline \multicolumn{3}{|l|}{$\varnothing$} \\
\hline \multicolumn{3}{|l|}{$\varnothing$} \\
\hline \multicolumn{3}{|l|}{$\varnothing$} \\
\hline \multirow[t]{7}{*}{ Iron manufacture \& forging } & \multirow[t]{4}{*}{ Structures } & furnaces \\
\hline & & charring pits \\
\hline & & iron ore storages \\
\hline & & slag dumps \\
\hline & \multirow[t]{3}{*}{ Tools } & iron bars \\
\hline & & iron hammer \\
\hline & & pliers \\
\hline \multirow[t]{5}{*}{ Tools, working materials } & \multirow[t]{4}{*}{ Working material } & sheet metal \\
\hline & & iron bars \\
\hline & & \\
\hline & & \\
\hline & & \\
\hline
\end{tabular}


Combining Proto-Scandinavian loanword strata in South Saami ...

\begin{tabular}{|c|c|c|}
\hline \multirow{2}{*}{ Lexical find } & \multicolumn{2}{|c|}{ Semantic category } \\
\hline & Sub & Main \\
\hline deemedh 'to tame a reindeer' & \multirow[t]{4}{*}{ Reindeer husbandry } & \multirow{4}{*}{$\begin{array}{l}\text { Reindeer \& reindeer } \\
\text { husbandry }\end{array}$} \\
\hline gaertie 'reindeer corral' & & \\
\hline krievvie 'reindeer herd' & & \\
\hline \multirow[t]{2}{*}{ raajroe 'reindeer caravan' } & & \\
\hline & & $\begin{array}{l}\text { Relations in } \\
\text { space and time }\end{array}$ \\
\hline aajmoe 'the other world' & & \multirow[t]{5}{*}{ Religions \& beliefs } \\
\hline $\begin{array}{l}\text { saajve 'a mythical creature } \\
\text { living inside mountains' }\end{array}$ & & \\
\hline aejlege / aejlies 'holiday, Sunday' & & \\
\hline raavke 'apparition' & & \\
\hline \multirow[t]{4}{*}{ faastoe 'lent' } & & \\
\hline & & Terrain \& landscapes \\
\hline & & Vehicles \& traveling \\
\hline & & $\begin{array}{l}\text { Water \& water sys- } \\
\text { tems }\end{array}$ \\
\hline & & \multirow[t]{10}{*}{ Work-related words } \\
\hline & & \\
\hline & & \\
\hline & & \\
\hline & \multirow{5}{*}{ Working material } & \\
\hline staavra 'pole, bar' & & \\
\hline silpe 'silver' & & \\
\hline $\begin{array}{l}\text { liksie / livsie / lievsie / luevsie } \\
\text { 'blubber oil' }\end{array}$ & & \\
\hline fealloe 'plank, board' & & \\
\hline $\begin{array}{l}\text { aalhtedh 'to prepare; to } \\
\text { work with animal skin' }\end{array}$ & working & \\
\hline
\end{tabular}


Minerva Piha

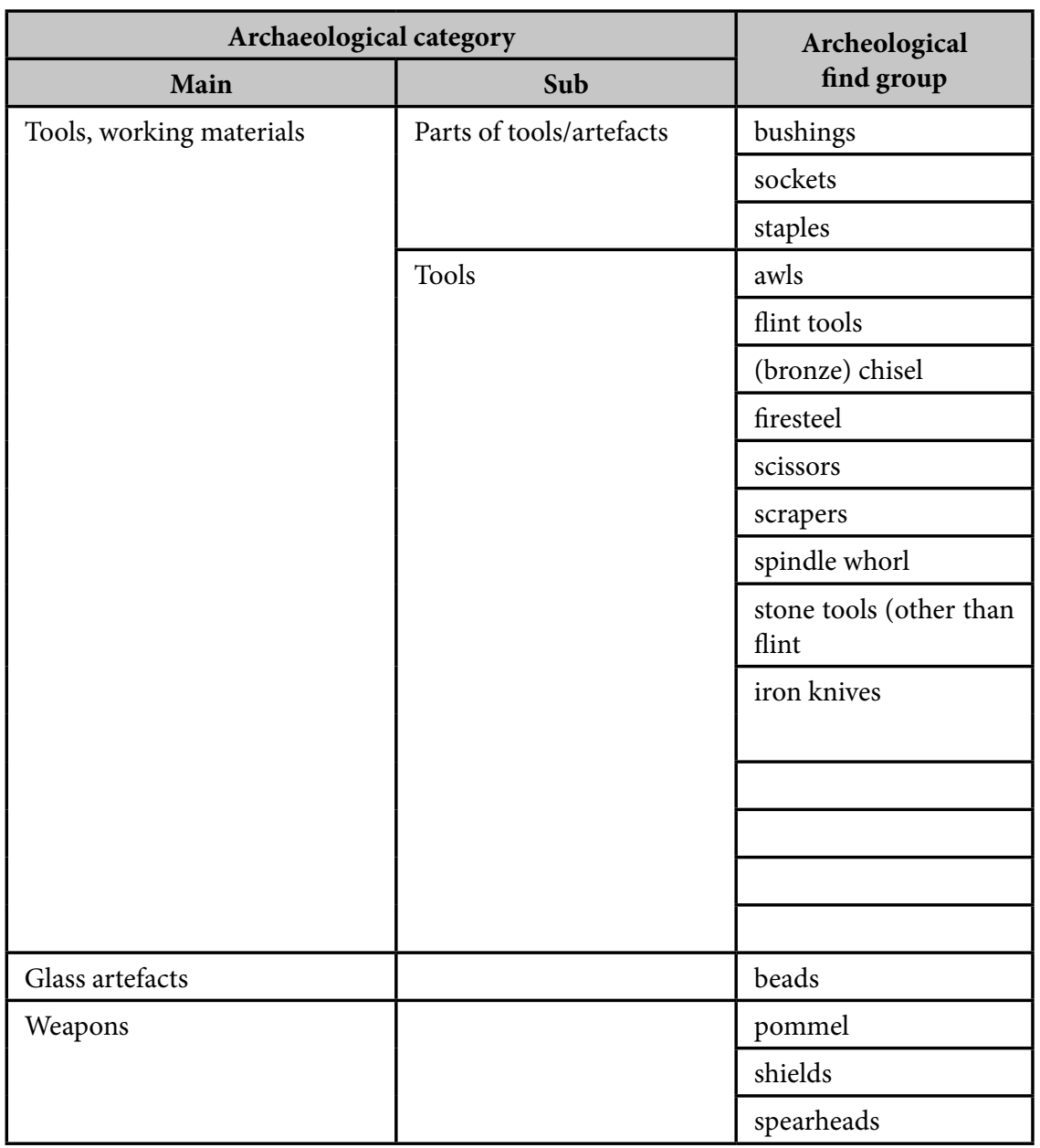


